$$
\text { جامعة الأزهر }
$$

كلية الدعوة الإنسلامية بالقاهرة

قسم الثقافة الإسلامية

$$
\begin{aligned}
& \text { لغة الجسد بين الإسلام و الدر اسات التنموية } \\
& \text { البشربة الإنة } \\
& \text { و أثز ها على المدعـو }
\end{aligned}
$$

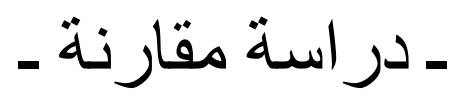

$$
\begin{aligned}
& \text { إعـداد } \\
& \text { د/ محمود رشاد محمد إعد } \\
& \text { المدرس بالقستـم }
\end{aligned}
$$


لغة الجسد بين الإسلام والدراسات التنموية البشرية وأثرها على المدعو

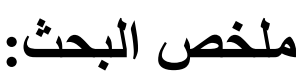

يقارن هذا البحث بين الإسلام و الدر اسات التنموية فيما يتعلق بلغة البة

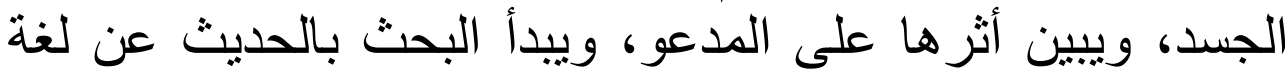

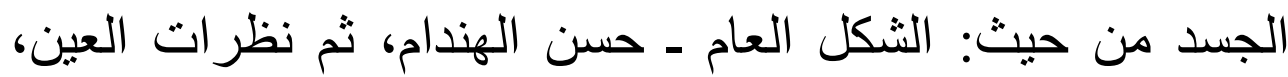

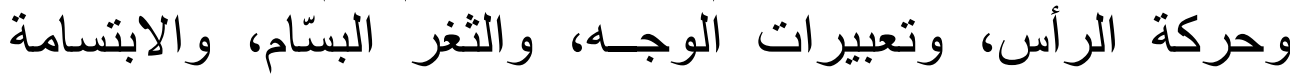

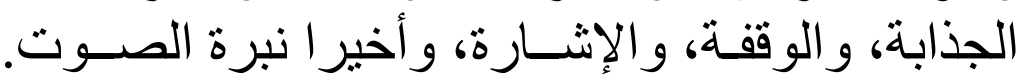

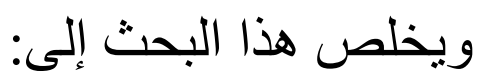

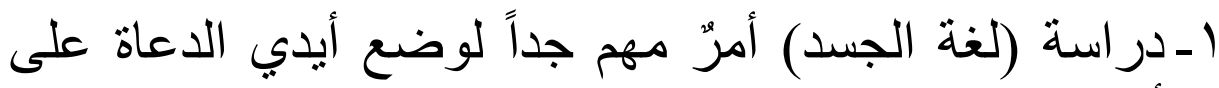
أحد المؤثرات المهمة التي قد يغفل البعض التهر عنها.

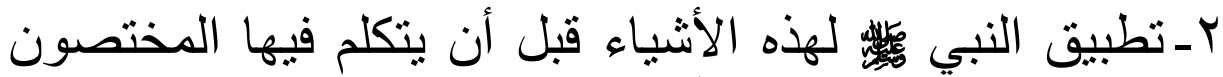

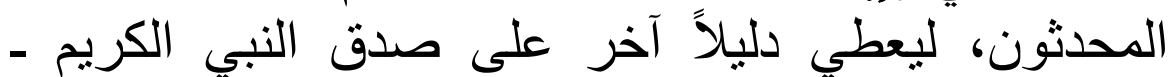
صلوات ربي وسلامه عليه -.

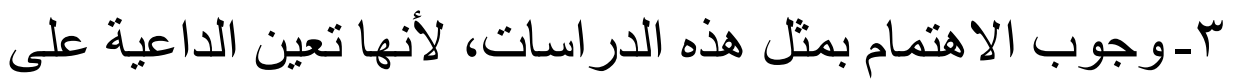

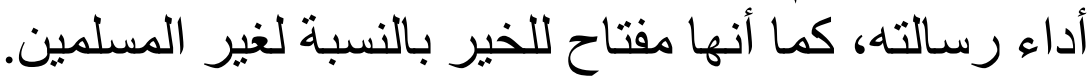

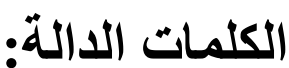
لغة_الجسد_الإسلام_الار اسات_التنمية_أثر-المدعو 
لغة الجسد بين الإسلام والدراسات التنموية البشرية وأثرها على المدعو

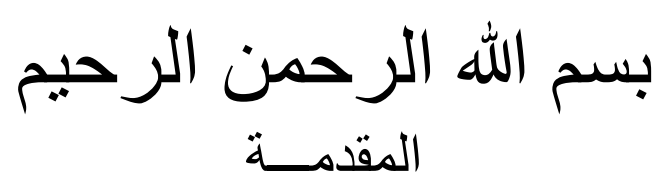

الحمد لله رب العالمين والعاقبة للمتقين ولا عدوان إلا على الظالمين الآثمين، والصلاة والسلام الأتمان الأكملان على سيدنا محمد وعلى آله وصحبه وسلم.

\section{وبعـد ؛؛؛}

فإن المتأمل في ساحة الدعوة إلى الله، يجُُ بعض الدعاة يجيدون الخطبة إعداداً

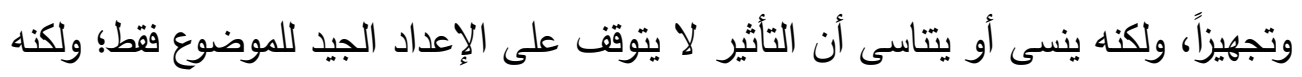

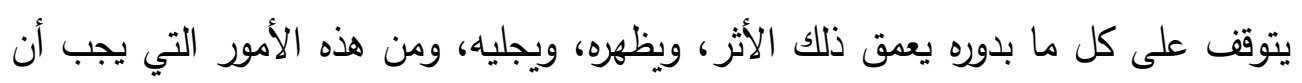

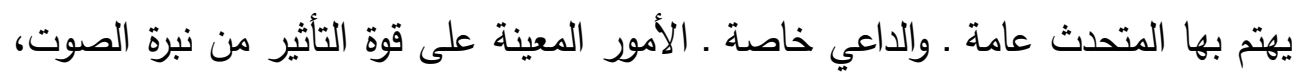

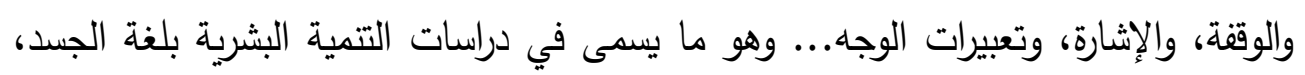
وترجع أهمية هذا الموضوع لأمور عدة منها:

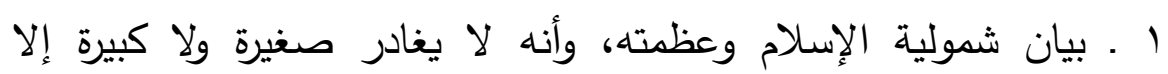
أحصاها، فهذا الموضوع يتثدق به علماء التتمية البشرية الغربية، ويزعمون أنهم

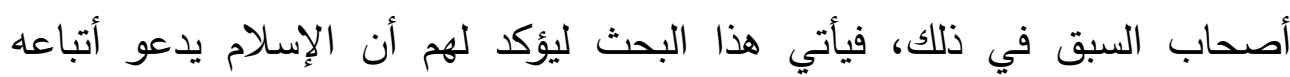

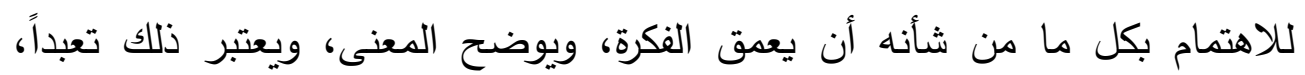

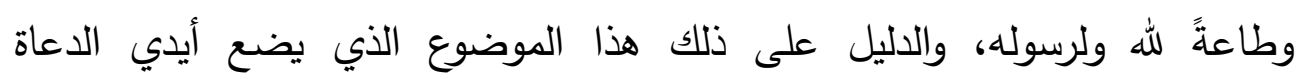
والمتحدثين على الخطوات الصحيحة للأشياء الظاهرة التي تكمل الفكرة الباطنة.

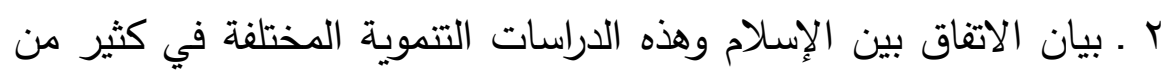

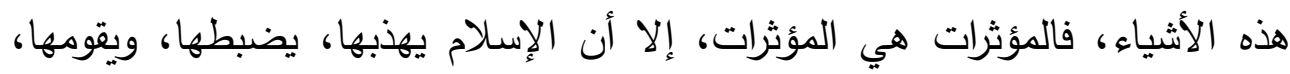

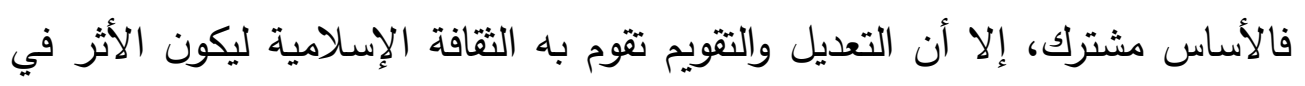


لغة الجسد بين الإسلام والدراسات التنموية البشرية وأثرها على المدعو

r ـ محاولة الإحاطة بهذه الموضوعات من جوانبها المتعددة، لتكون الفائدة

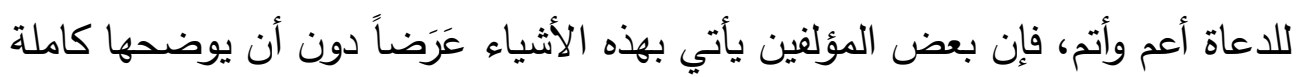

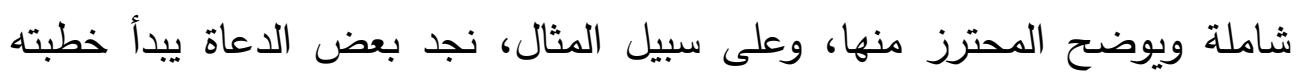

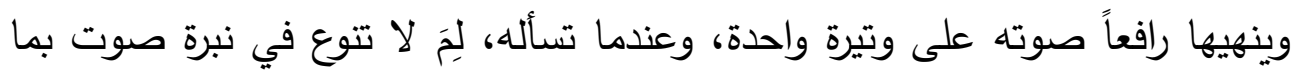

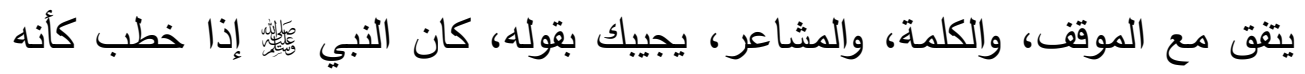
منذر جيش، وللأسف إجابته هذه تدل على: 1 العدم الأمانة العلمية في النقل.

r ب بتر المعلومة دون توضيحها شاملة كاملة. r ـ ظلم هذا الداعي لهذه الدراسات الدعوية الدفيدة.

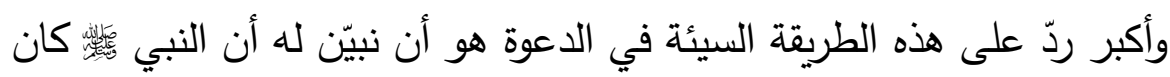

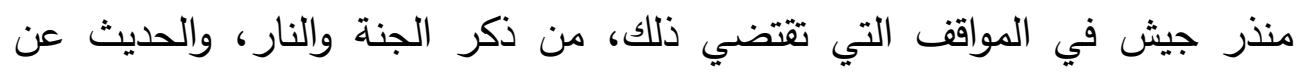

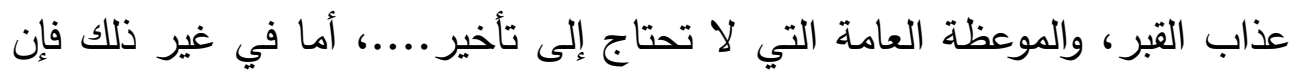
السنة شاهدة على تغيير نبرة رسول الله بحسب مقتضى المقام، وهذا ما يتضح في التي

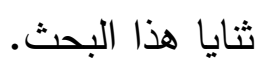

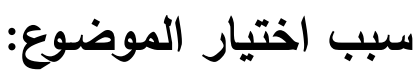

ويرجع سبب اختيار الموضوع لأمور عدة منها:

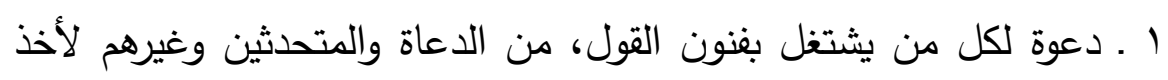

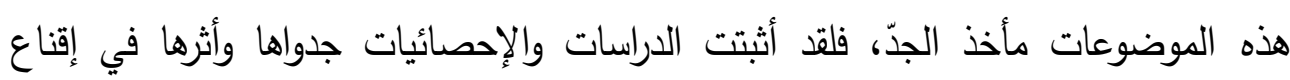
المستمح.

r ـ ت تبيه الغافلين من المتحدثين إلى الإعراض عن بعض الأمور الفرعية

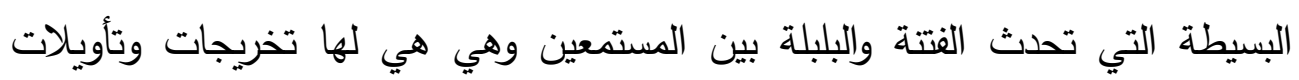


لغة الجسد بين الإسلام والدراسات التنموية البشرية وأثرها على المدعو

صالحة في الثرع مثل طول الثياب وقصره- وهذا ما سيتضح في ثنايا البحث إن شاء الله-. r ـ بيان أن القسمات المشتركة بين الثقافات هو نوع من التلاقح الثقافي،

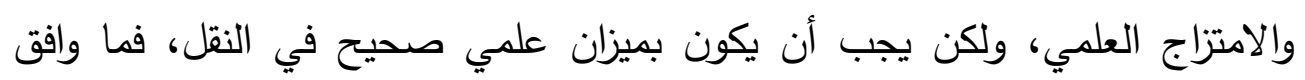

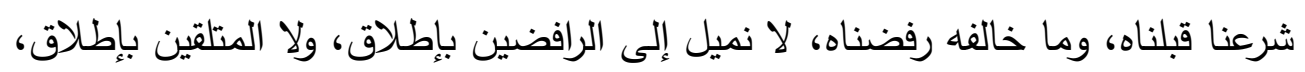

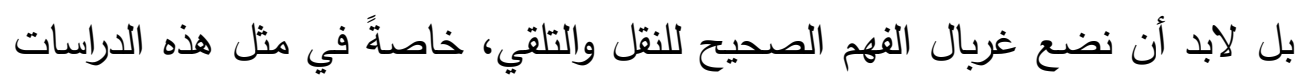
الإنسانية المشتركة.

\section{طريقة البحث:}

$$
\text { سلكت في هذا البحث ما يلي: }
$$

ا ـ مراعاة الحيدة العلمية في البحث، خاصة في الأمور التي فيها مقارنات. r ـ الحرص على الأمانة العلمية وعزو كل نصٍ إلى قائله.

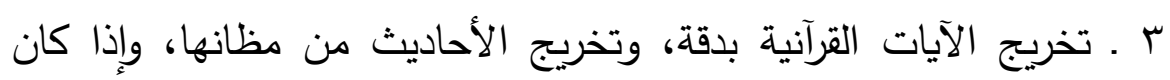
الحديث في الصحيحين ذكرت رقم الحديث وبابه وكتابه، وإذا كان في غيرهما زدت الآن عملاً آخر وهو الحكم عليه وبيان درجته.

ع . توضيح الكلمات الغامضة سواء كانت في آية أو حديث أو أثرٍ أو نصٍ... ليكون المعنى واضحاً. ه ـ توضيح عنوان البحث توضيحاً ينفي الجهالة بمقصوده ودلالته. خطة البحث: يتكون البحث من مقدمة وتمهيد وفصلٍ واحٍٍ وخاتمة. فأما المقدمة، فذكرت فيها عناصر الsقدمة العلمية. وأما التمهيد، فقتت فيه بتوضيح عنوان البحث، ومصطلحاته. 
لغة الجسد بين الإسلام والدراسات التنموية البشرية وأثرها على المدعو

وأمّا لبّ البحث فيتكون من المباحث التالية: المبحث الأول: الثكل العام ـ حسن الهندام.

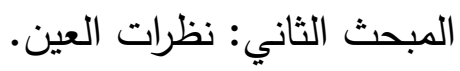
المبحث الثالث: مركة الرأس.

$$
\text { المبحث الرابع: تعبيرات الوجهـ. }
$$

المبحث الخامس: الثغر البسّام ـ الابتسامة الجذابة ..

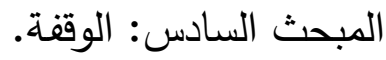

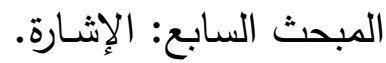

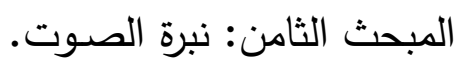

ثم تأتي الخاتمة وفيها أهم النتائج والتوصيات، ثم يأتي ثبت المصادر

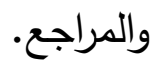

والحمد لله أولاً وأخراً وصل اللهم وسلم وبارك على سيدنا محمد وعلى آله

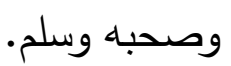


لغة الجسد بين الإسلام والدراسات التنموية البشرية و أثرها على المدعو

التمهيــــ

التعريف بمصطلح البحث من أهم خطوات البحث العلمي لتحديد المفهوم، وإخراج المتثابهات، وتعيين المراد ومصطلح هذا البحث هو ترجمة للمصطلح Body ( الإنجليزي المستخدم في دراسات التتمية البشرية المشتهر والمتعارف عليه

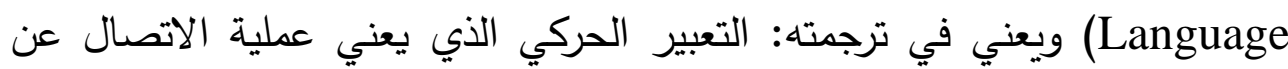

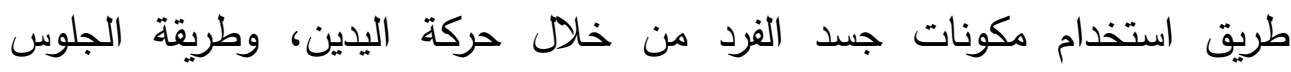
والإيماءات أو من خلال التعبير الحسي عن طريق احمرار الوجه والرعشة والتشنج

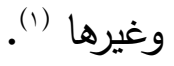

وقد دلت الدراسات التتموية المختلفة على نفس المعنى ولكن بمفهوم آخر هو الاتصال غير اللفظي NoN - Verbal Behavior . والذي يعني ( عملية نقل شعور وأحاسيس الفرد للآخرين حول حالته النفسية عن طريق الصمت أو التعبير الحركي أو عن طريق الإعراض عنهم أو الابتعاد والاقتراب منهم) (r).

فالمقصود بالمفاهيم السابقة الدلالة على أن شكل المتحدث وحركاته، وإثارته،

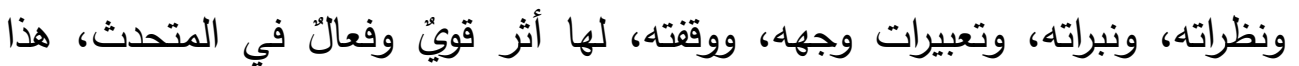

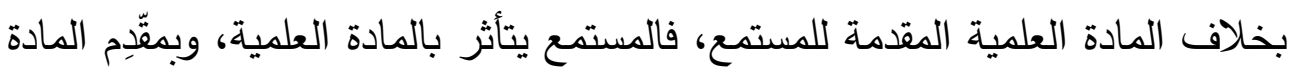

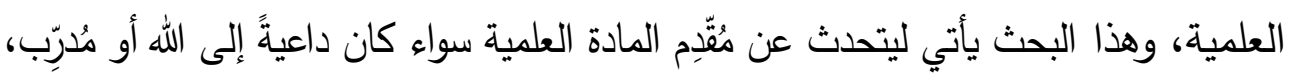
أو مُدرس.

ويأتي هذا البحث ليبين أثر مظهر الداعية، وحركاته، وتعبيرات وجهاه،

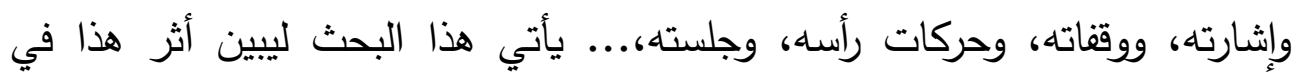

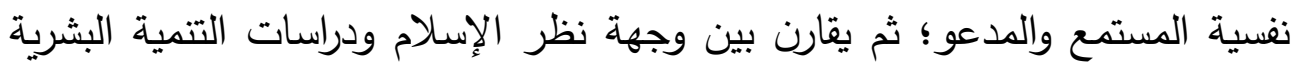


لغة الجسد بين الإسلام والدراسات التنموية البشرية و أثرها على المدعو

في ذلك.

ويمكن القول: إن مصطلح لغة الجسد أو التعبير الحركي، أو الاتصال غير

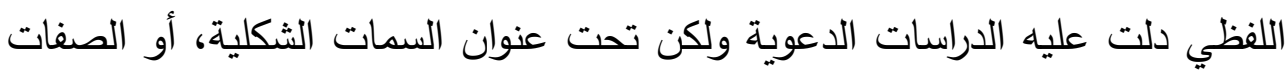
الخارجية، ولكنها خصصت في الغالب الدراسة عن مظهر الداعية أو شكله؛ ولكن هذا

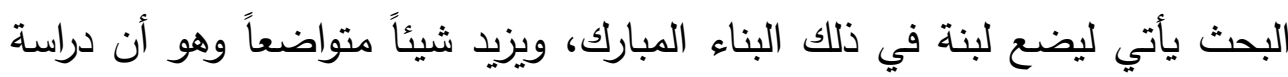
السمات الشكلية أو الخارجية ليست بمنأى عن حركة الرأس أو نظرة العين أو نبرة الصوت أو تعبيرات الوجه أو غير ذلك؛ فهي مقدمات وضرورات لابد منها في الإقناع.

لذا يمكن تعريف عنوان البحث بأنه: (الأثر النفسي الذي تحدثه مكونات جسد

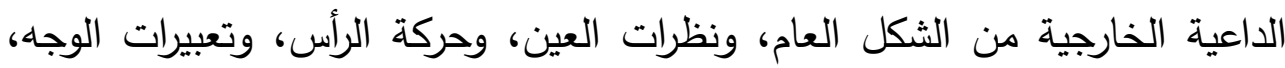

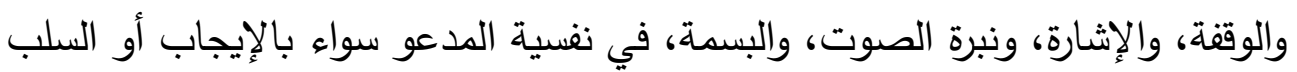

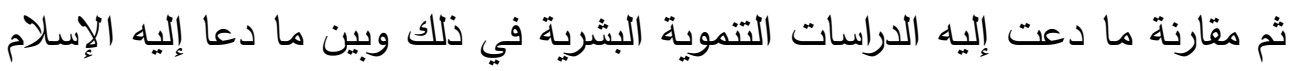

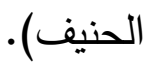


لغة الجسد بين الإسلام والدراسات التنموية البشرية و أثرها على المدعو

\section{المبحث الأول}

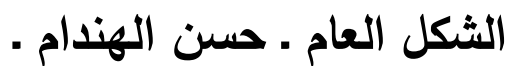

يقرر علماء التتمية البشرية حقيقة مهمة وهي أن: جمال مظهر المتحدث

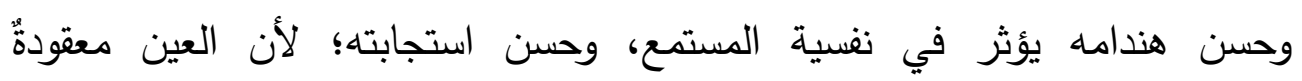

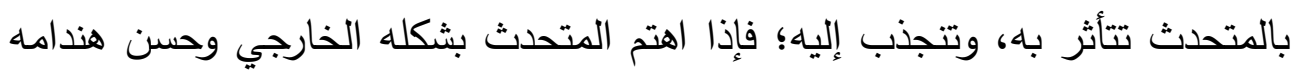

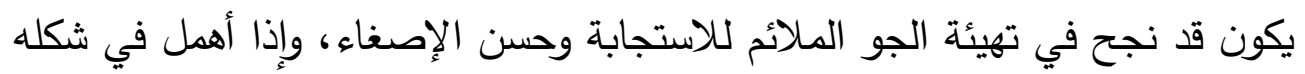

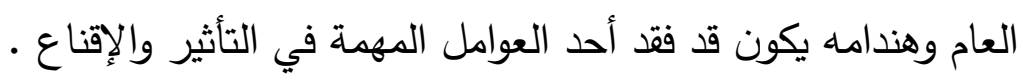

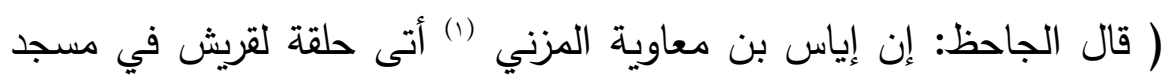

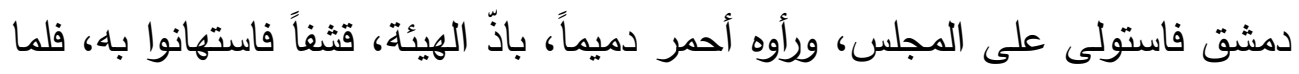
عرفوه اعتذروا إليه، وقالوا الذنب مقسوم بيننا وبينك، أتيتنا في زي مسكين تكلمنا بكلام

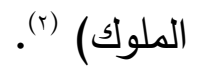

وينصح علماء التنمية البشرية الداعي والخطيب والمتحدث بالاهتمام بالمظهر

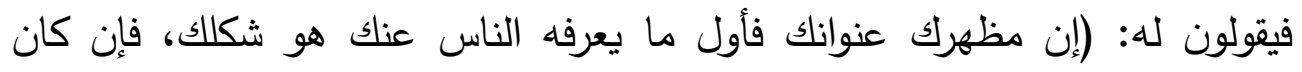

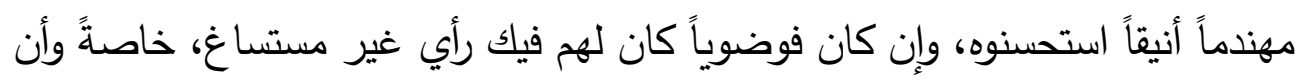

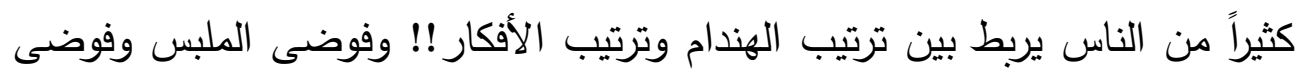

(1) هو إياس بن معاوية بن قرة المزني، من مزينة مضر ، ولاه عمر بن عبد العزيز قضاء البصرة، وكان صادق الباق

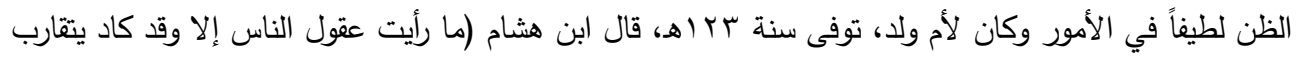

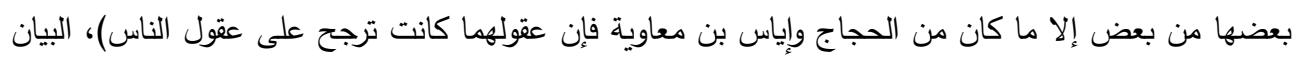

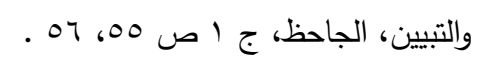

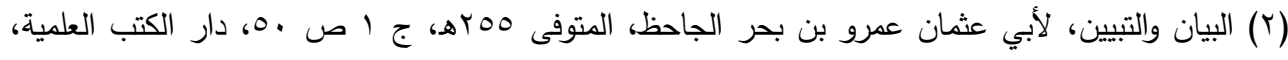


لغة الجسد بين الإسلام والدراسات التنموية البشرية و أثرها على المدعو

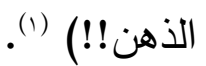

(لقد أرسل عالم نفساني إلى مجموعة كبيرة من الخطباء وسألهم عن تأثير

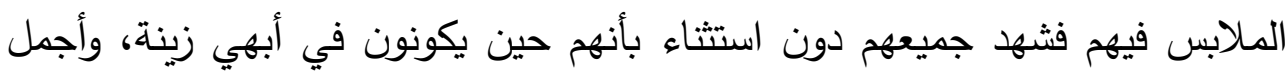
ملبس، ويعرفون ذلك ويحسونه، فإنهم يملكون زمام أنفسهم ولا يخطئون) ((). هذا الأثر الطيب من التأثير في نفوس المستمعين نتيجة حسن الهندام كأحد

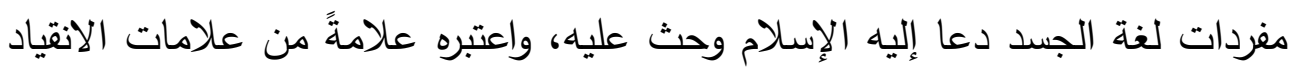

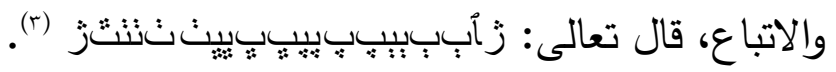

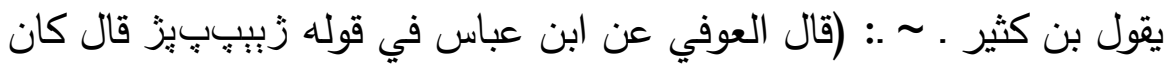

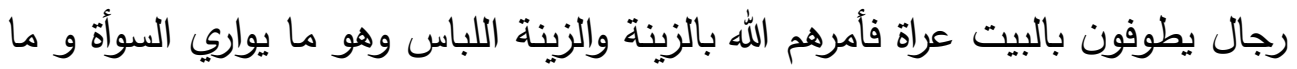

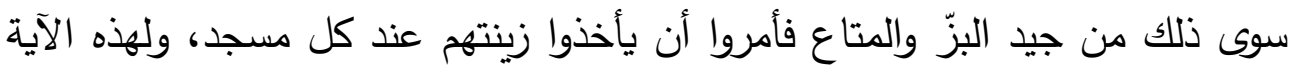
وما ورد في معناها من السنة يستحب التجمل عند الصلاة لاسيما يوم الجمعة ويوم

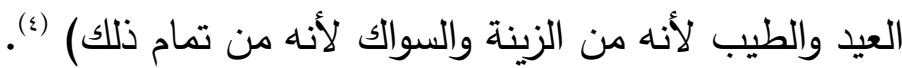
فالجمال مطلب فطري، فالنفس تحبه، والعين تألفه، والروح تهفو إليه، وفي أي شكل تبدي الجمال تجد له جمهوراً من أصحاب النفوس الطيبة، والفطر السليمة.

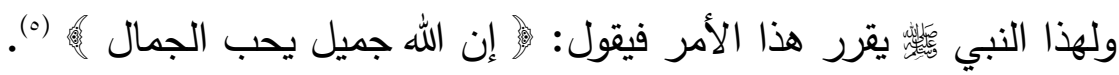

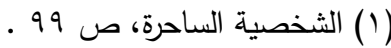

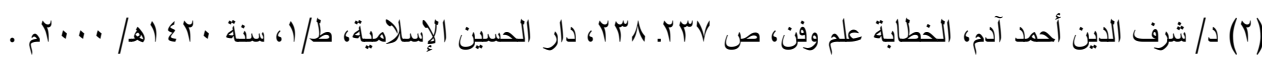

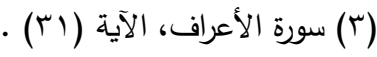

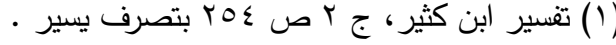

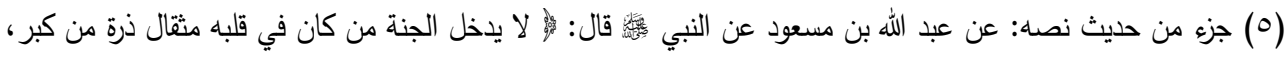
قال رجل: إن الرجل يجب أن يكون ثوبه حسناً ونعله حسناً قال: إن الله جميل يحب الجمال الكبر بطر الحق وَغْطُ الناس لهن

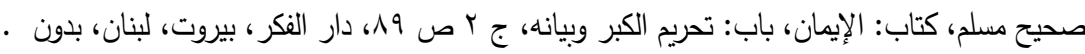


لغة الجسد بين الإسلام والدراسات التنموية البشرية و أثرها على المدعو

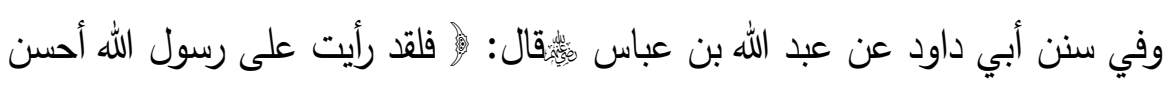

ما يكون من الحلل (1)

وحسن المظهر يقتضي كذلك أن يهتم الإنسان بشعره ورائحته ونظافته، فعن

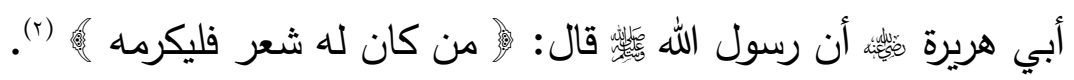

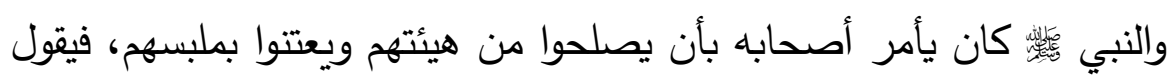

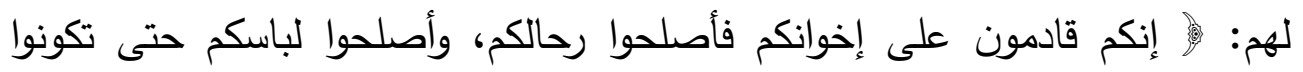

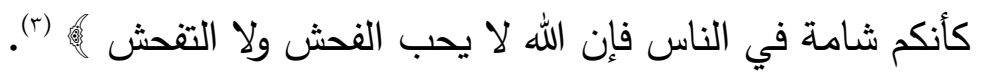
وعن عطاء بن يسار قال: ولغ فلخل رجل ثائر الرأس واللحية، فأشار إليه رسول

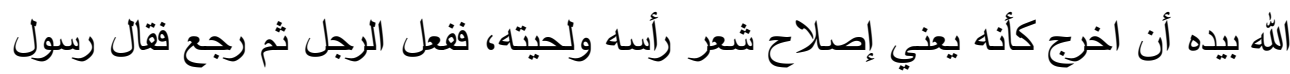
الله فتشبيه النبي والذي لا يتقق مع مبادئ الإسلام العامة.

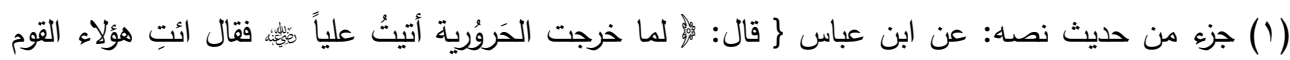

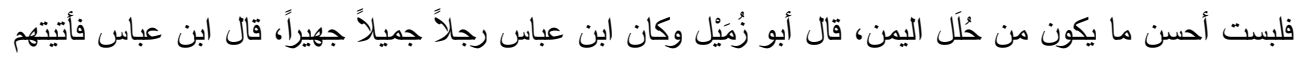

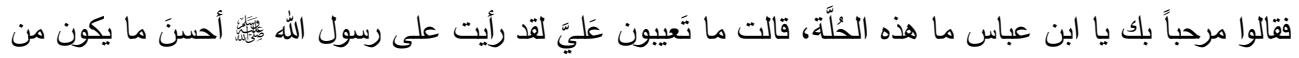

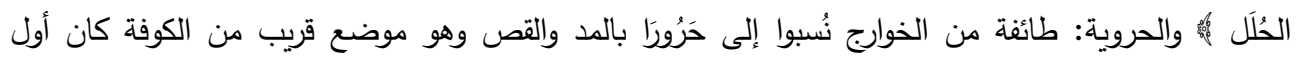

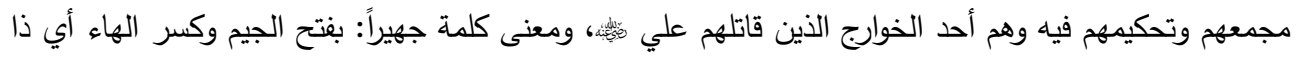

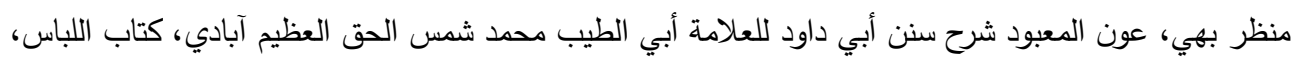

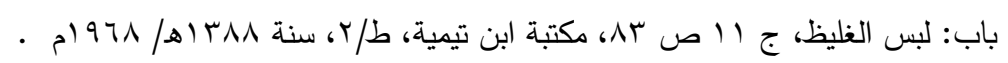

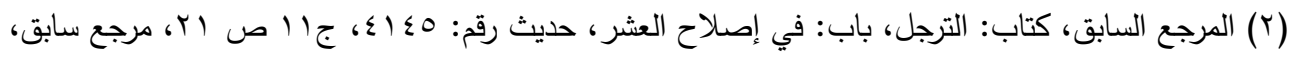
وهو صحيح (ז) سنن أبي داود، كتاب: اللباس، باب: ما جاء في إسبال الإزار ، وقال صحيح الإسناد .

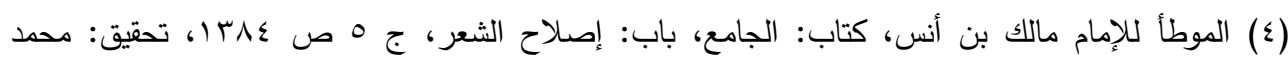

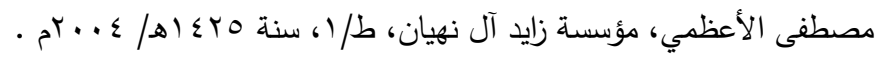


لغة الجسد بين الإسلام والدراسات التنموية البشرية و أثرها على المدعو

والرائحة الزكية الطيبة تكمّل ذلك الجمال الخارجي، وأكبر دليل على ذلك أن النبي

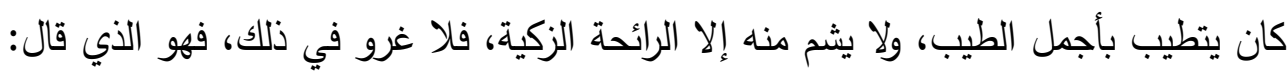

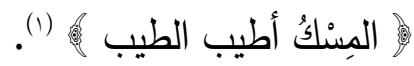

فالطامح في كسب قلوب الناس المقتفي لأثر سيد المرسلين فئس يجب أن يدرك أن اللباس يؤثر في نفسية لابسه ورائيه بشكل يدفع الاهتمام به.

يقول الثوكاني . : (إن الأعمال بالنيات، فليس المنخفض من الثياب تواضعاً وكُشْراً لثورة النفس التي لا يؤمن عليها من التكبر، إن لبس غالي الثياب من الدقاصد الصالحة

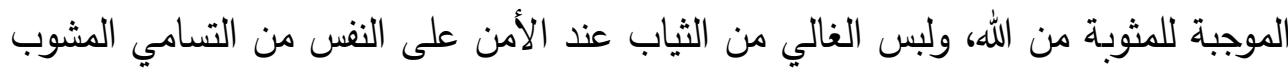

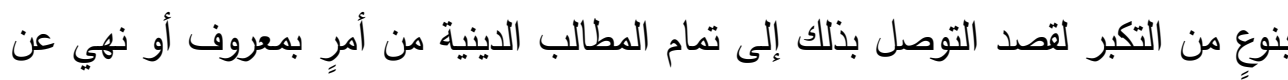

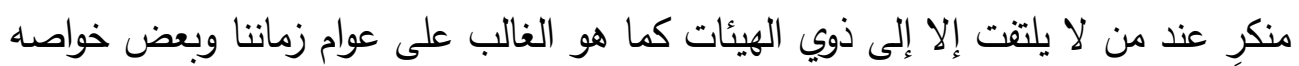

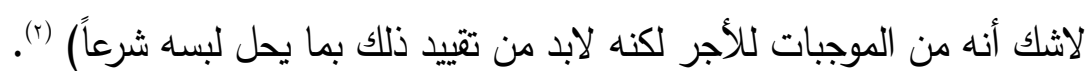
وجمال المظهر لا يعني أبداً أن يكون اللباس غالي الثمن، والعطر نادر

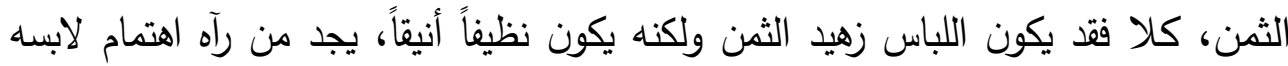

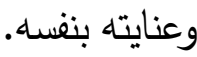

$$
\text { والأمر الأول: الثر حسن الثياب يجب التنبيه على عدة أمور : }
$$

وأقصد بهذا القيد أن الثياب في الإسلام له أوصاف معينة متى تحققت كان

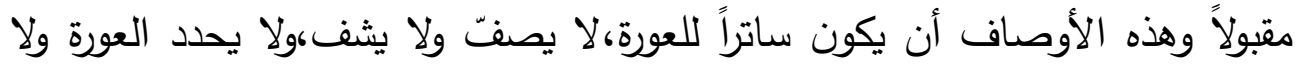

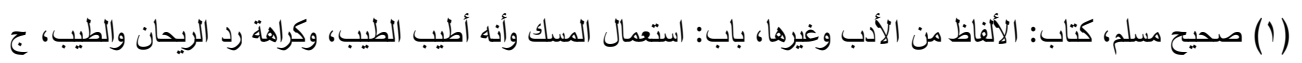
r r rOr

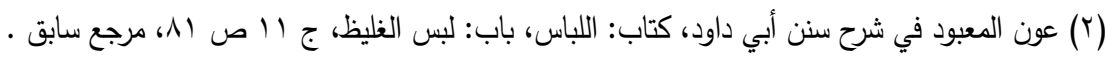


لغة الجسد بين الإسلام والدراسات التنموية البشرية وأثرها على المدعو

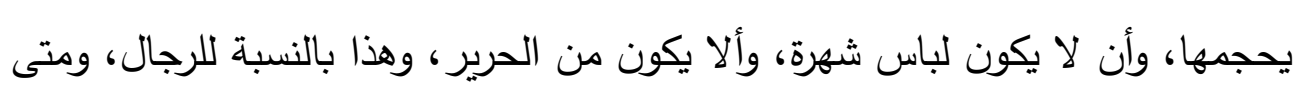

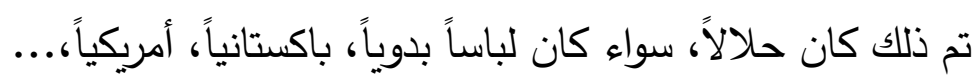

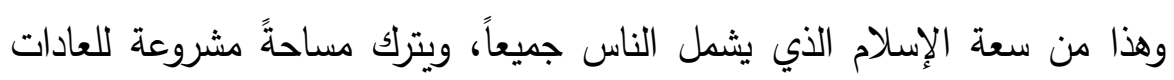

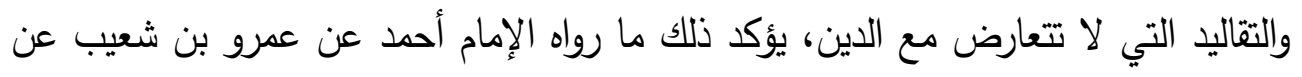

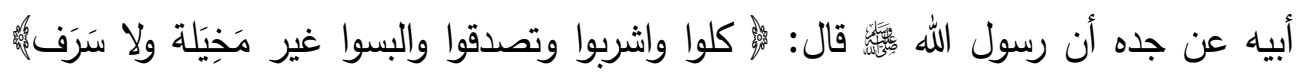
وقال يزيد بن مرة: في غير إسراف ولا مخيلة هن (1)

لذا نجد النبي

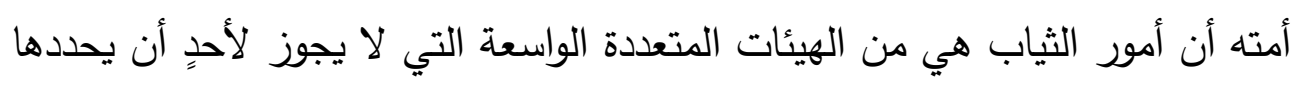

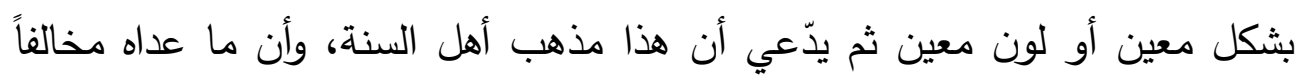

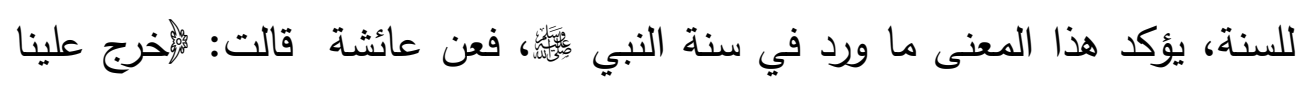

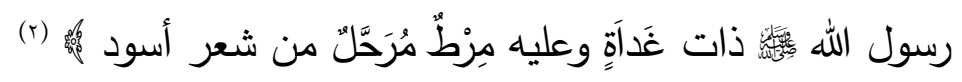

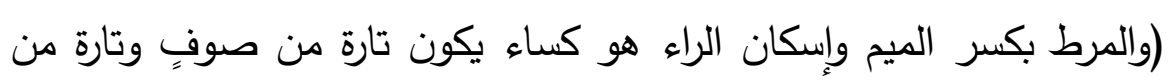

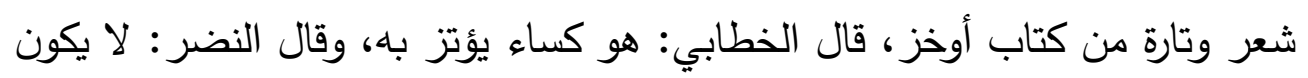

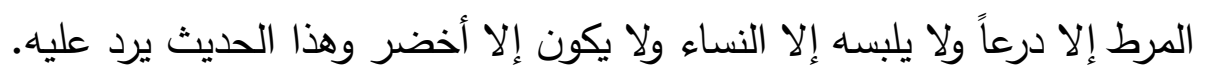

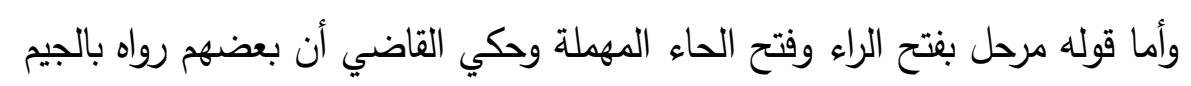

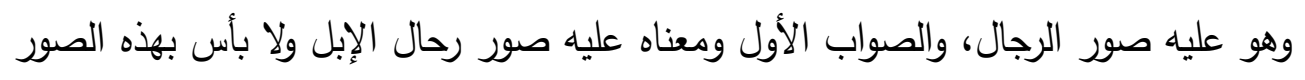
وإنما يحرم تصوير الحيوان.

وقال الخطابي:المرحل الذي فيه خطوط، وأما قوله من شعر أسود فقيده بالأسود لأن

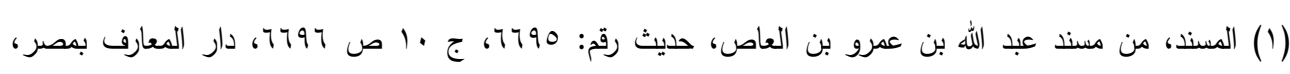

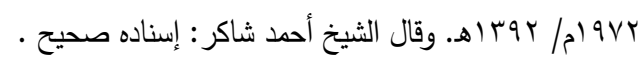

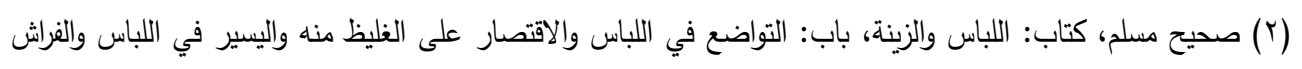

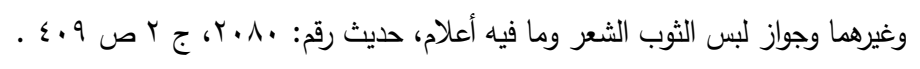


لغة الجسد بين الإسلام والدراسات التنموية البشرية وأثرها على المدعو

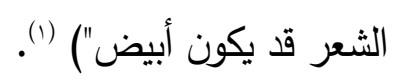

فالنبي

$$
\text { والأشكال. }
$$

حدثنا قتادة قال: بل قلنا لأنس بن مالك أي اللباس كان أحب إلى رسول الله

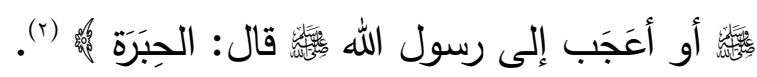

(والحِبَرَة هي بكسر الحاء وفتح الباء ثياب من كتان أو قطن محبرة أي مزينة. والتحبير التزين والتحسين، والحبرة مفرد الجمع حبر وحبرات كعنبة وعنبات، وفيه جواز لبس المخطط) (r) وعن أبي بردة قال: ولمّ دخلت عليّ عائشة فأخرجت إلينا إزاراً غليظاً مما

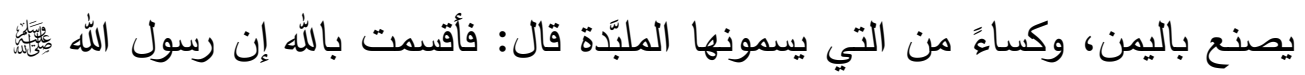
قبض في هذين الثوبين (s)

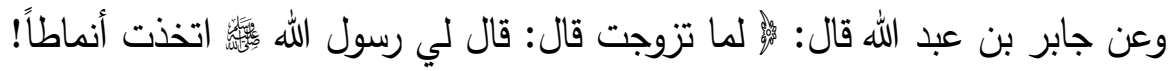
قلت وأنيّ لنا أنماطاً، قال: أما إنها ستكون، قال جابر وعند امرأتي نمطُ فأنا أقول نحيّه عني

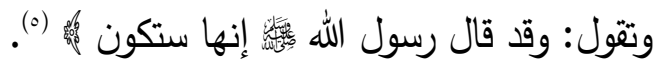

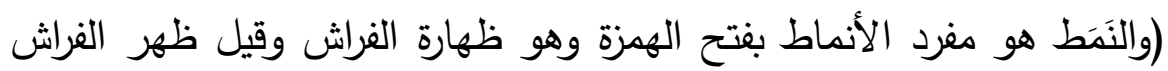
ويطلق أيضاً على بساط لطيف له خمل يحمل على الهودج، وقد يجعل ستراً وفيه

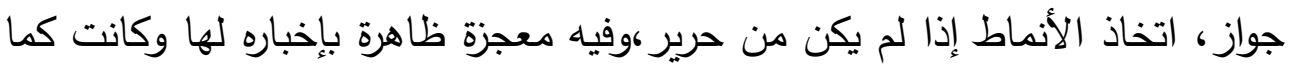

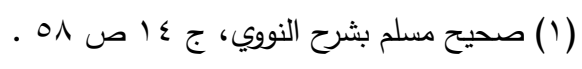

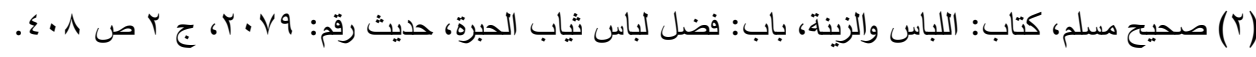

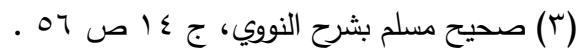

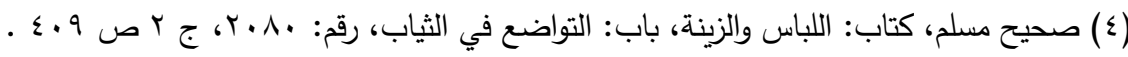

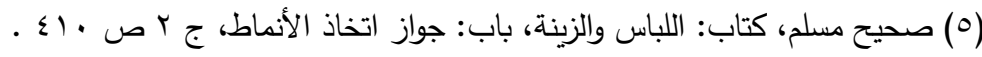


لغة الجسد بين الإسلام والدراسات التنموية البشرية و أثرها على المدعو

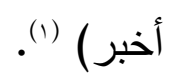

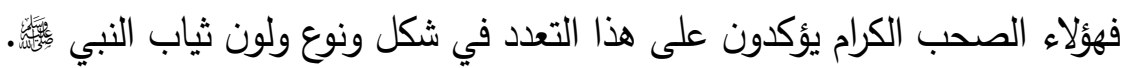
وعن مسروق قال: ولغ حدثي المغيرة بن شعبة انطلق رسول الله

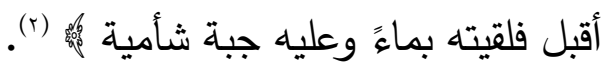

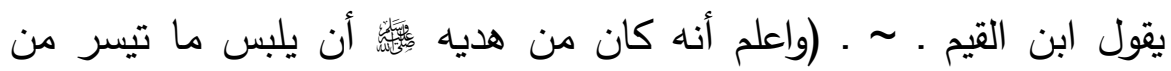
اللباس؛ الصوف تارة، والقطن أخرى، والكتان تارة، ولبس البرود اليمانية، والبُرْد من البه

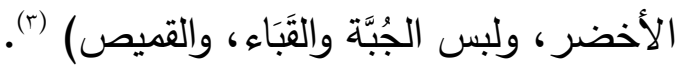

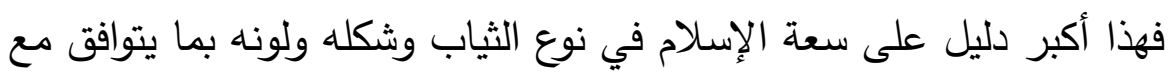

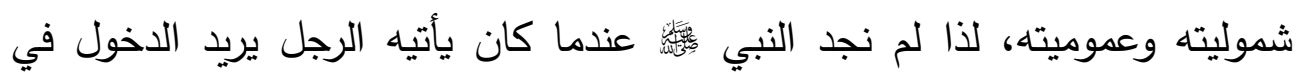
الإسلام يأمره بتغيير ثيابه إلى شكل معين، أو لون معين؛ بل يترك ذلك للكئه للعادات والتقاليد، طالما اتسم الثوب بالثروط السابقة.

وإن المرء ليعجب من بعض الدعاة ـ يدعَون التمسك بالسنة وأنهم من أنصارها

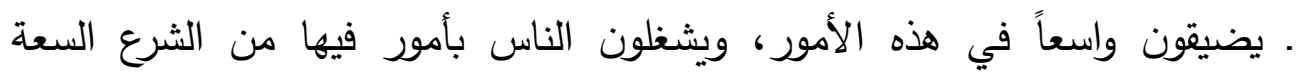

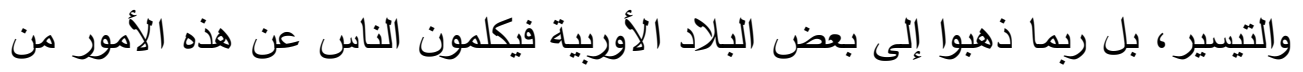

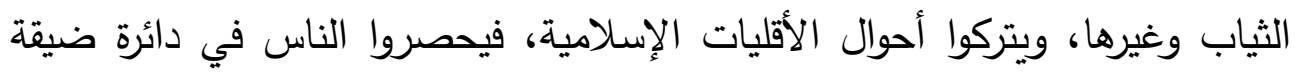

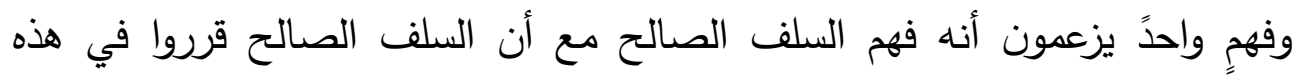
المسألة غير ما قرروا.

الأمر الثاني: طول الثوب وتقصيره:

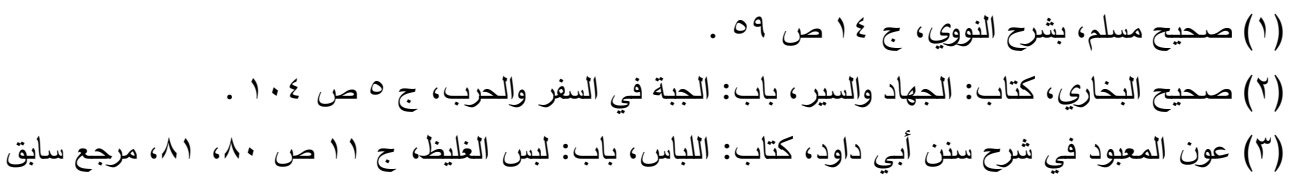


لغة الجسد بين الإسلام والدراسات التنموية البشرية و أثرها على المدعو

الضابط في طول الثوب وتقصيره يرجع إلى النية، فإن كان الثوب طويلاً

والنية فيه الخيلاء والكبر والعجب فهذا هو المرفوض لاقتران النية السيئة فيه.

وإن كان الثوب طويلاً أسفل الكعبين ولا توجد نية الكبر ولا الخيلاء ولا

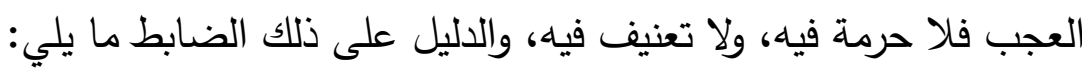

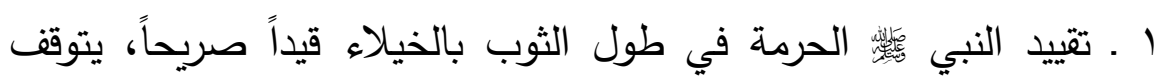

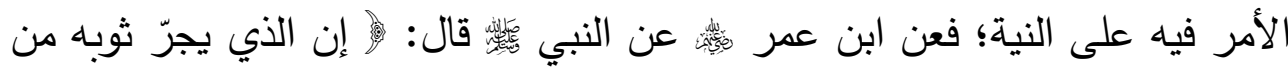

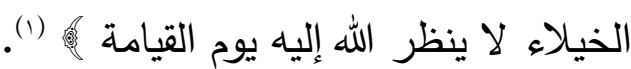

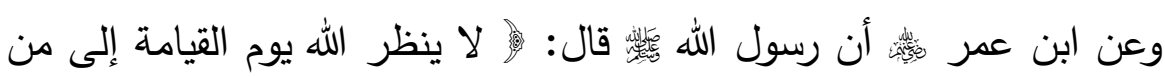

جر ثوبه خيلاء

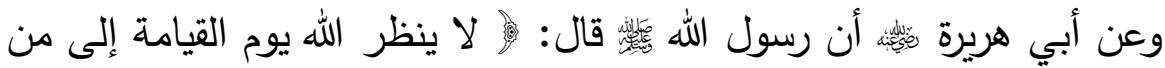

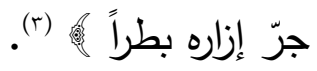

عن ابن عمر قال: سمعت رسول الله

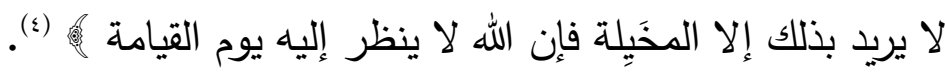

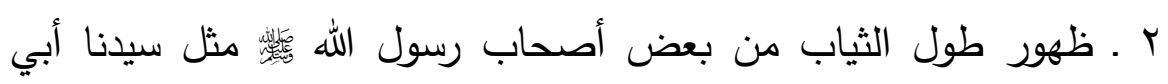

بكر ، وعبد الله بن مسعود، وعبد الله بن أنيس.

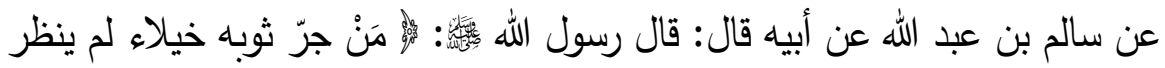

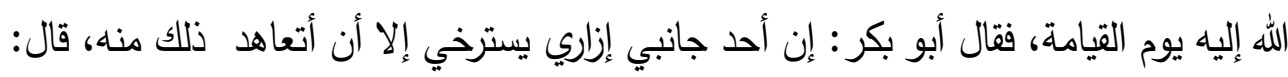

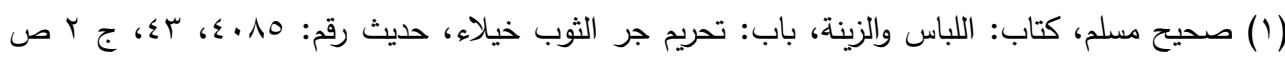

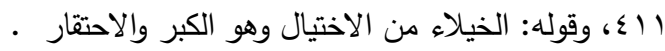

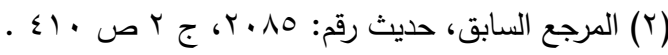

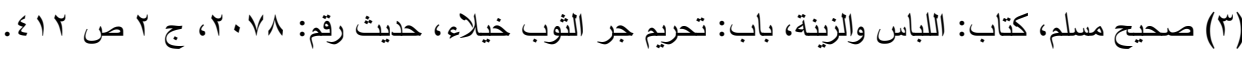

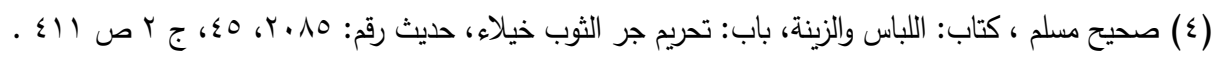


لغة الجسد بين الإسلام والدراسات التنموية البشرية و أثرها على المدعو

لست ممن يفعله خيلاء (1) (1)

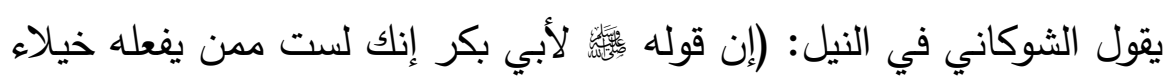

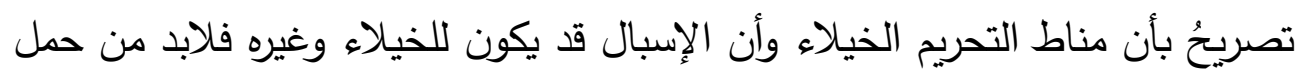

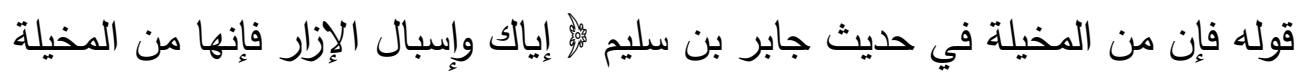

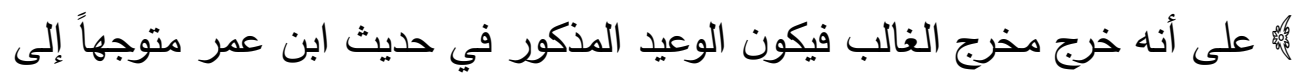

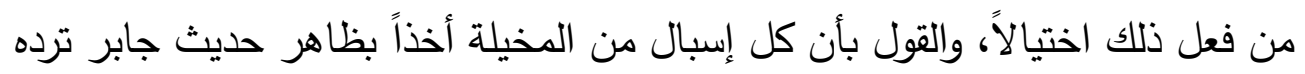
الضرورة، فإن كل أحدٍ يعلم أن من الناس من يسبل إزاره مع عدم خطور الخيلاء بباله الناله

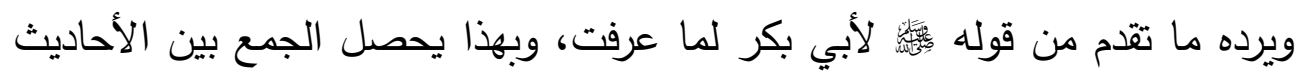

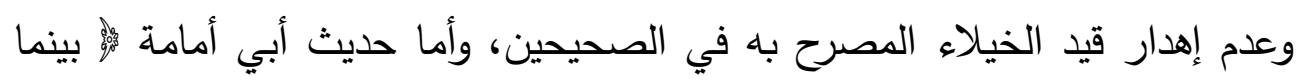
نحن مع رسول الله

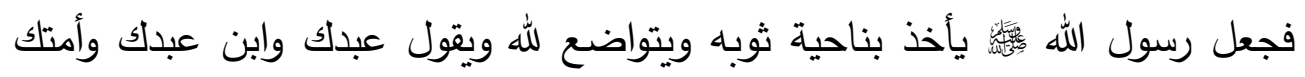

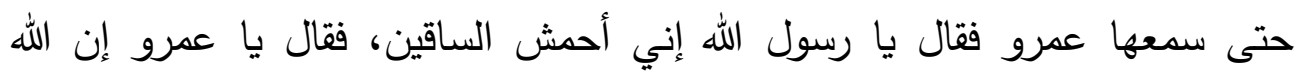

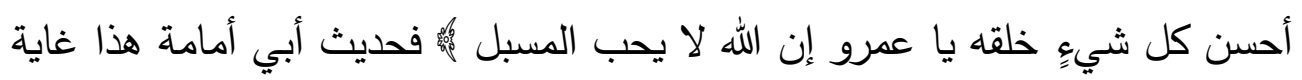

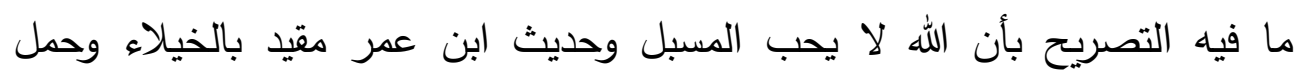

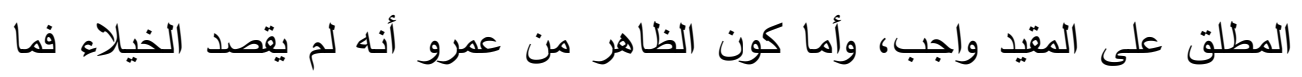
بمثل هذا الظاهر تعارض الأحاديث الصحيحة).

ويقول القاري: (المعنى أن استرخاءه من غير قصدٍ لا يغير لاسيما ممن لا يكون من

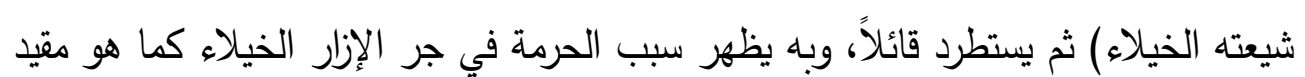

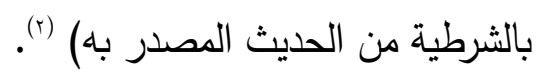

وطول ثياب سيدنا عبد الله بن أنيس يؤكدها الإمام أحمد في مسنده حدثا 
لغة الجسد بين الإسلام والدراسات التنموية البشرية وأثرها على المدعو

يزيد أخبرنا همام بن يحيى عن القاسم بن عبد الواحد المكي عن عبد الله بن محمد بن

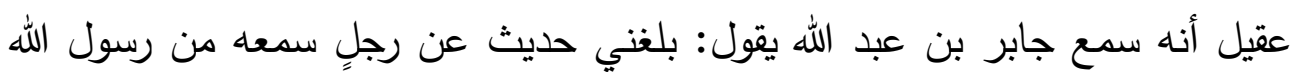


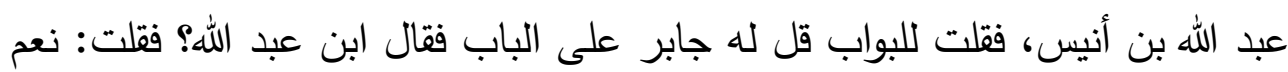
فخرج يطأ ثوبه فاعتتني واعتنقته فقلت حديث بلغني عنك أنك سمعته من رسول الله

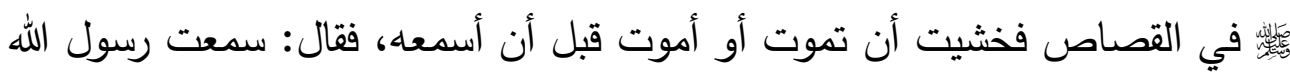

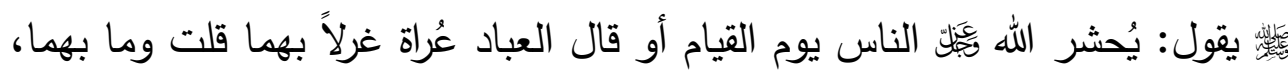

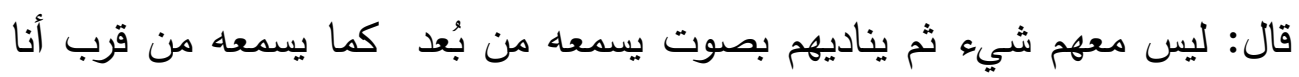

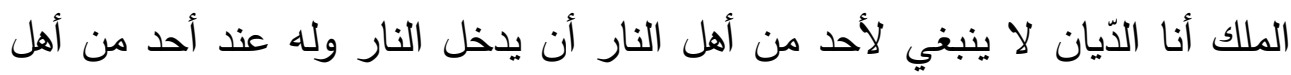

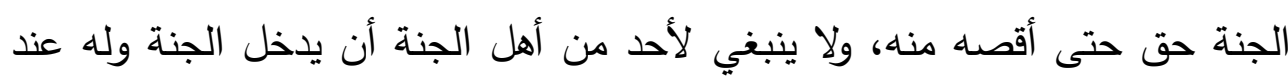

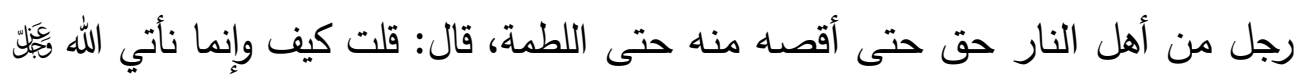

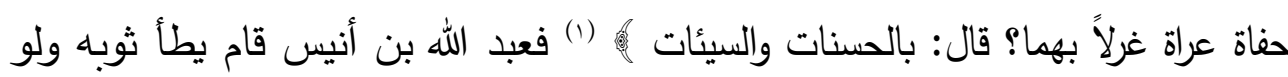
كان قصيراً ما وطأه.

ـ ـ القاعد الأصولية أن العام يُخَصصَ إذا وجَدَ مخصصاً، وبناء على فهم ألماه

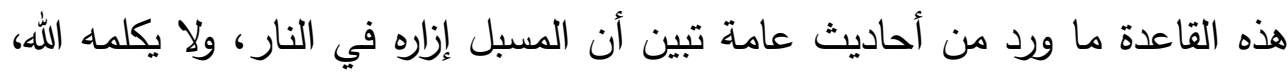
وغير ذلك، يحمل على الخاص الذي تقيد إطالة الثوب بنية الكبر والعجب. يقول الإمام النووي . . (وظواهر الأحاديث في تقييدها بالجر خيلاء تذل

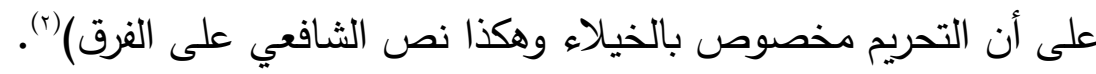

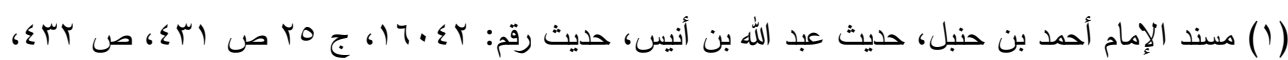

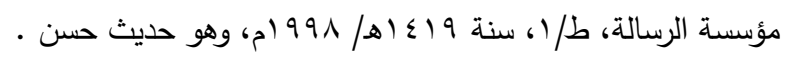

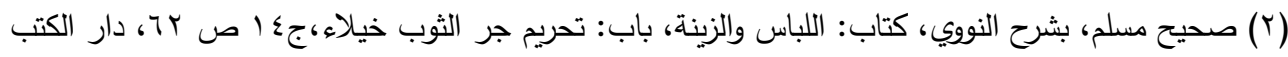


لغة الجسد بين الإسلام والدراسات التنموية البشرية وأثرها على المدعو

ه ـ بوبّ الإمام مسلم لهذا المعنى فقال: بل باب تحريم جر الثوب خيلاء وبيان

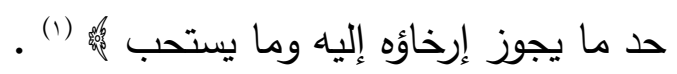

\section{الأمر الثالث: تخصيص ثياب لمهنة معينة:}

يجوز لولي الأمر تخصيص ثوبٍ معين لفئةٍ معينةٍ للتعريف بها، ولتحديد مسئوليتها، مثال ذلك تحديد زي خاص للأطباء والممرضين والمهندسين، وغيرهم. ومما يجوز تخصيصه زيٌّ خاص بأهل العلم الثرعي مثل الزى الأزهري،

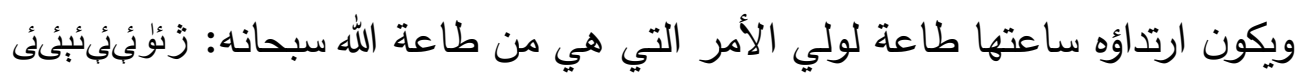
نُىىيز (r).

والدليل على ذلك أن النبي الحرب، ويلبس ثياباً جيداً خاصاً بالعيدين وغير ذلك. الني

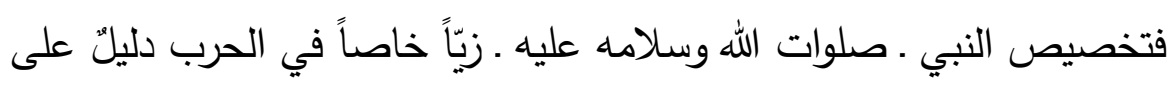

جواز ذلك التخصيص، وهو من تقييد المباح في الثرع لمصلحة شرعية.

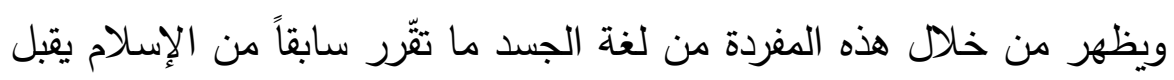

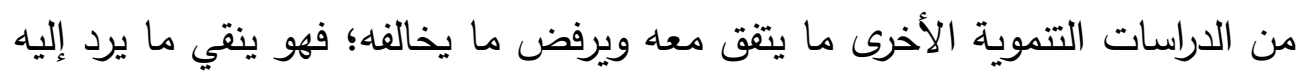

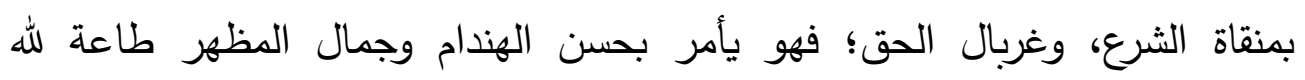

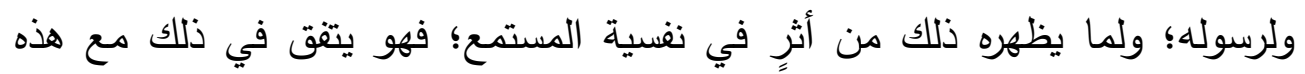

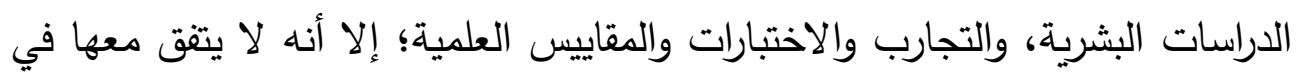
إباحتها الثياب الضيقة المحمة الثفافة التي لا تستر العورة ولا تحفظ عفة الإنسان.

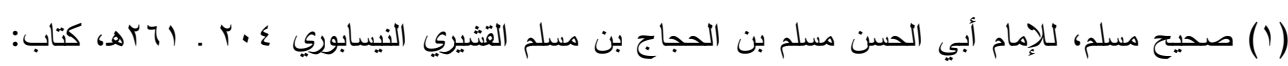

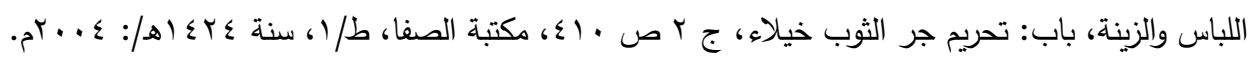

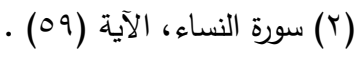


لغة الجسد بين الإسلام والدراسات التنموية البشرية وأثرها على المدعو

فالإسلام لا يقبل الكلام على علته ولا يرفضه من أصله بل يقف موقف الناقد

المتفحص البصير ؛ وهذا ديدنه وهذا منهجه؛ وسيعرف العلم الحديث مدى صدق ذلك

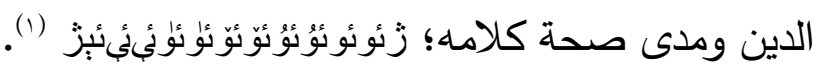

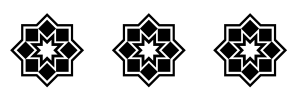

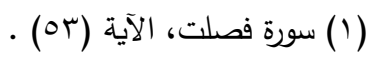

$-r \Delta 1-$ 
لغة الجسد بين الإسلام والدراسات التنموية البشرية وأثرها على المدعو

\section{المبحث الثاني \\ نظرات العين}

من المعالم الحقيقية في لغة الجسد نظرة العين؛ فنظرة العين قد تكون بناءةً

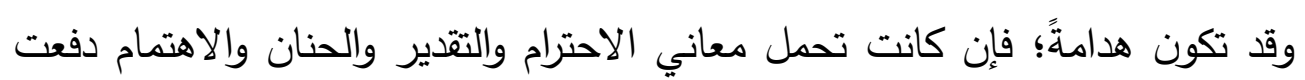

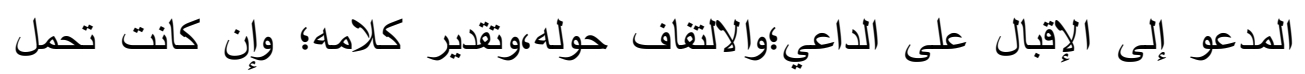

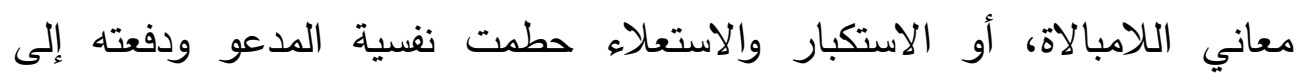

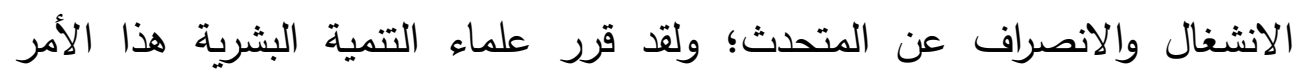

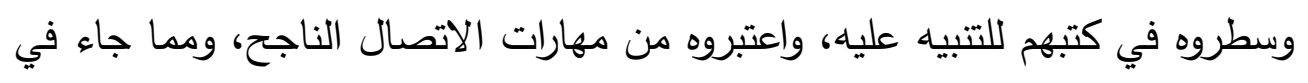

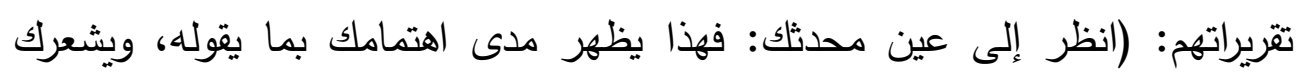

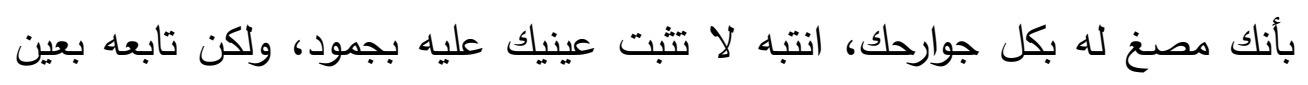

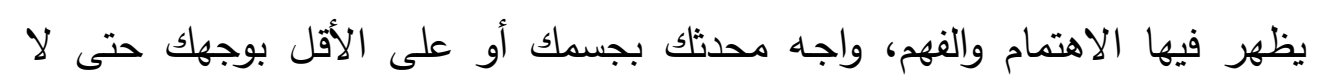
يشعر بأنك غير مهتم به أو تهمله) (1)

وعلى الداعية إلى الله أن يعلم أن الكلمات مجموعة أحرف مجردة لا تستطيع

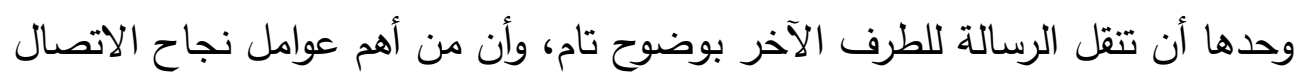

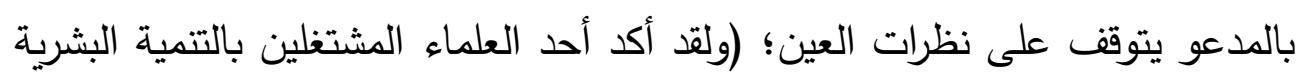

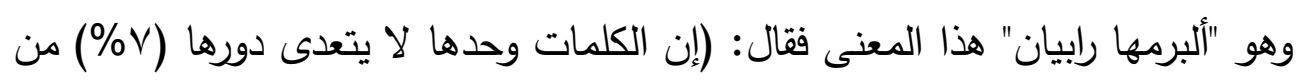

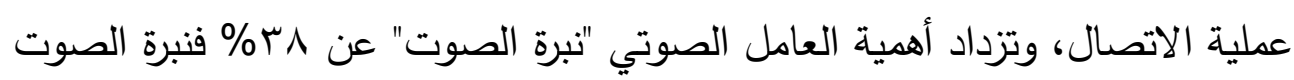

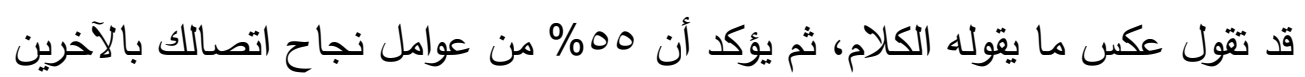

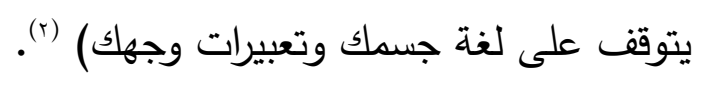

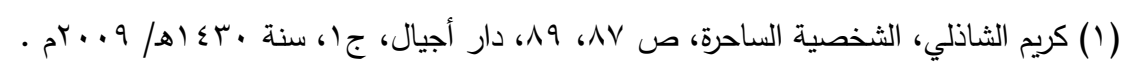

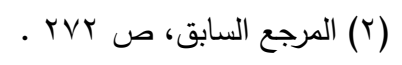


لغة الجسد بين الإسلام والدراسات التنموية البشرية و أثرها على المدعو

فالداعية إلى الله عليه أن يعلم أن العيون ناقلات للمعاني والرسائل والمشاعر،

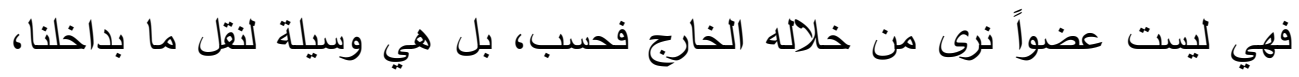
واستثفاف ما بداخل الآخرين.

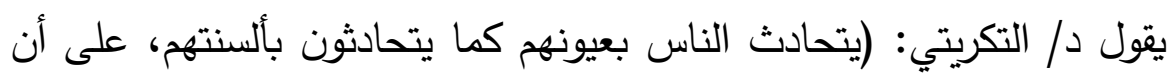

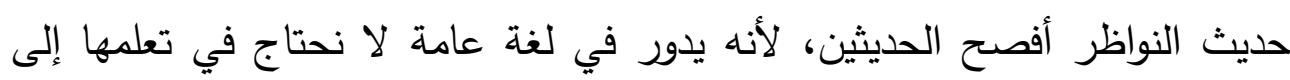

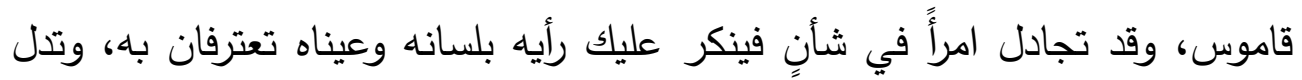

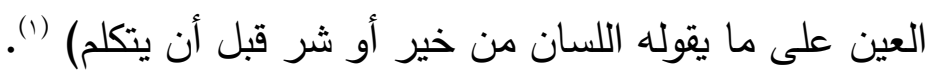
ولقد ذكر علماء النفس والاجتماع والتتمية البشرية بعض الأمور التي إن

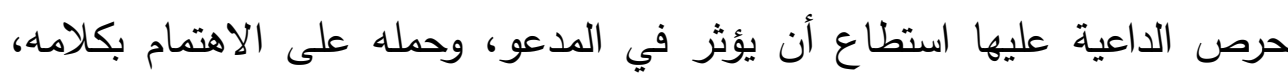
والانتباه لمواعظه، فقالوا:

(إذا أردت إيصال مرادك بعينك، فاحرص على الأمور التالية (r):

(1 ـ أن تكون عيناك مرتاحتين أثناء الكلام، مما يشعر الآخرين بالاطمئنان

إليك والثقة في سلامة موقفك وصحة أفكارك.

r ـ لا تتظر بعيداً عن المتحدث، أو تثبت نظرك في السماء أو الأرض أثناء

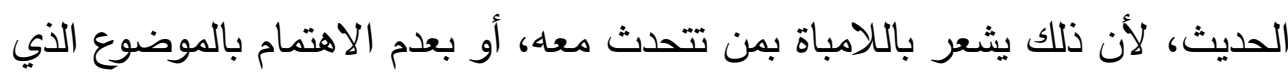

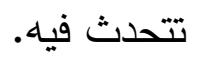

r ـ لا تطيل التحديق بشكل محرج فيمن تتحدث معه. ؟ ـ احذر من كثرة الرمش بعينيك أثناء الحديث، لأن هذا يشعر بالقلق

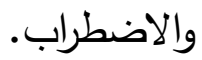


لغة الجسد بين الإسلام والدراسات التنموية البشرية وأثرها على المدعو

ه ـ ابتعد عن لبس النظارات القاتمة أثناء الحديث مع غيرك، لأن هذا يعيق

بناء الثقة بينك وبينه.

7 ـ ـ احذر من النظرات الساخرة الباهتة إلى من يتحدث إليك أو تتحدث معه،

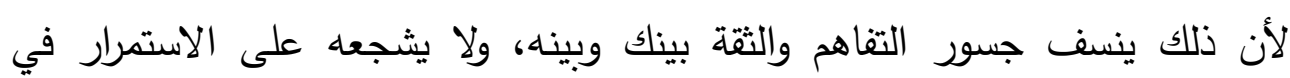
التواصل معك، (ورب نظرة أورثت حسرة).

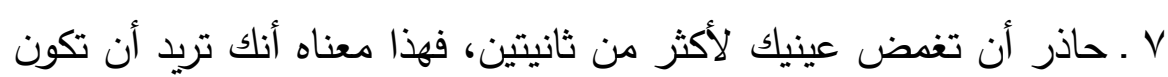
موجود في أي بقعة في العالم سوى هذا المكان.

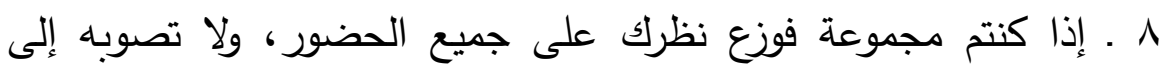

شخص واحد فقط.

9 ـ تأكد من أن نظراتك تحمل الدفء والود والمحبة والاهتمام والرعاية.

من خلال العينين تستطيع أن تكشف بعض ما يدور في ذهن محدثلك، فمثلاً

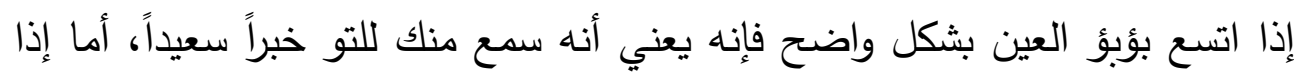

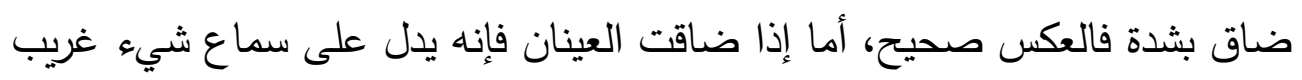

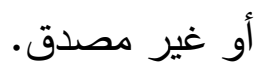

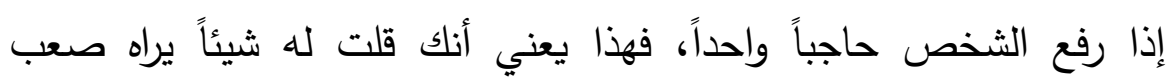
الحدوث أو التصديق، أما إذا رفع الحاجبين فإنها يعني سماعه لهآ لهفاجأة).

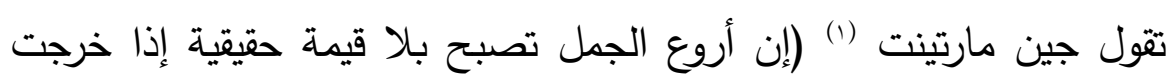
منك وأنت تتظر إلى الأرض أو إلى أقدام من تتحدث إلينه).

( (1) جين مارتين مؤلفة أمريكية شهيرة، تعيش في مدينة نيويورك ستي، تختلط بالناس، وتخرج من لقائها مع الثخصيات

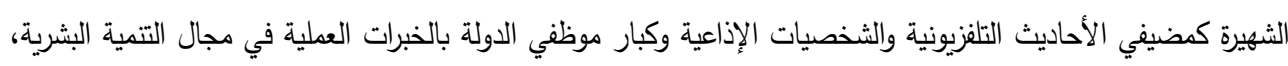

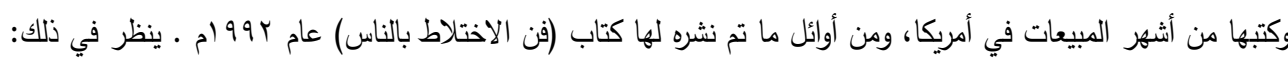

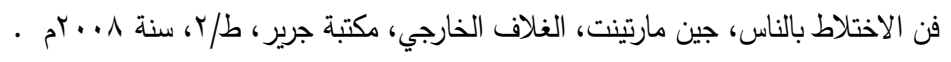


لغة الجسد بين الإسلام والدراسات التنموية البشرية وأثرها على المدعو

( إذا تعلدت كيف تستخدم عينيك جيداً فالأمر يساوي مليوناً من الدولارات،

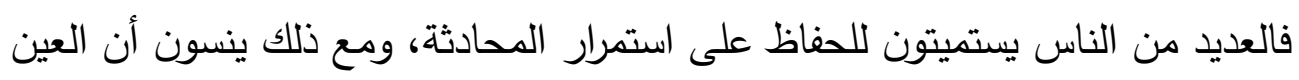

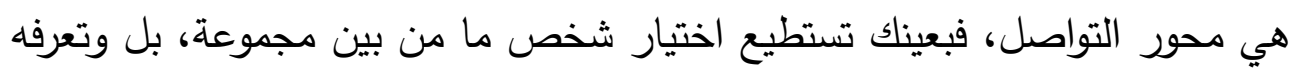

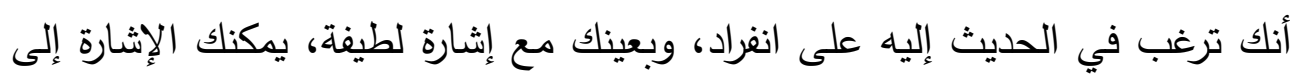
شيء ما في الغرفة حيث يمكنك استخدام تعبيرات العين بدلاً من الكلمات) (1). هذه المبادئ الجميلة، والمقررات الحكيمة، والمجربات المؤثرة، التي دعا إليها علماء التتمية البشرية يتفق معها الإسلام ويدعو إليها ويبينها تبياناً حكيماً؛ فيقرر أولاًا

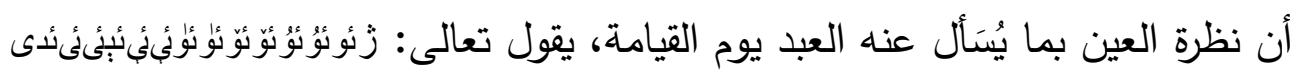

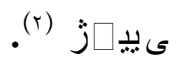

فالله يبين لنا أن الإنسان سيسأل عن سمعه وبصره وفؤاده، وسيحاسبه الله على ما يفعل من أفعال، ولاشك أن نظرات الاحتقار والازدراء والتكبر والاستعلاء لناء

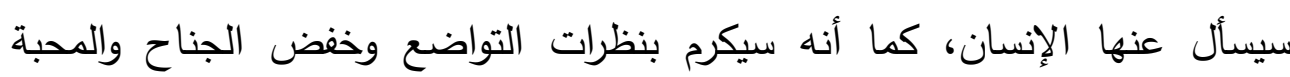

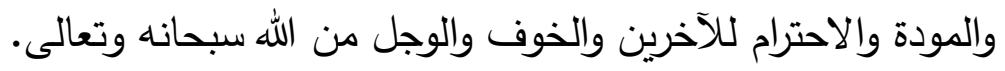

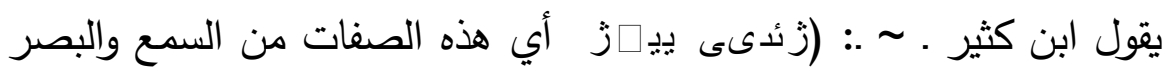

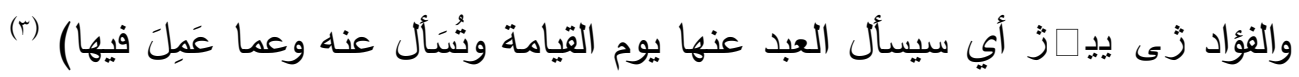
ومما لاشك فيه أن الداعية إن جدّد نيته أن تكون نظراته رسولاً من رسل التبليخ، وآئية

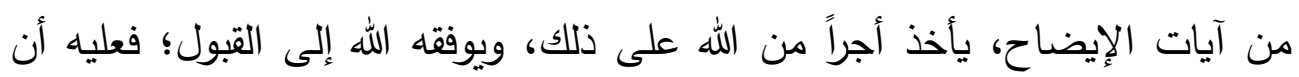

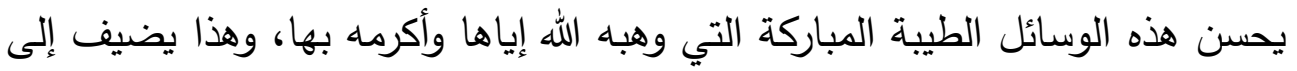
قوة تأثير العين في المستمع جانباً، آخر وهو طاعة الله سبحانه وتعالى. 
لغة الجسد بين الإسلام والدراسات التنموية البثرية وأثرها على المدعو

ويقرر الإسلام كذلك أن نظرة العين تستطق ما بداخل الددعو؛ فيتمكن

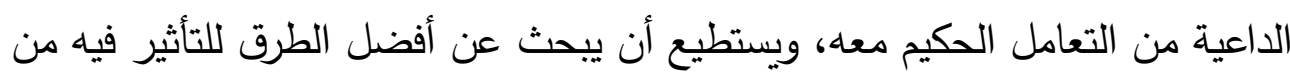
ذلك ما حكاه لنا القرآن الكريم من قصة المعوقين والمثبطين لإخوانهم عن الجهاد؛ قال

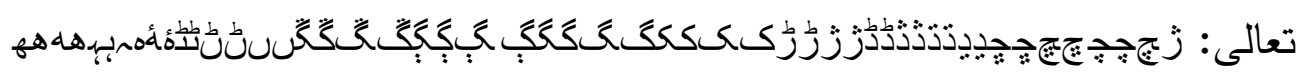

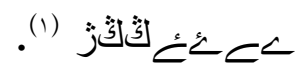

فالقرآن الكريم في هذه الآيات يبين صنفاً من الناس في حالات السلم، أقوياء،

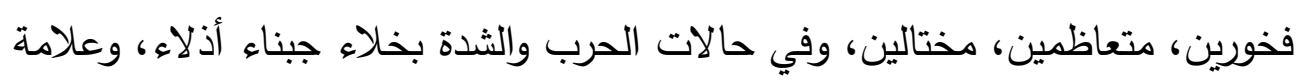

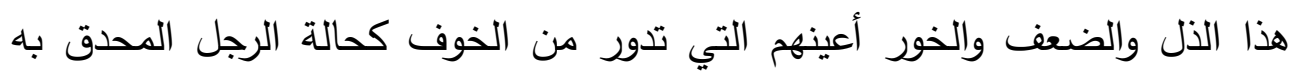

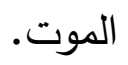

يقول الثيخ/ سيد قطب . .: (هي صورة شاخصة، واضحة الملامح، متحركة

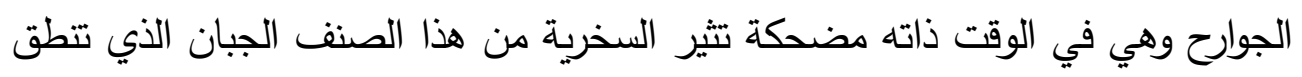

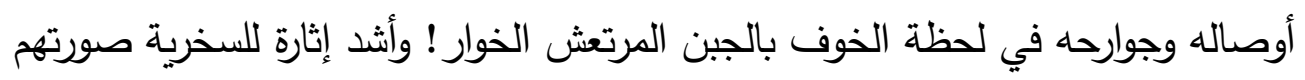

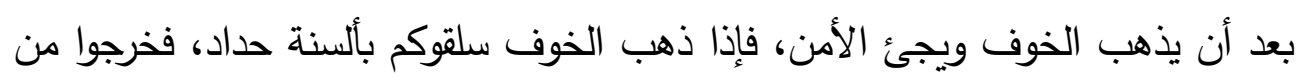

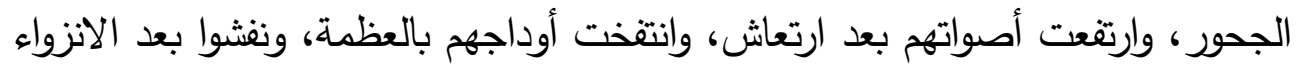

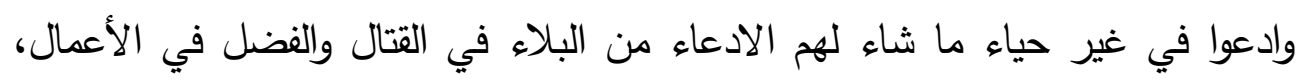
والثجاعة والاستبسال) (r)

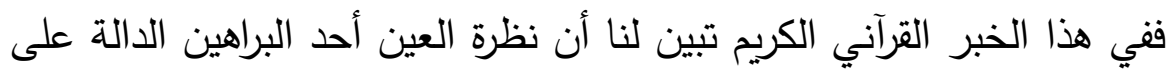

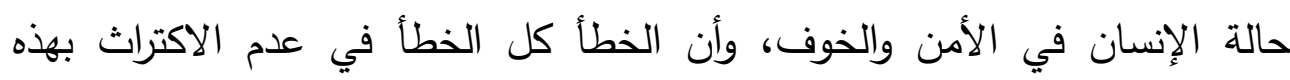

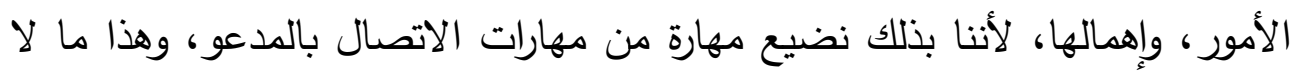

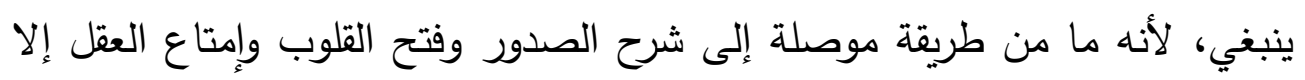

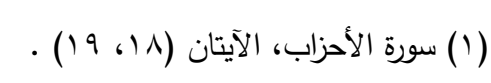

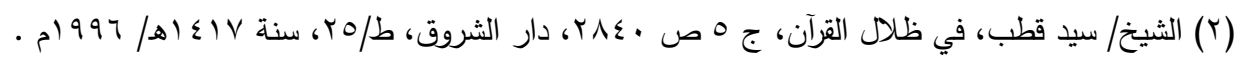


لغة الجسد بين الإسلام والدراسات التنموية البشرية و أثرها على المدعو

علينا الأخذ بها وتتميتها وتجليتها للآخرين.

والسنة النبوية راعت هذا الأمر ..

فصاحبها

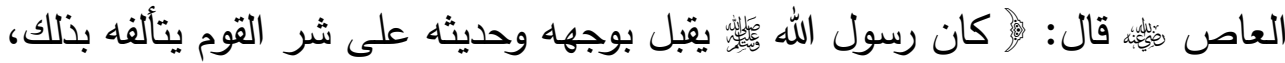
وكان يقبل بوجهاه وحديثه عليّ حتى ظننت أنيّ خير القوم بـ (1)

فالنبي ينتبهوا إلى نظراتهم الموجهة نحو المدعوين، وأن يحوطوا مستمعيهم بالعناية والاهتمام ودليل ذلك النظرة التي تعتبر بريد القلب.

وعلى المتحدث والداعية أن يراعي بنظره من يحدثه من المستمعين، ولا ينظر إليه شذراً

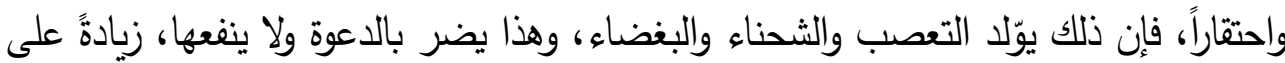
ذللك أن احتقار المدعو والنظر إليه شذراً واحتقاراً وعدم الاهتمام به يدل على الجهل بسنة رسول الله

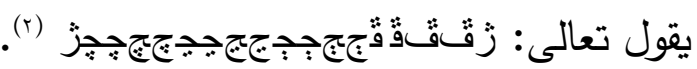

وإذا كانت العين بريد القلب؛ فعلى الداعية إذا تعرض لبعض المواقف الموهنة لقوته؛ أن يُقَلب نظره إلى المحبين له المقتنعين بكلامه؛ حتى يتحول إلى الإطار

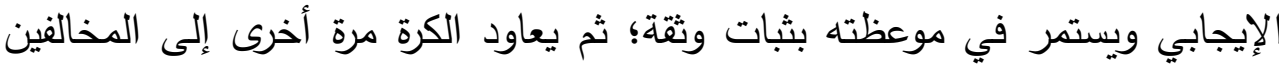

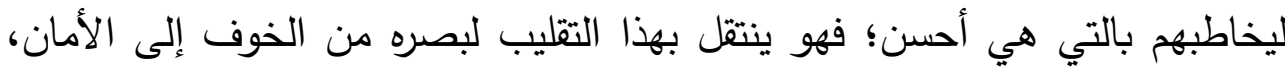
ومن فقد الثقة إلى قوة النفس ورباطة الجأش وهذا ما أكده أهل الخبرة والحكمة والتجربة لئي في الإنلام حيث قالوا: (إن هنالك مواقف يتعرض لها الخطيب قد توهن قوته، وتجعله 
لغة الجسد بين الإسلام والدراسات التنموية البشرية و أثرها على المدعو

يغيّر مجرى خطبته، أو يوجزها أو يحذف بعض عناصرها ولكن الخطيب الجرئ لا

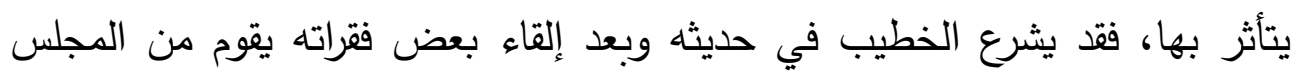

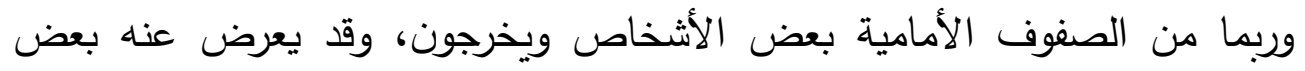

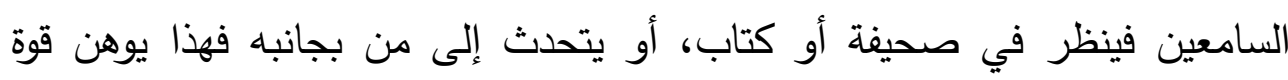

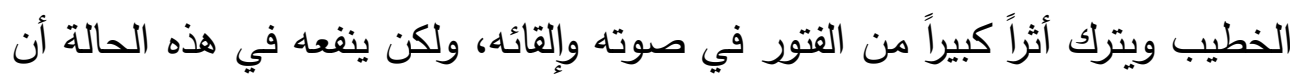

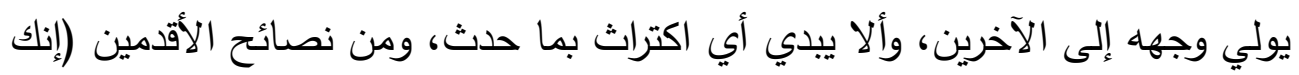

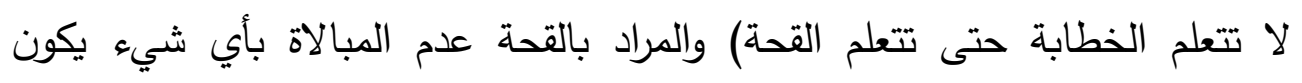

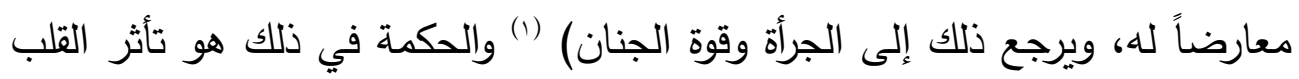

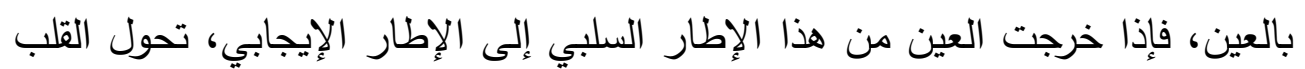

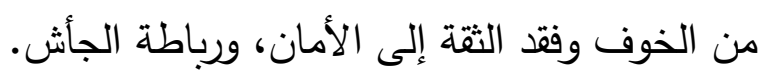


لغة الجسد بين الإسلام والدراسات التنموية البشرية و أثرها على المدعو

\section{المبحث الثالث}

\section{حركـة الـــرأس}

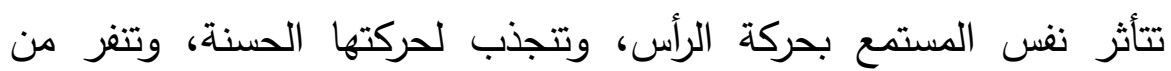
حركتها الخبيثة؛ فحركة الرأس عليها عامل كبير وقوي في التأثير في المستمعين؛ لأن

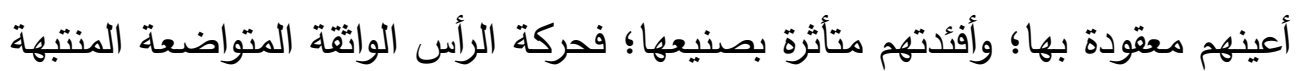

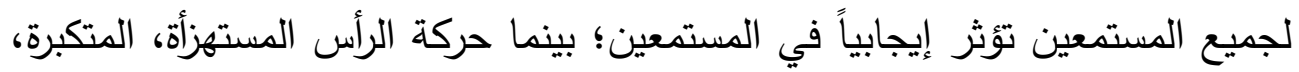

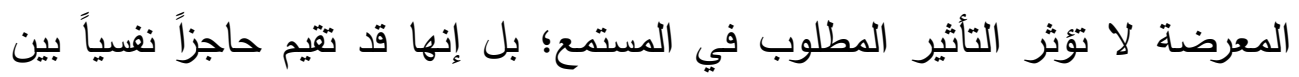

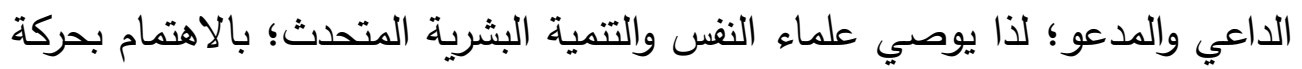

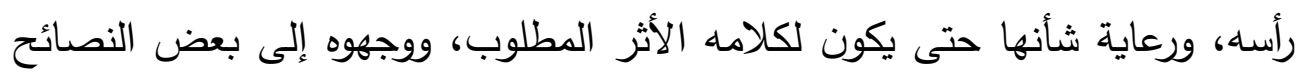
المفيدة في هذا الثأن: (تحدث ورأسك مرتفع إلى الأعلى؛لأن طأطأة الرأس أثناء

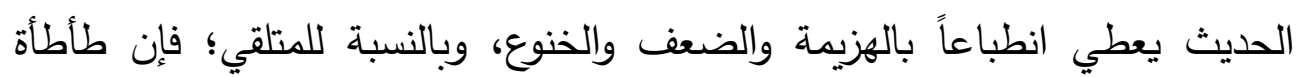
الرأس وقضب الجبين دلالة على تعكر مزاج المستمع أو سماعه لخبر سيئ، أما قضب الجبين ورفع الرأس فإنه يدل على الدهشة والحاجة إلى التوضيح) (1). وهذه المعاني المستقاة من حركة الرأس يتقق عليها العقلاء من الناس؛

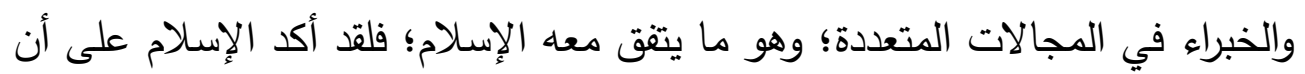

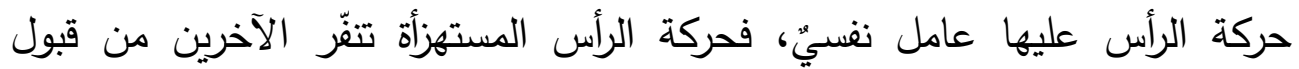

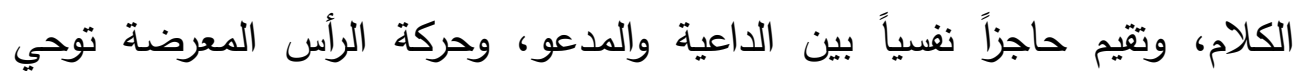

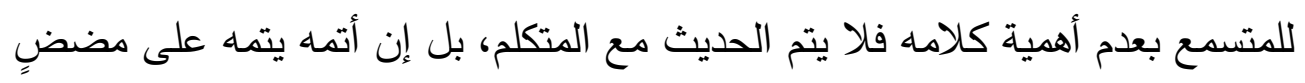
وتحفرٍ وكرٍ، وحركة الرأس المتكبر تلقي الكره والبغض في نفس المستمع فلا يرتاح

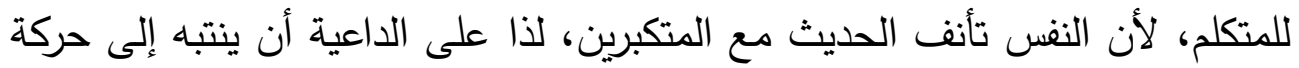


لغة الجسد بين الإسلام والدراسات التنموية البشرية وأثرها على المدعو

رأسه مع المدعوين، حتى لا يفسد في موضع يرجو فيه الإصلاح؛ لذا نجد القرآن

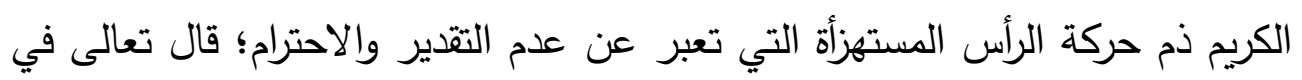

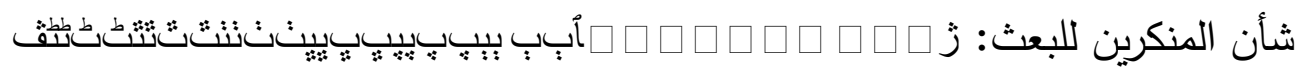

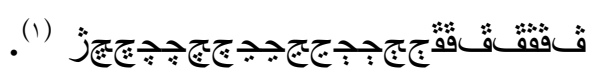

في هذه الآيات المباركات يبين الله سبحانه وتعالى موقفاً من مواقف المشركين المنكرين للبعث والنشور، فهم ينكرون أن يحيي الله العظام وهي رميم، فتحداهم الله

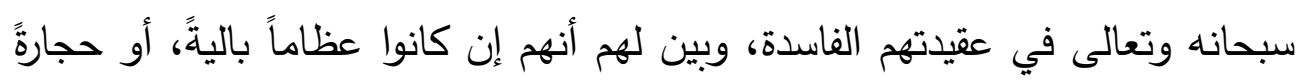

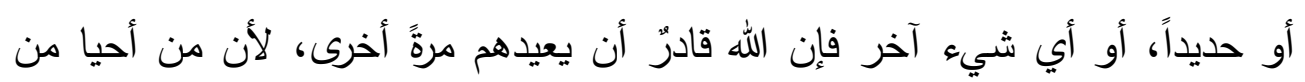

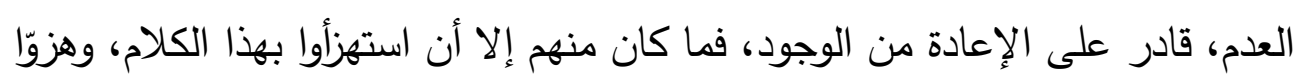

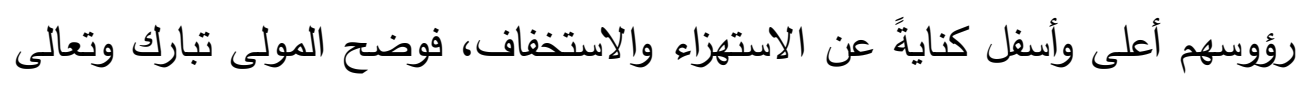
لهم أنها سيقفون بين يديه ويحاسبهم على هذه الأفعال الثنيعة.

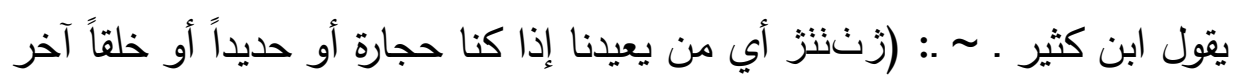

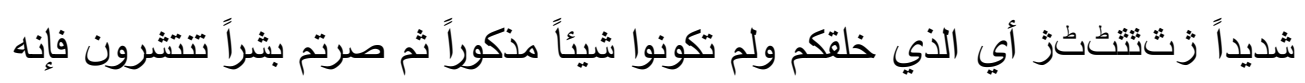

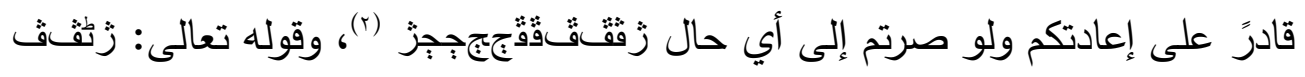

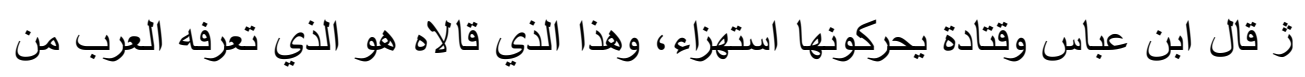
لغاتها، لأن الإنغاض هو التحرك من أسفل إلى أعلى أو من أعلى إلى أسفل، ومنه

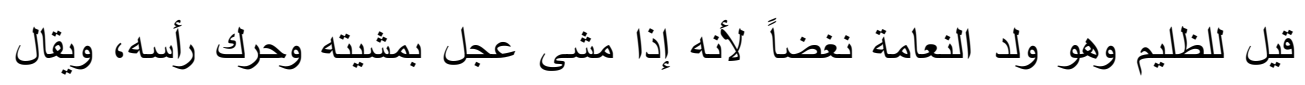
نغضت سنه إذا تحركت وارتفعت من منبتها) (r) • ونجد القرآن الكريم كذلك ذّم حركة الرأس المتكبرة التي لا تأبه بالآخرين ولا

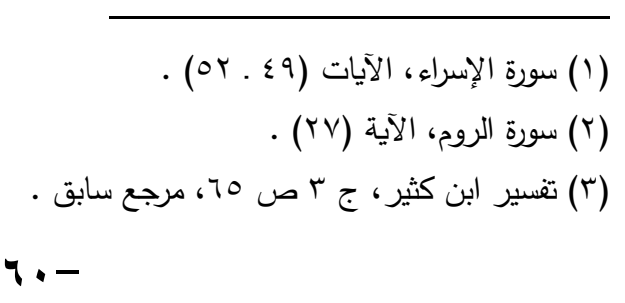


لغة الجسد بين الإسلام والدراسات التنموية البشرية وأثرها على المدعو

بما يقولونه وتستعيض عن الرجوع إلى الحق بحركات الكبر والغرور

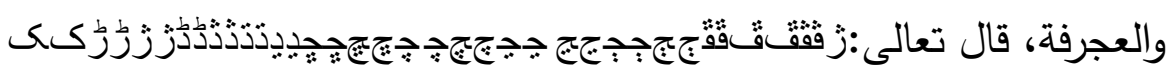

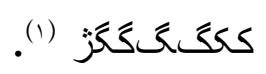

في هذه الآيات المباركات يبين الله صنفاً من الناس قتله الغرور والكبر فملاً

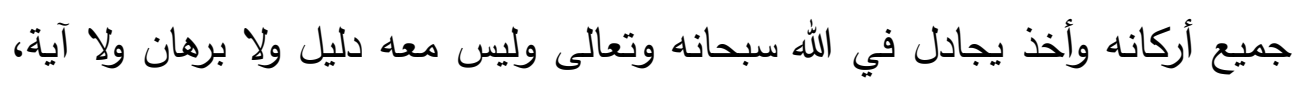

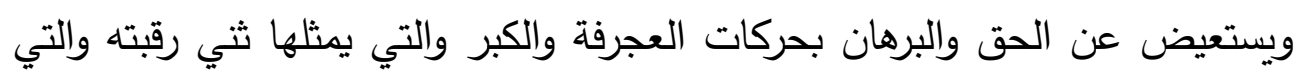

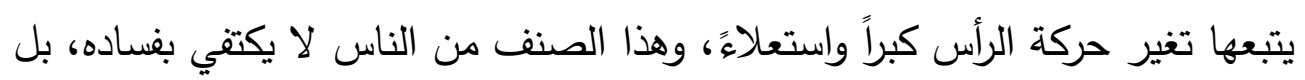

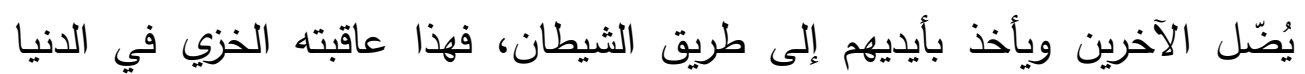
والآخرة جراء ما صنعت يداه.

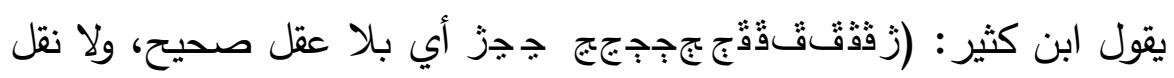

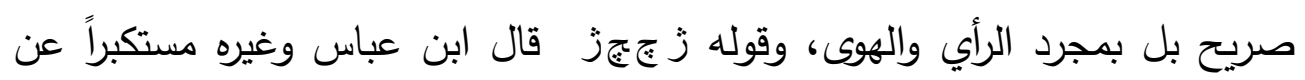

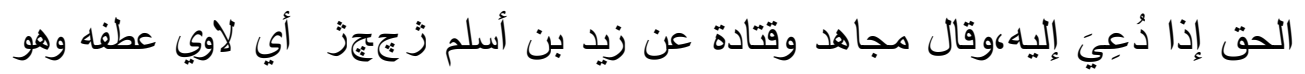

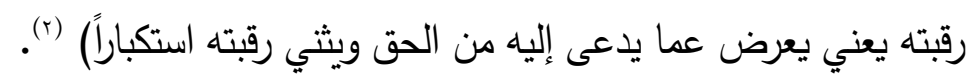

وفي بيان خطورة الرأس المعرضة عن الآخرين نجد لقمان الحكيم يوصي ابنه لئه بالابتعاد عنها لأثرها السيئ في نفية المخاطب؛ بين ذلك القرآن الكريم في قوله

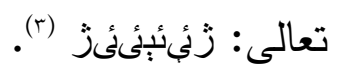

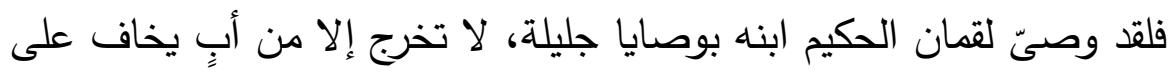

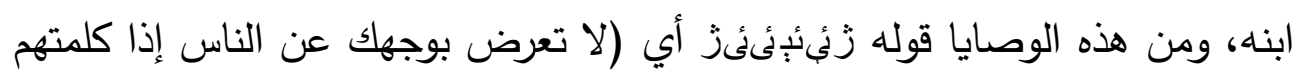

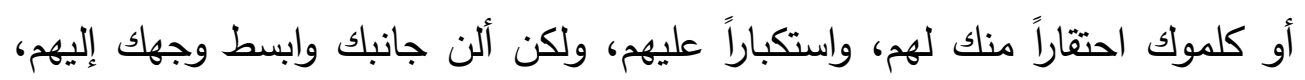

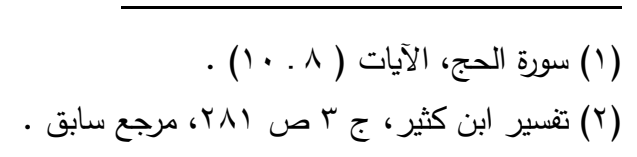

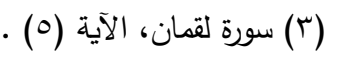


لغة الجسد بين الإسلام والدراسات التنموية البشرية وأثرها على المدعو

قال علي بن أبي طلحة عن ابن عباس في قوله زنئنبُ نُئئز يقول لا تتكبر فتحقر

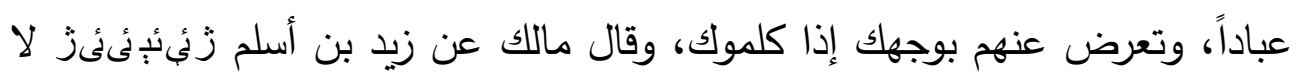

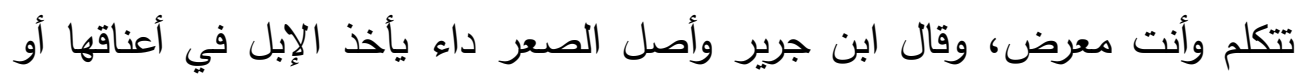
رؤوسها حتى تلفت أعناقها عن رؤوسها فشبه به الرجل المتكبر ) (1).

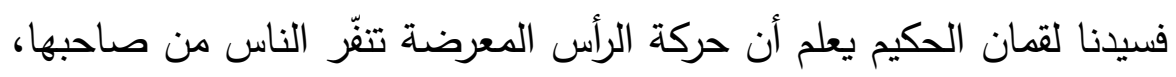
وتبعدهم عنه، لذا يوصي ابنه أن يبتعد عن هذه الحركة للجسد التي تنفّر الآخرين

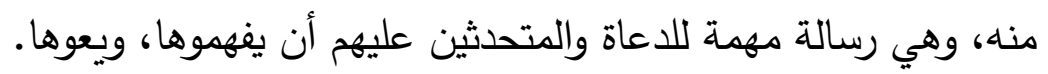
وفي بيان حركة الرأس الذليلة الخجلة يقول تعالى مبيناً حال المجرمين يوم

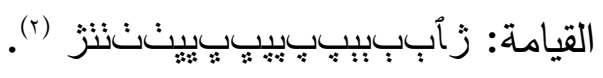

فهذه الآية الكريمة تبين حال المجرمين الذين عاينوا البعث والحساب والجزاء

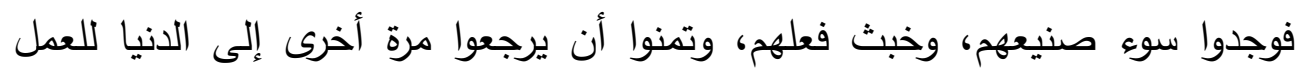

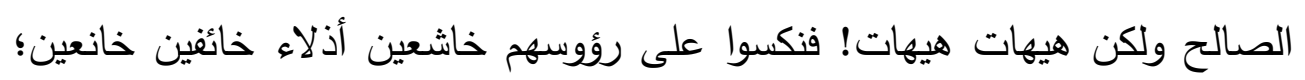

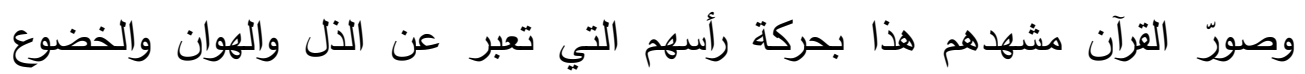

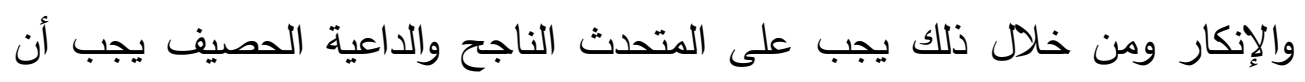
تكون حركة رأسه فيها الثقة بالله مع التواضع، وشموخ العلماء مع الخشية لله، لأن حركة الرأس الذليلة الخانعة تضعف ثقالثة الآخرين بها.

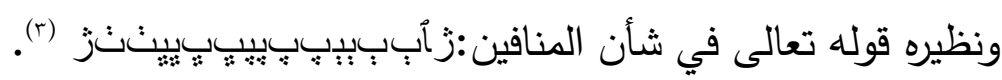

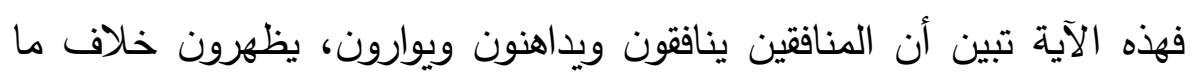
يبطنون،ويقولون ما لا يعلمون، وإذا دعوا إلى الحق والفضيلة وحركوا رؤوسهم يميناً 
لغة الجسد بين الإسلام والدراسات التنموية البشرية و أثرها على المدعو

وشمالاً، وأعلى وأسفل إعراضاً واستكبارا، فحركة رأسهم دآلّة على الإعراض والاستهزاء

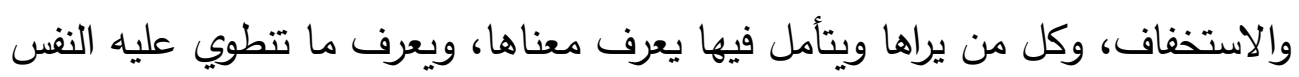

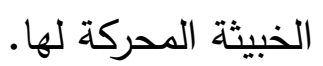

يقول ابن كثير . .: (يقول الله تعالى مخبراً عن المنافقين عليهم لعائن الله

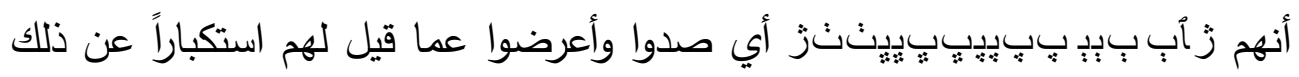

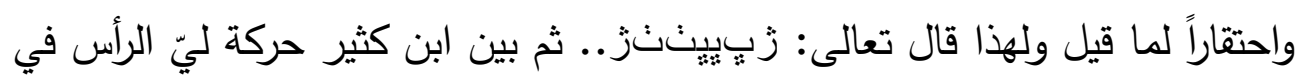
الآية الكريمة فقال: (حول سفيان وجهه على يمينه ونظر بعينه شذراً ثم قال هو هذا)، وقد ذكر غير واحد من السلف أن هذا السياق كله نزل في عبد الله ابن سلول) (1).

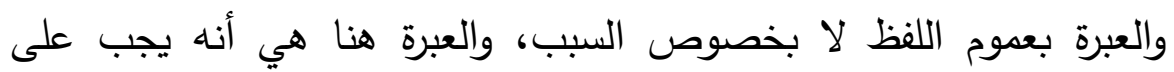
الدعاة والمتكلمين أن ينتبهوا إلى حركة رأسهم في الحديث، حتى تكون لدعوتهم القبول

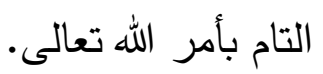

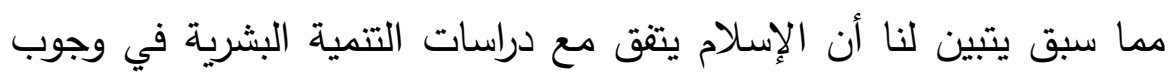
الاهتمام بحركة الرأس لأثرها في نفسية المستمع.

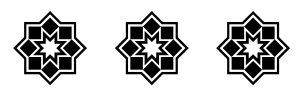


لغة الجسد بين الإسلام والدراسات التتموية البشرية وأثرها على المدعو

\section{المبحث الرابع}

\section{تعبيرات الوجـــهـ}

من أهم مغردات لغة الجسد (تعبيرات الوجه) لأن الوجه مرآة لما يختلج في

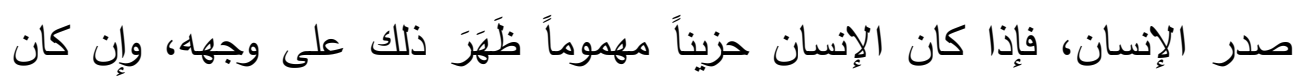

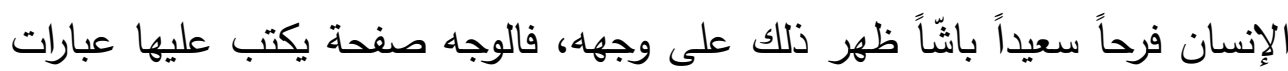
المشاعر القلبية.

ولقد أكد علماء النفس والتتمية البشرية وكبار الخطباء والمتحدثون على أن المتحدث الناجح والداعية الحاذق هو الذي يتفاعل مع الجمهور ومع الكلمات والأحداث، ويظهر ذلك التفاعل على قسمات وجهه، فإن كان الموقف فرحاً ظهرت

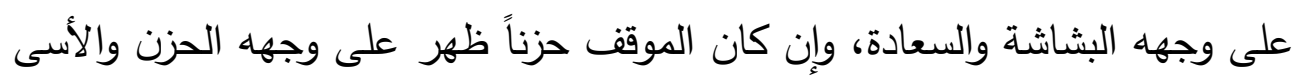

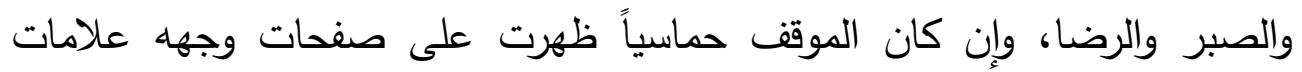

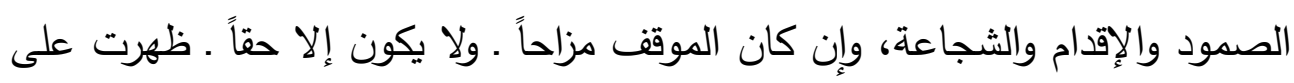

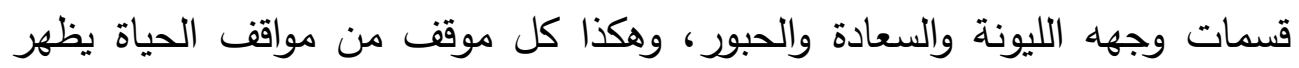
على صفحات وجه الداعية تعبيرات واضحة يقرأها كل من يراها. وأهمية هذا الأمر ترجع إلى أن عين المدعو متعلقة بالداعي تتأثز بهاه، والمشاعر بريد القبول، فالداعي الذي يعيش مع مدعويه ويشاطرهم الأفراح والأحزان

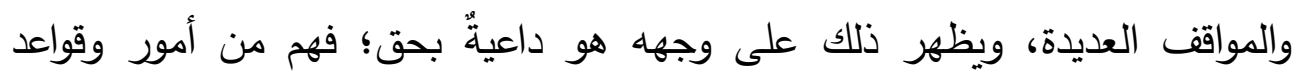
الدعوة ما يمكنه من القبول والإقناع.

وعلى الوجه الآخر، الداعية والمتحدث الذي يظهر على وجهه الوجوم في

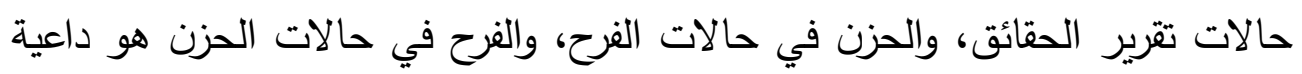
يستخف بالمدعوين، ويجرأهم عليه، وينفرهم منه، ويكون كالحي الأشبه بالميت. 
لغة الجسد بين الإسلام والدراسات التنموية البثرية وأثرها على المدعو

هذه الحقيقة يتقق عليها العقلاء والحكماء من كل حدب وصوب، لأن

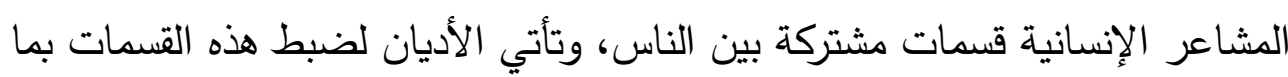

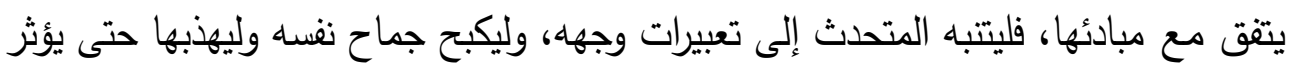

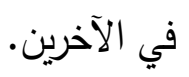

يقول د/ أحمد محمد الحوفي . أحد خبراء وعلماء فن الخطابة: (الوجه كله

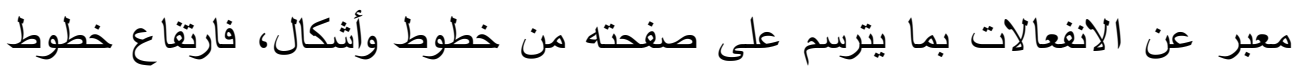

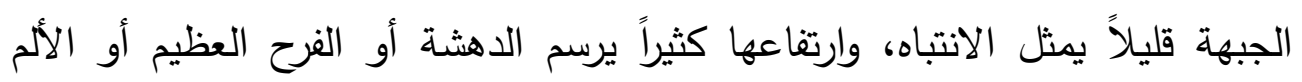
الأليم، وانخفاضها يدل على القلق والتفكير ) (1) والإسلام يقرّ هذه الحقيقة، فالقرآن الكريم في معرض ذكره عن أهل الإيمان،

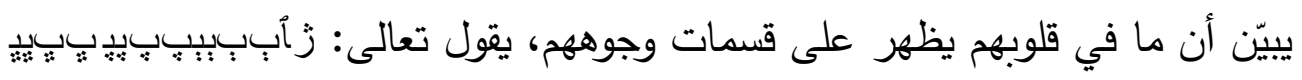

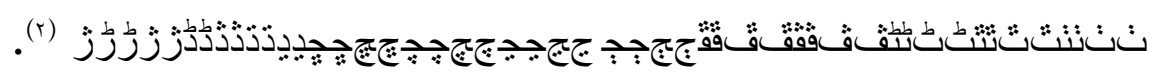
يقول سيد قطب . : ( زثطدثثث ثز سيماهم في وجوههم من الوضاءة

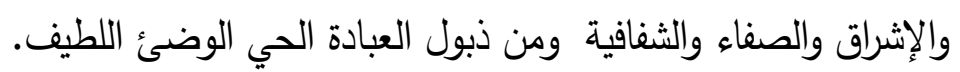

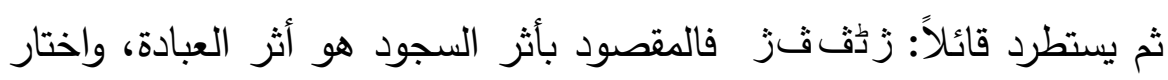

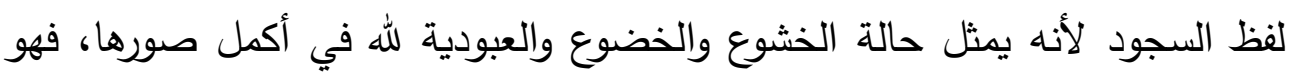
أثر هذا الخشوع أثره في ملامح الوجه حيث تتوارى الخيلاء والكبرياء والثراهة ويحل

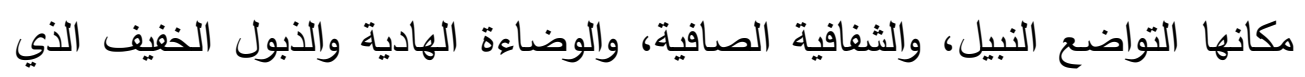

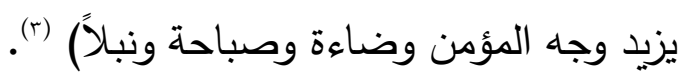
وفي وصفٍ آخر لما يظهر على الوجه من خبايا القلب نجد الله سبحانه ( (1) د/ أحمد محمد الحوفي، فن الخطابة، ص لآ، نهضة مصر، ط/ سنة هو ام ام .

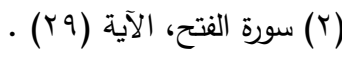

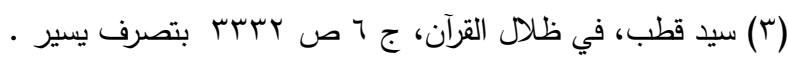


لغة الجسد بين الإسلام والدراسات التنموية البشرية وأثرها على المدعو

وتعالى يبين في حديثه عن أهل الطغيان والفساد أنهم عند سماعهم لآيات الله البينات

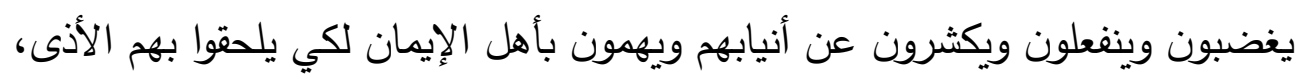

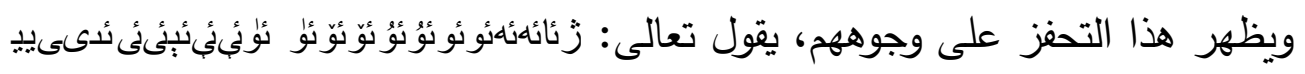

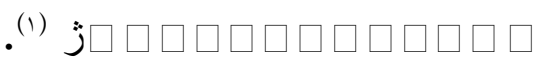

ويوضح الإمام الرازي هذه الآية فيقول: (فبين ـ تعالى ـ أنهم مع جهلهم إذا

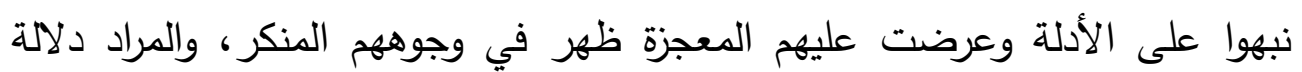
الغضب والغيظ، قال صاحب "الكثاف" المنكر الفظيع من التهجم والفجور والنشوز والإنكار كالمكرم بمعنى الإكرام... وللمفسرين في المنكر عبارات أحدها: قال الكلبي:

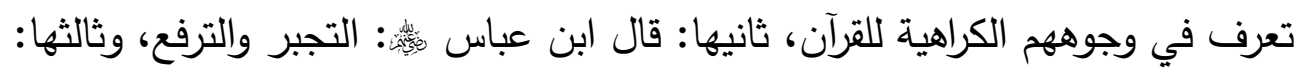

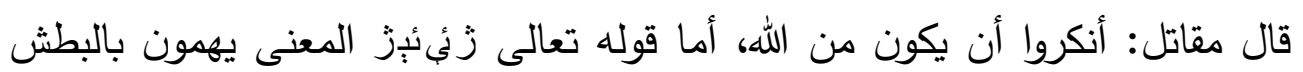
والوثوب تعظيماً لإنكار ما خوطبوا به فحكي تعالى عظيم تمردهم على الأنبياء والمؤمنين) (r)

وفي وصفٍٍ آخر لما يظهر على قسمات الوجه من مكنونات النفس نجد الله

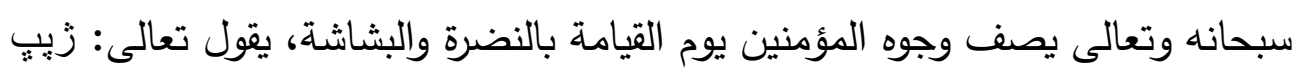

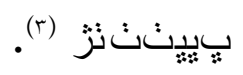
(إن هذا النص ليشير إشارة سريعة إلى حالة تعجز الكلمات عن تصويرها، كما يعجز الإدراك عن تصورها بكل حقيقتها ذلك حين يعد الموعودين بحالة من إنسات السعادة لا يشبهها حالة حتى لتتضاءل إلى جوارها الجنة بكل ما فيها من ألوان

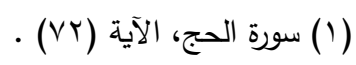

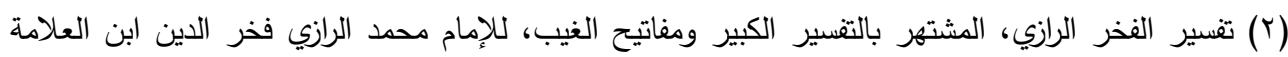

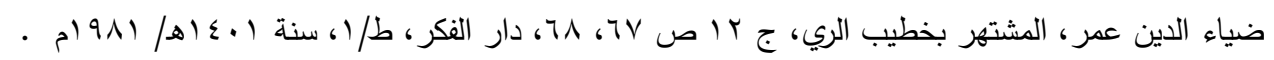

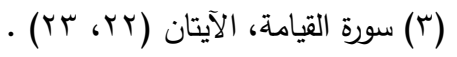


لغة الجسد بين الإسلام والدراسات التنموية البشرية وأثرها على المدعو

النعيم، هذه الوجوه الناضرة.. نضرها أنها إلى ربها ناظرة.. إلى ربها!، فأي مستوى من

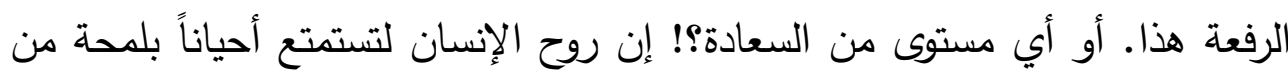

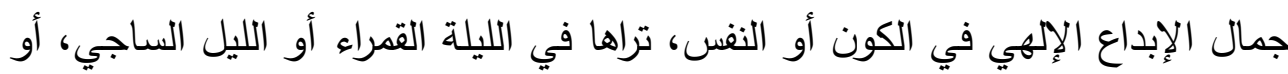

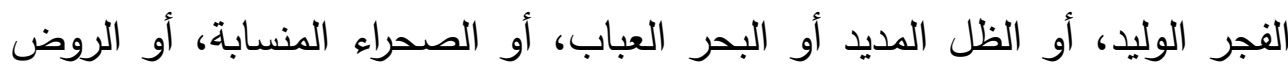

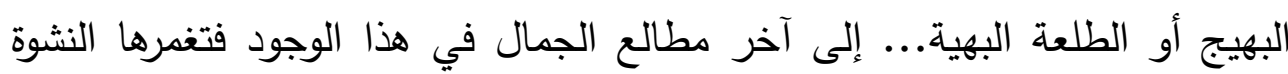

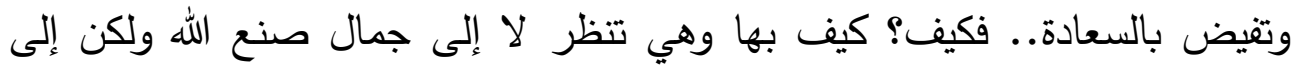

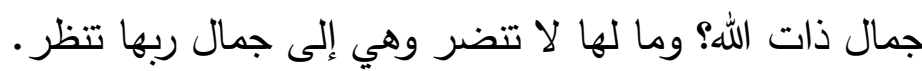

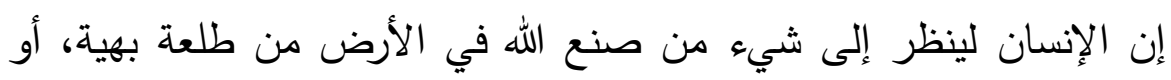

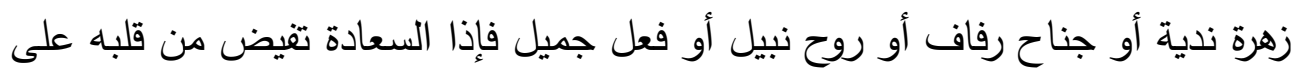
ملامحه فيبدو فيها الوضاءة والنضارة، فكيف بها حين تتظر إلى جمال الكمال مطلقاً من كل ما في الوجود من شواغل عن السعادة بالجمال!) (1).

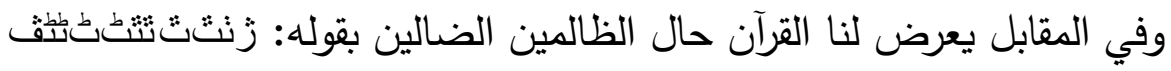

ز ز) فهذه الوجوه يظهر على ملامحها الكدر والهم والغم لخوفها مما يفعل الله بها. يقول سيد قطب . : ( هي الوجوه الكالحة المنقبضة التعيسة، المحجوبة عن النظر والتطلع بخطاياها وارتكاسها وكثافتها وانطماسها وهي التي يشغلها ويحزنها

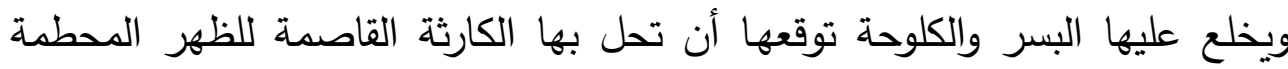

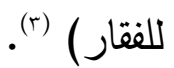

فالقرآن الكريم لا يترك هذه المشاعر إلا ويبينها، لأثرها في نفوس الناس، وليبين أنه

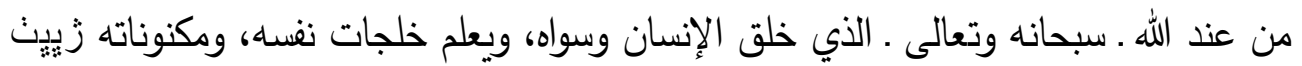

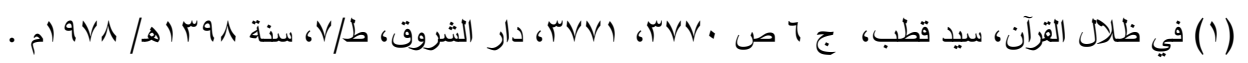

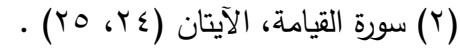

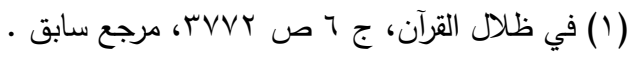


لغة الجسد بين الإسلام والدراسات التنموية البشرية و أثرها على المدعو

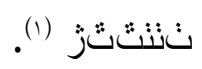

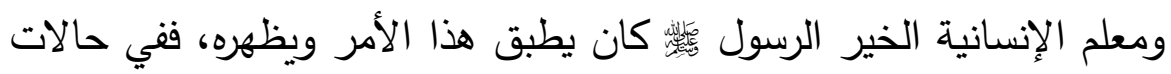

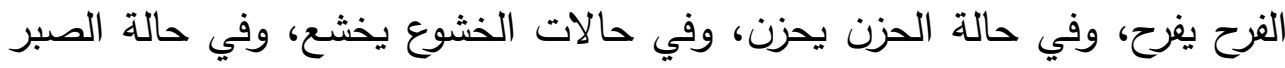

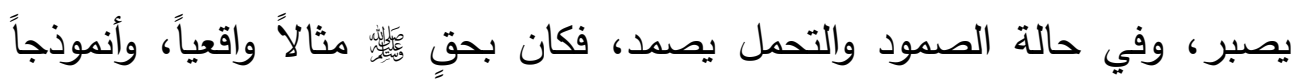

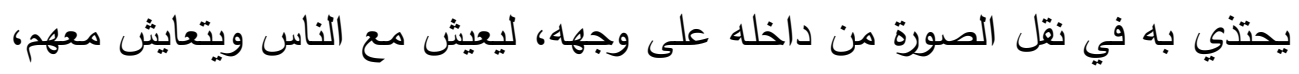

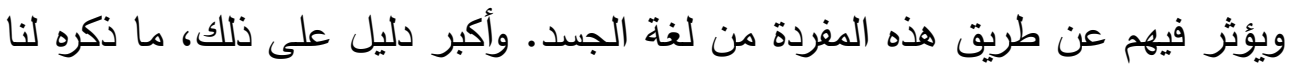

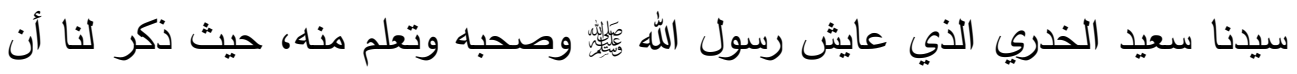

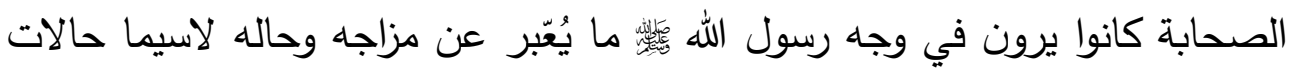

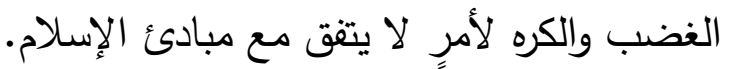

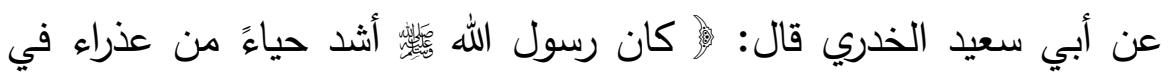

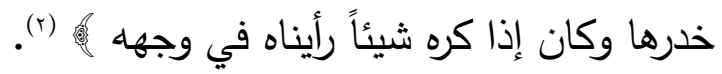

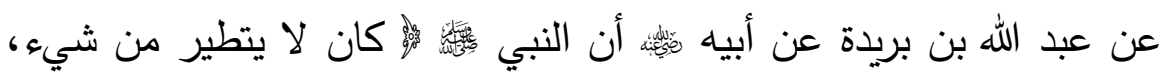

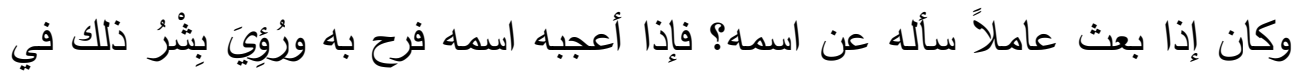

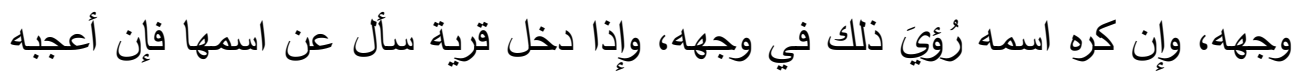

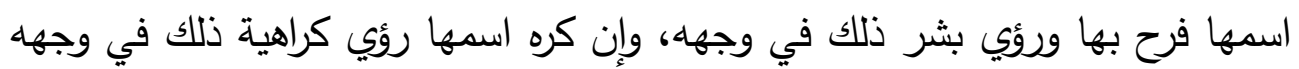

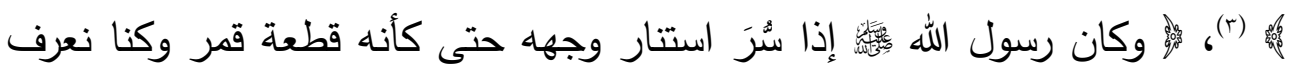
ذلك منه

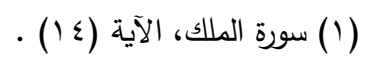

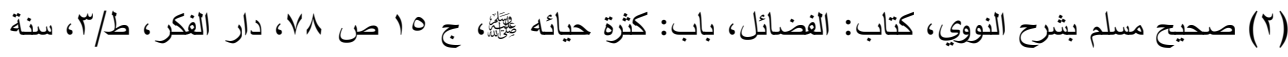

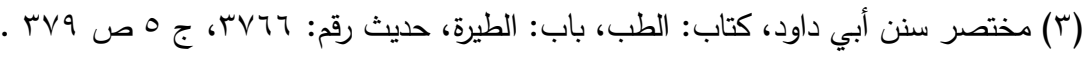

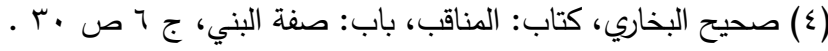


لغة الجسد بين الإسلام والدراسات التنموية البشرية وأثرها على المدعو

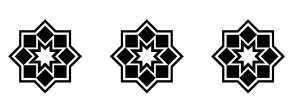


لغة الجسد بين الإسلام والدراسات التنموية البشرية وأثرها على المدعو

المبحث الخامس

\section{الثغر البسام (الابتسامة الجذابة)}

ترجع أهمية هذا التعبير الوجهي كأحد صفات اللغة الناجحة للجسد، في قوة

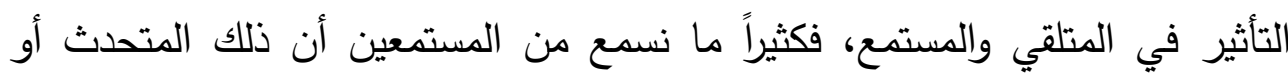

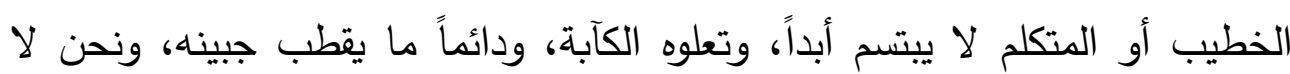

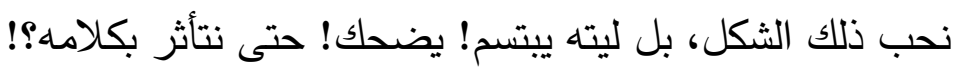

هذا الواقع المرير لبعض الدعاة في حديثهم مع الناس يرفضه كل عاقل، وكل واعي،

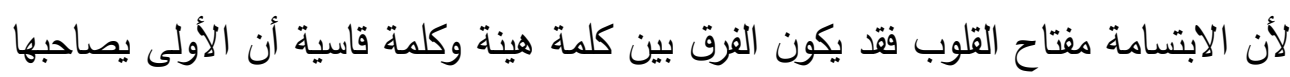
ابتسامة والثانية جافة لا بسمة فيها.

(فالابتسامة كالسنارة ما إن يراها القلب حتى يعلق بها، ولقد حدث وأن طالب

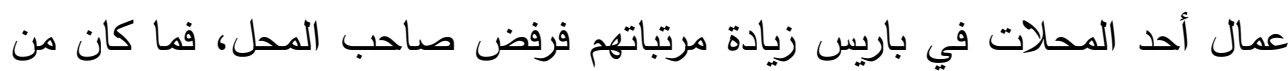

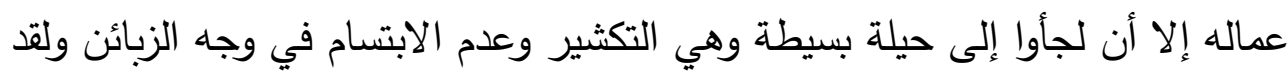

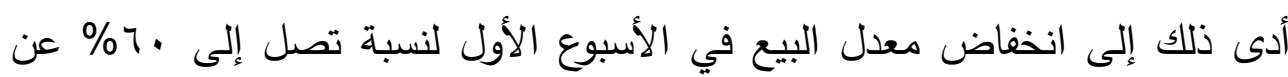

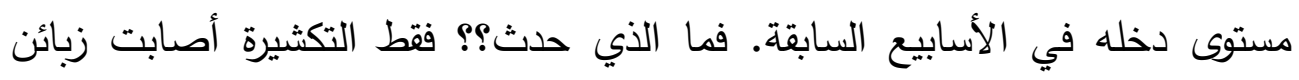
المحل بعدم الراحة، ومن ثمّ لم يجدوا لديهم الرغبة في الثراء، والسبب ابتسامة!!) (1). إذا كان هذا في البيع والثراء فما بال الذين يوجهّون الناس إلى الخير،

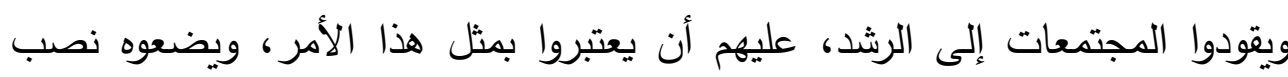
أعينهم.

ولقد أكدت خبرات وتجارب علماء النفس والاجتماع والتتمية البشرية هذه الابتسامة في

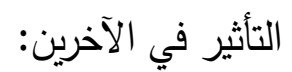


لغة الجسد بين الإسلام والدراسات التنموية البشرية و أثرها على المدعو

يقول يدل كارنجي عن الابتسامة: (إنها لا تكلف شيئاً، ولكنها تعود بالخير

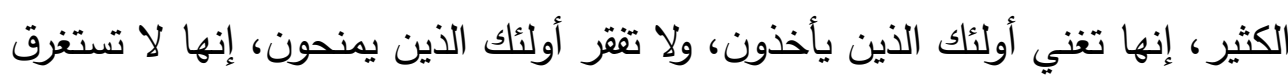

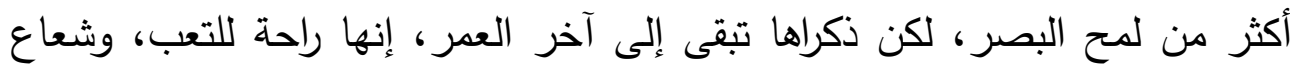
الأمل البائس، وأجمل العزاء للمحزون). ويقول د/ ماك كونيل عالم النفس الأمريكي: (إن الأشخاص الذين يبتسمون

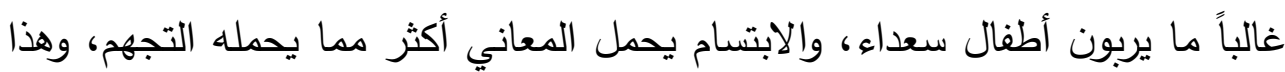

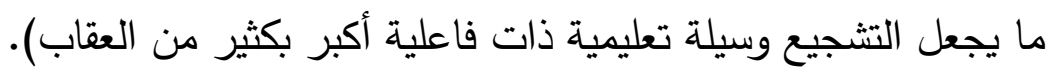
وفي المثل الصيني شخص لا يبتسم لا يصح أن يفتح متجراً!!

والابتسامة لها فوائد طيبة على المبتسم: (أثبت د. لي بيرل في دراسة علمية

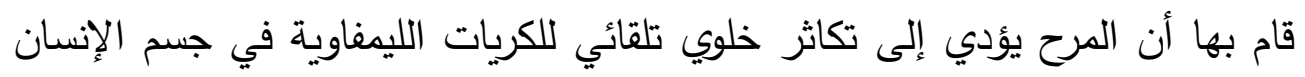

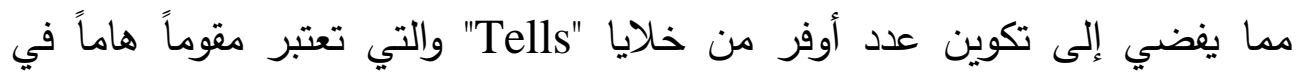
الجهاز المناعي للإنسان.

إن الابتسامة الواحدة تعادل الجري مسافة لكيلومترات وتخلص الجسم من

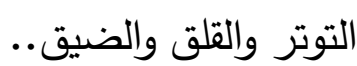

$$
\text { الابتسامة تخفف ألم المريض (•r\%) (1) }
$$

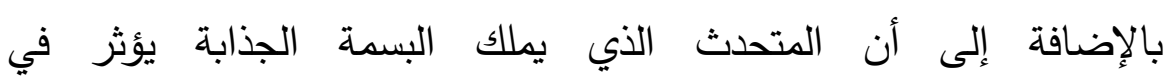
الآخرين،ويشعرون له بالارتياح والوّد.

يقول د/ إبراهيم الفقي: (الابتسامة التي ترسم على شفاه الواحد منا قادرة على لقى

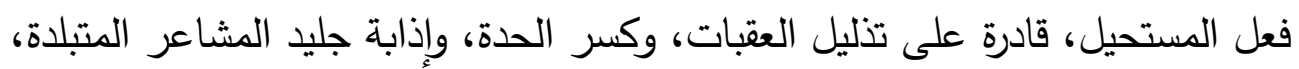


لغة الجسد بين الإسلام والدراسات التنموية البشرية و أثرها على المدعو

إن للابتسامة في كسب القلوب لتأثيرٌ وفائدة كبيرة فلا تغفلها أبداً) (1). وإذا كان هذا رأي علماء التتمية البشرية، فإن الإسلام يقرّه ويعتبره ويدعو

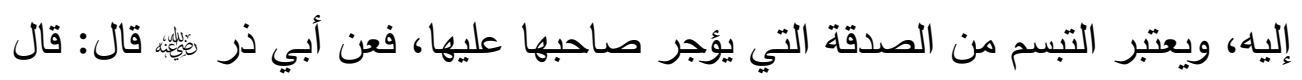
رسول الله صدقة، وإشادك الرجل في أرض الضلال لك صدقة، وبصرك للرجل الردئ البصر

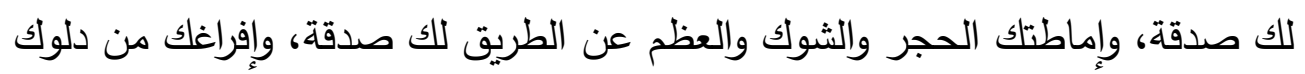
في دلو أخيك لك صدقة من (r) والإسلام كذلك ينظر إلى التبسم على أنه من المعروف الذي ينبغي للمسلم أن لا

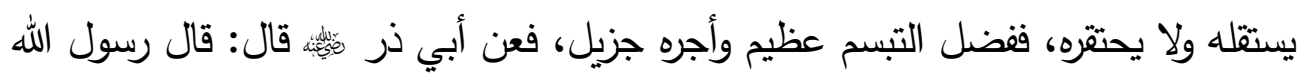

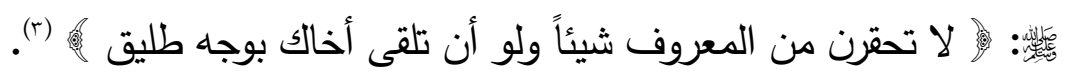

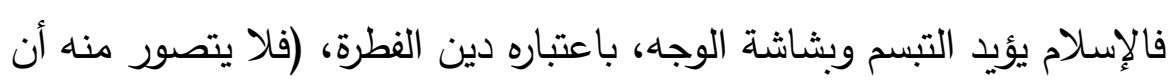

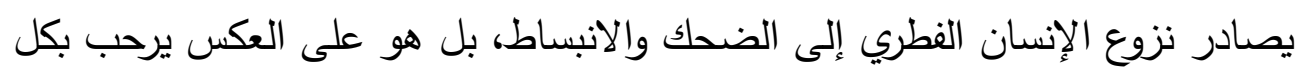
ما يجعل الحياة باسمةً طيبةً، ويحب للمسلم أن تكون شخصيته متفائلة باشة، ويكره الشخصية المكتئبة المتطيرة، التي لا تتظر إلى الحياة والناس إلا من خلال منظار

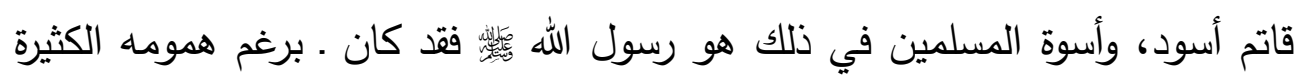

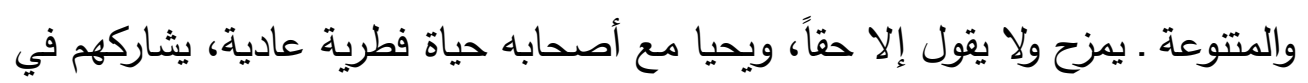
ضحكهم ولعبهم ومزاحهم، كما يشاركهم آلامهم وأحزانهم ومصائبهم).

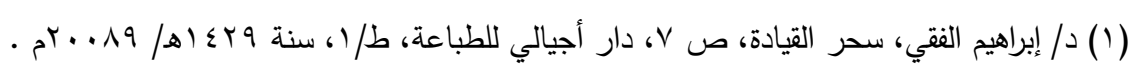

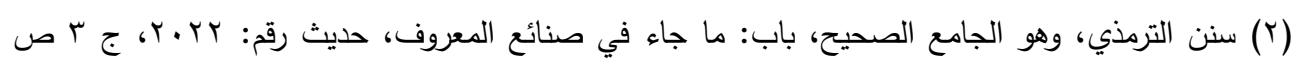

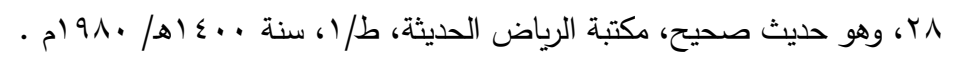

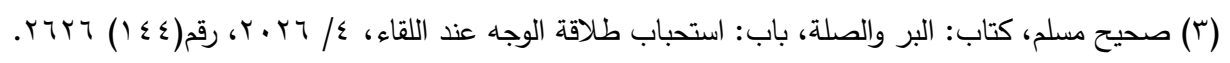


لغة الجسد بين الإسلام والدراسات التنموية البشرية وأثرها على المدعو

ولقد وجدنا أصحابه بل يصفونه بقولهم (كان من أفكه الناس) (1).

والإسلام دين الفطرة لا يكتفي عند هذا الحد بل إنه يقوم بضبط الضحك

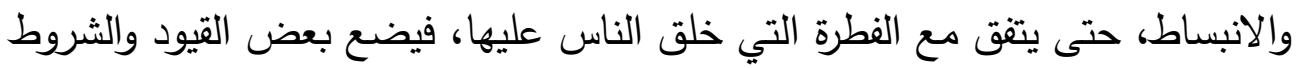
التي تضمن أن يكون في اتجاهه الصحيح، وهذه الثروط منها ل(r):

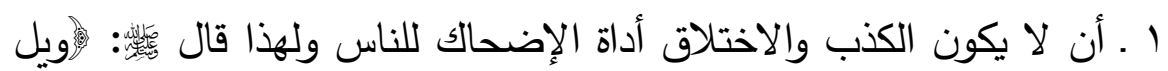

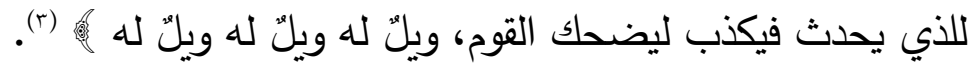
r ـ ألا يشتمل على تحقير لإنسان آخر أو استهزاء به وسخرية منه، يقول

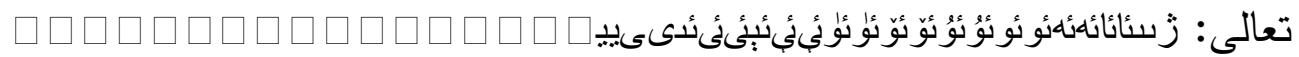
(s) $j \square \square$

وفي الحديث الصحيح: (بحسب امرئ من الثر أن يحقر أخاه المسلم) (०). وذكرت عائشة أمام البني أبس إحدى ضرائرها فوصفتها بالقصر ، فنهاها النبي

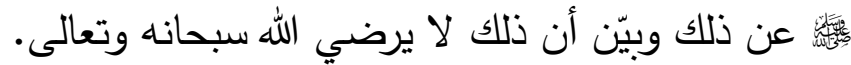

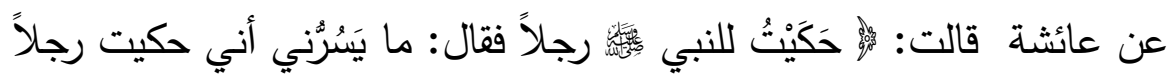

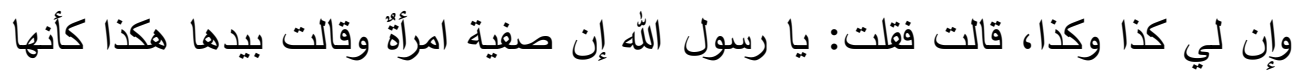

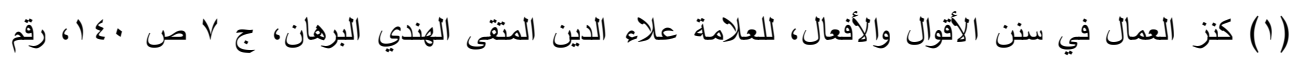

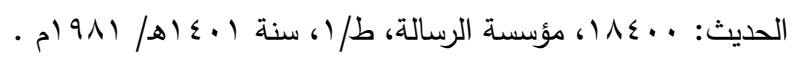

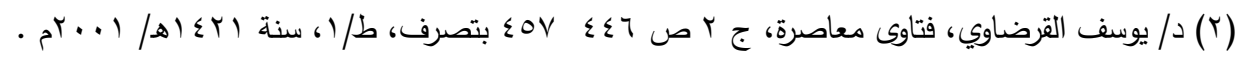

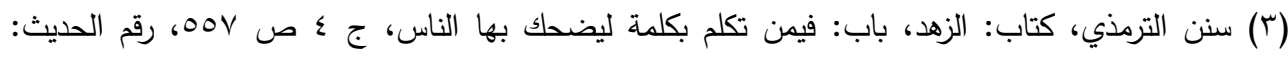

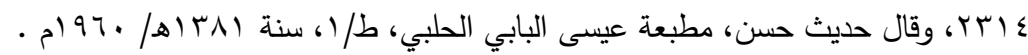

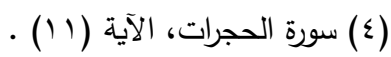

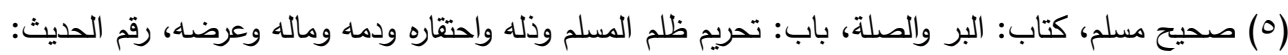
. 
لغة الجسد بين الإسلام والدراسات التنموية البشرية وأثرها على المدعو

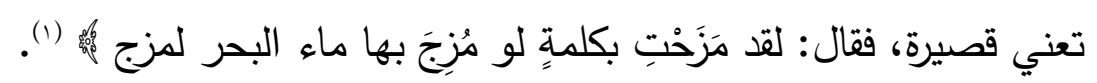

ولا يخفى على ذي نظر أن المحاكاة والسخرية ينتج عنها ضحكاً ومزاحاً.

r ـ ألا يهزل في موضع الجد ولا يضحك في مجال يستوجب البكاء، فلكل

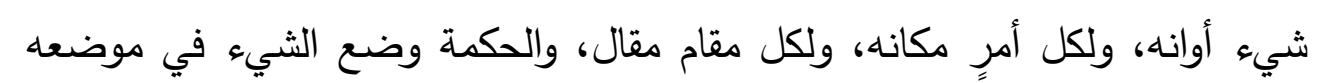
المناسب.

ومن هنا نجد القرآن الكريم عاب على المشركين أنهم كانوا يضحكون عند

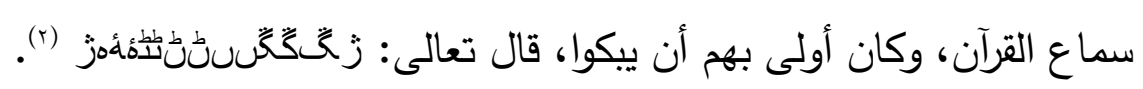

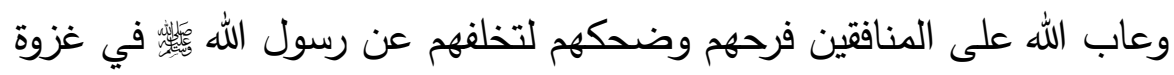

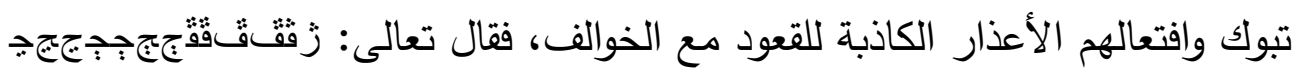

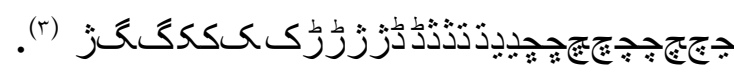

ـ ـ أن يكون ذلك بقدر معقول، وفي حدود الاعتدال والتوازن الذي تقبله الفطرة السلمية، ويرضاه العقل الرشيد، ويلائم المجتمع الإيجابي العامل، والإسلام يكره

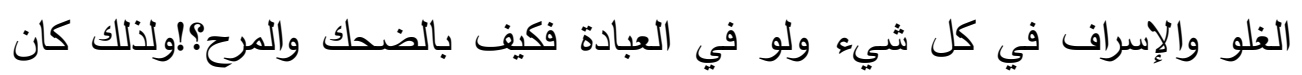

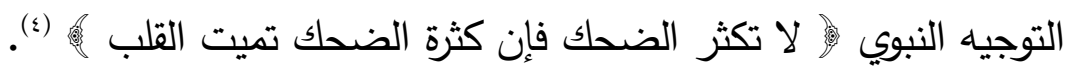
فالمنهي عنه هو الإكثار والمبالغة، والمبالغة هي التي يخشى من ورائها

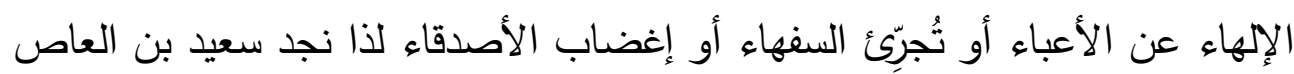

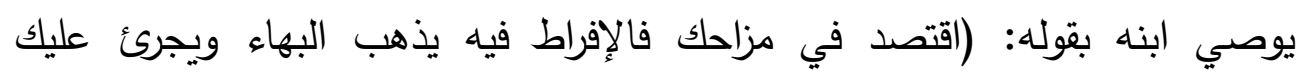

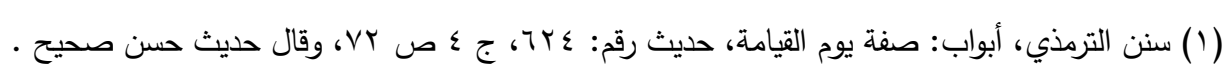

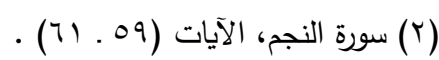

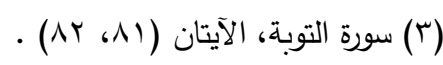

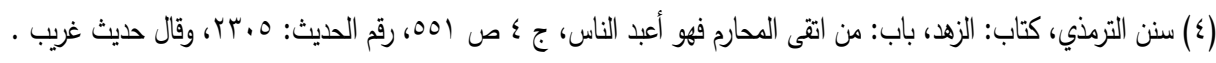

$$
\begin{aligned}
& -\mu V \varepsilon-
\end{aligned}
$$


لغة الجسد بين الإسلام والدراسات التنموية البشرية وأثرها على المدعو

السفهاء، وتركه يقبض المؤانسين ويوحش المخالطين) (1).

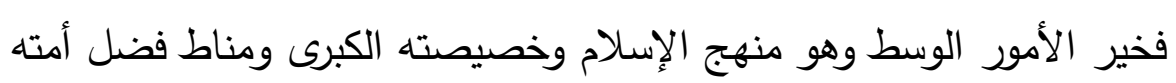

$$
\text { على غيرهم. }
$$

وقد نجد في حياتتا بعض المتشددين لا يرى أحدهم إلا مقطب الجبين، عبوس

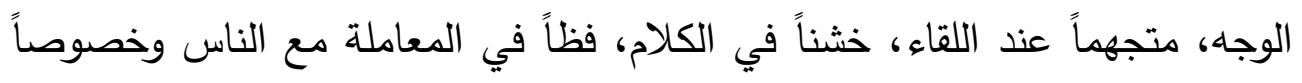

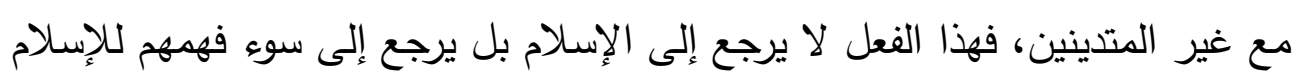

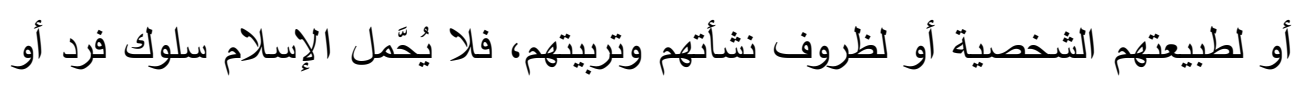
جماعة من الناس يخطئون ويصييون، والإسلام حجة عليهم وليسوا هم حجة على لإنى الإسلام إنما يؤخذ الإسلام من القرآن والسنة الثابتة.

وهذا يحتم علينا أن نفهم النصوص التي تدعو إلى الحزن والاكتئاب والتجهم

$$
\text { حتى لا نسئ فهمها وتخرجها عن الإطار الذي أريد بها. }
$$

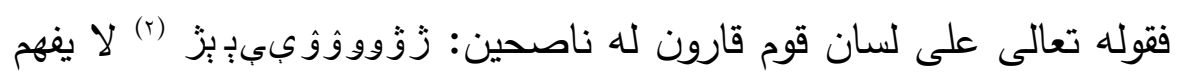

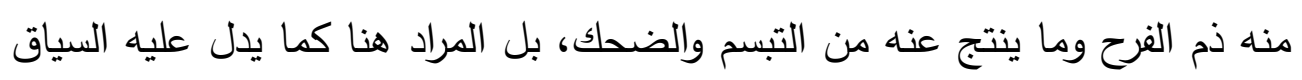

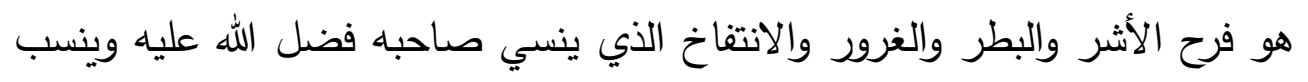

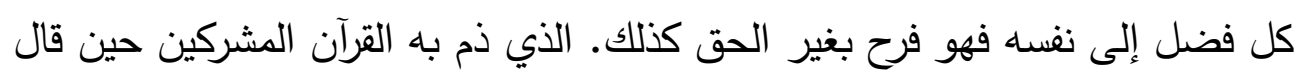

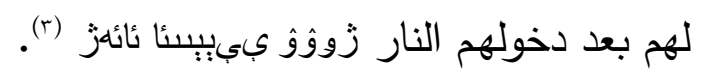

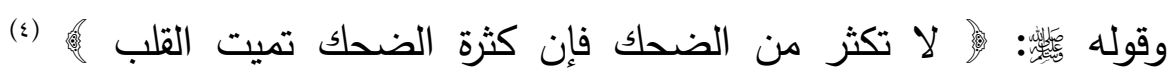
فالحديث واضح الدلالة على أن المنهي عنه ليس مجرد الضحك بل كثرته، وكل شيء

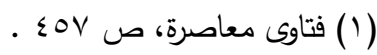

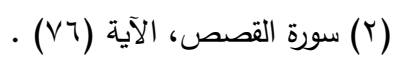

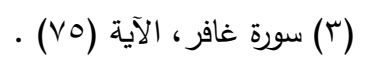

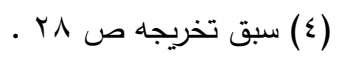


لغة الجسد بين الإسلام والدراسات التنموية البشرية وأثرها على المدعو

خرج عن حده انقلب إلى ضده.

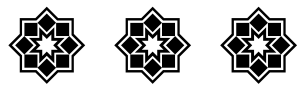

$-\mu V q-$ 
لغة الجسد بين الإسلام والدراسات التنموية البشرية و أثرها على المدعو

المبحث السادس

\section{الـوقفــــة}

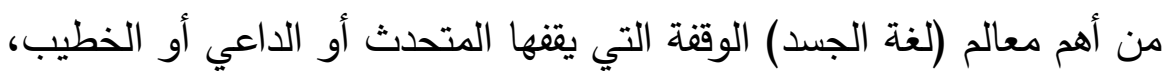

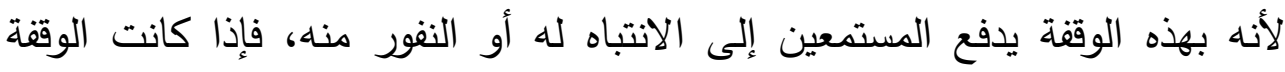

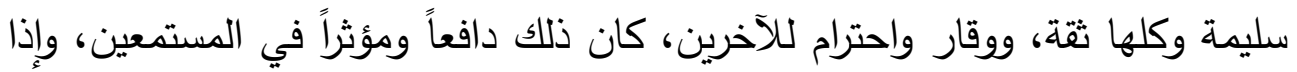
كانت الوقفة غير ذلك بأن خالطها الاستخفاف أو الاستهزاء أو الميوعة أو الغطرسة، كان الأثر سلبياً على المدعوين والمستمعين. وهذه بعض الوصايا في الوقفة لكي تكون مؤثرة:

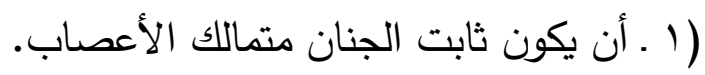

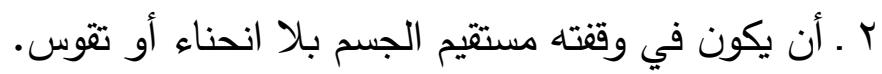
r ـ الطبيعة في الوقفة وعدم التصنع. ـ ـ ـ ـ اسب الحركات مع الكلمات.

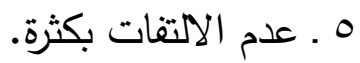
7 ـ ـ توافق حركات الوجه وتعبيرات العين. V . تجنب بعض العادات المستهنة في وقفته مثل وضع اليد على

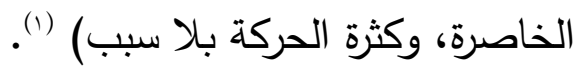
ومن شدة الاهتمام بأثر تلك الوقفة في نفوس المستمعين، نجد الأوائل اعتنوا

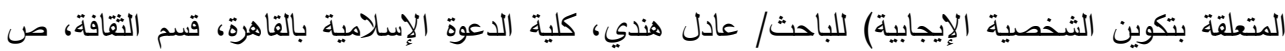


لغة الجسد بين الإسلام والدراسات التنموية البشرية و أثرها على المدعو

بها،وأولوها أهمية تُكر .

فكانوا يبرزون على أماكن مرتفعة، ويعتمدون على بعض الأشياء، حتى تزداد

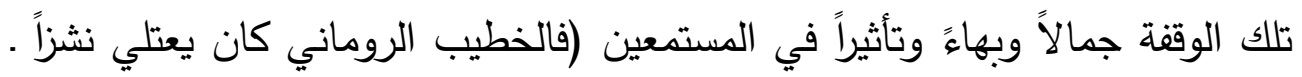

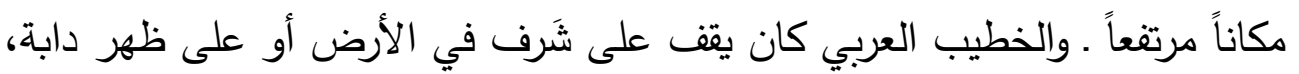

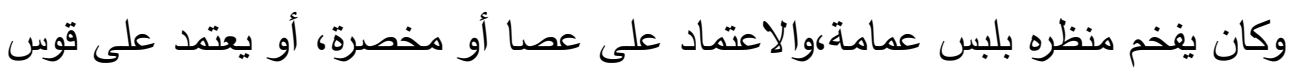

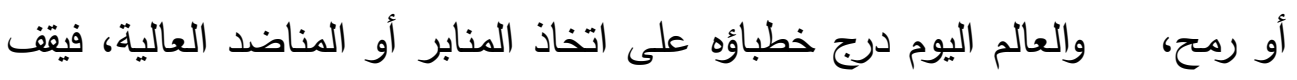

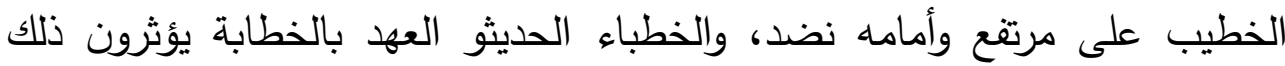
لأنهم يتوهمون أن النضد يفصلهم من الجمهور الذي يتهييونه، ولكن الخطباء المدربين

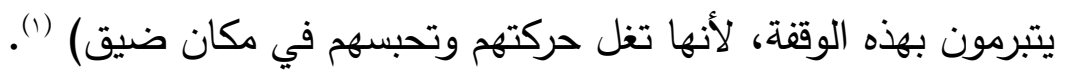
والوققة هذه لها أشكال متعددة، (فالوقفة المعتدلة الناهضة تدل على التحدي، والوقفة المنحية تدل على الحنان والثفقة والاستسلام، وانطلاق الذراع إلى الأمام ينبئ

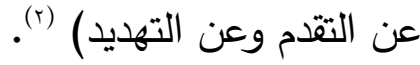
ولكن السؤال الذي يطرح نفسه في موضح الوقفة هنا؛ هل الانحناء للمستمعين

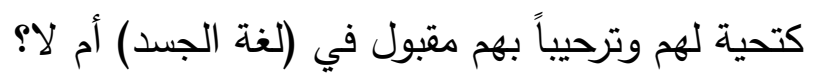
في الدراسات الخاصة بالعلماء الغربيين نجد أن الانحناء هو أحد مفردات لغة

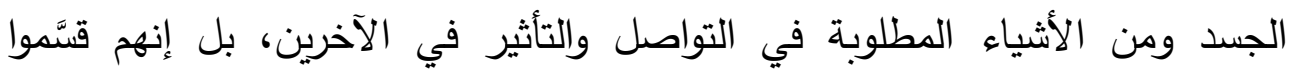

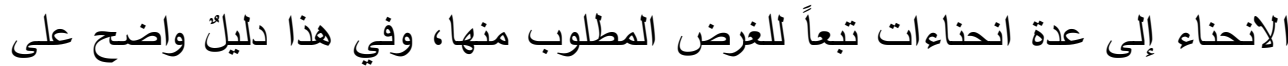
أنه أمرّ مقبول عندهم، وعادة حسنة يقبلون عليها. تقول جين مارتينت: (يُعَُّ الانحناء أداة صامتة رائعة بحق تجعلك تبدو أنيقاً، 
لغة الجسد بين الإسلام والدراسات التنموية البشرية و أثرها على المدعو

مرحاً، ومؤثراً سواء للمرأة أو الرجل) (1)

ثم تستطرد في أشكال الانحناءات ومعانيها قائلةً: (ويمكن للانحناء أن يُعبّر

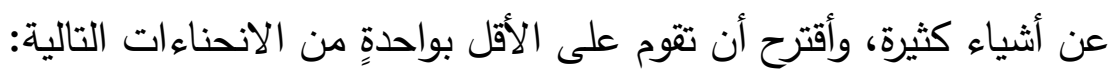

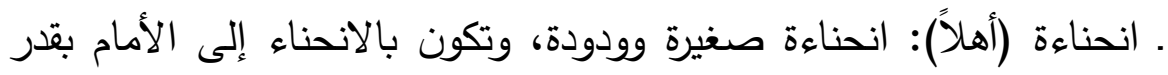

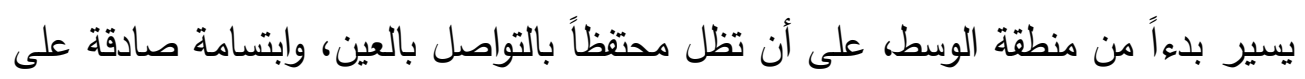
شفتيك.

ـ انحناءة (نعم): انحناءة متوسطة . صغيرة سواء بالرأس أو بالجزء العلوي من

الجسد، والعينان مغضتان، والابتسامة اختيارية.

.

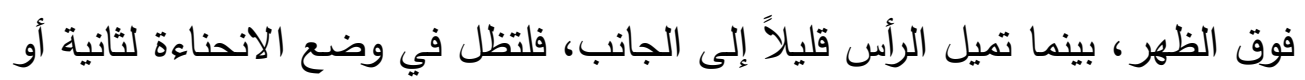
اثثين قبل أن تعود إلى وضع الاعتدال.

ـ انحناءة (الستار): انحناءة عميقة بكامل الجسد، مع مد الذراعين في حركة

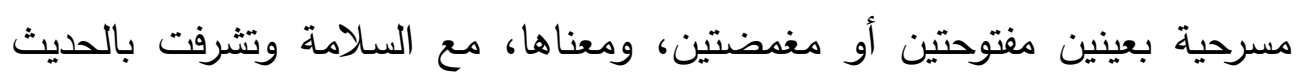

إليكم.

ـ انحناءة السخرية: دُقّ بكعبيك معاً بشدة، وانتصب في وضع الانتباه، ثم

انحن تماماً وبسرعة في شكل عسكري مسرحي ساخر ، بلا ابتسامة على الإطلاق) (r).

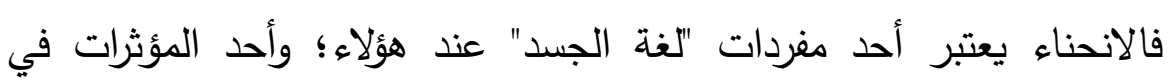

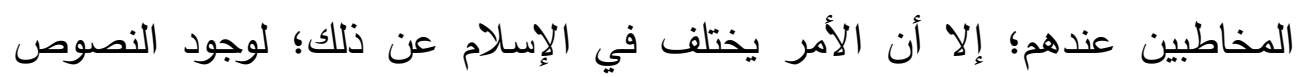

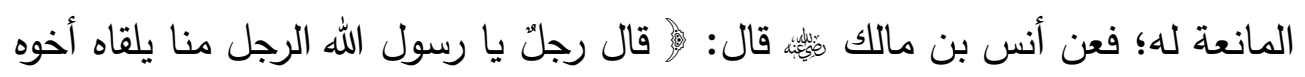

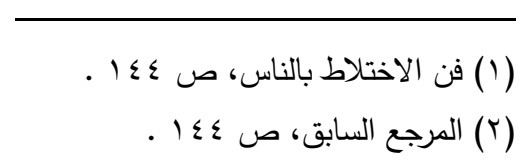


لغة الجسد بين الإسلام والدراسات التنموية البشرية و أثرها على المدعو

أو صديقه أينحني له؟ قال: لا، قال أفيلتزمه ويقبله؟ قال: لا، أفيأخذ بيده ويصافحه؟

قال: نعم (1)

ويقول الثيخ/ حسن أيوب . .: ( وقد أجاز بعض العلماء الانحناء والرد

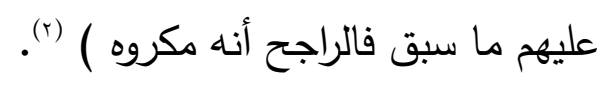

وفي الحديث إثارة إلى كراهية الالتزام والتتبيل، ولكن ليس هذا عاماً بل يجوز

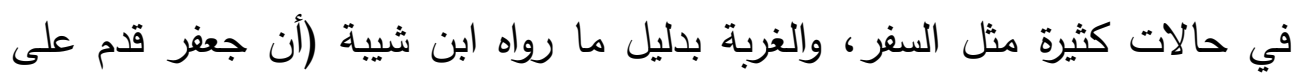

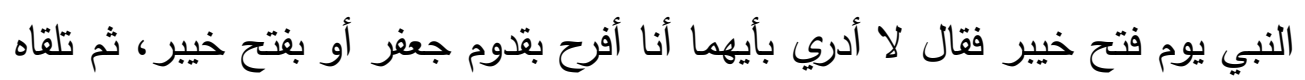
فالتزمه وقبل ما بين عينيه) (r).

ومما يجب أن يُعَلم أن العلماء الغربيين عندما يدعون إلى الانحناء، ربما لأنه

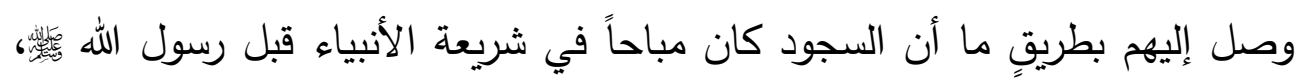

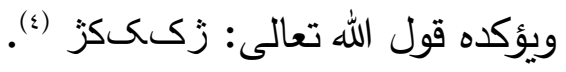

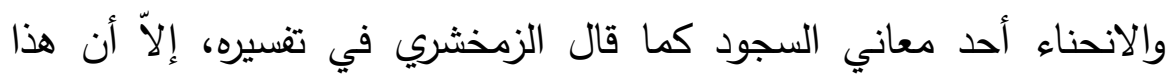

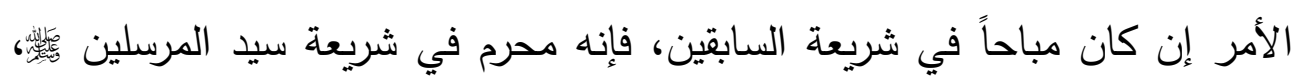

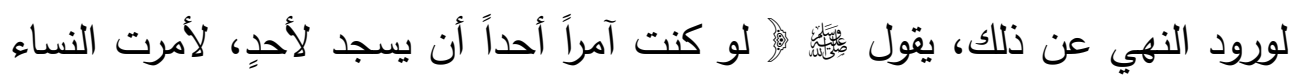

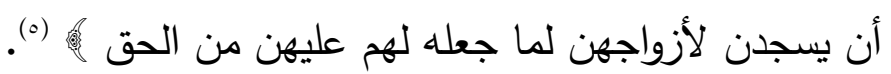

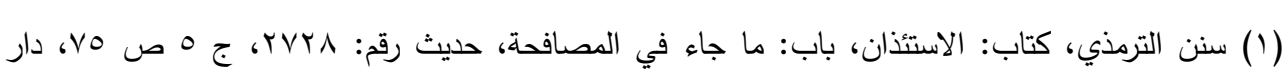

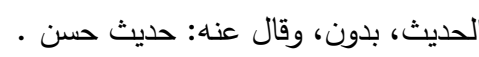

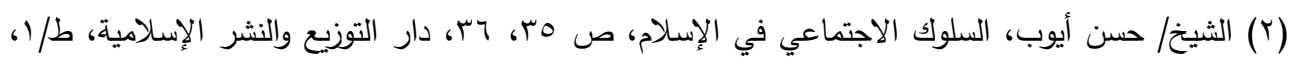

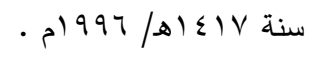
(r) المصنف في الأحاديث والآثار، للحافظ عبد الله بن محمد بن أبي شيبة الكوفي العبس، المتوفى Oبأه، كتاب:

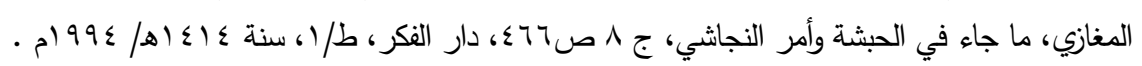

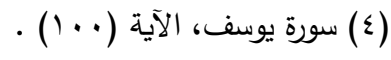
(0) مختصر سنن أبي داود، للحافظ المنذري، تحقيق: أحمد محمد شاكر، ومحمد حامد الفقي، كتاب: النكاح، 
لغة الجسد بين الإسلام والاراسات التنموية البشرية وأثرها على المدعو

فضلاً عما سبق، فإنه بالرجوع إلى أقوال المفسرين نجدهم تأولوا السجود في

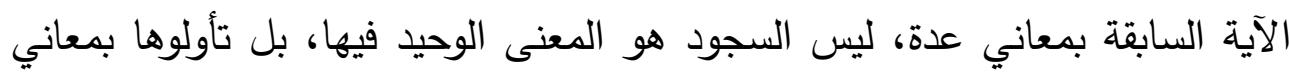

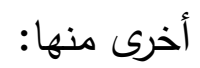

1 أن السجود يقصد به التعظيم والتكريم كعادتهم في تعظيمهم الملوك. r ـ أن السجود يقصد به التحية والتسليم، كالسلام تحية أهل الإسلام. r ـ أن السجود يقصد به المعنى اللغوي وهو الذل والخضوع أي خضعوا وذلوا لأمره وتتفيذاً لطاعته.

ـ ـ السجود هنا لله تعالى شكراً على ما أولاهم باه من نعم) (1). فالسجود في الآية إن كان حقيقياً فهو منسوخ، ومحرم في هذه الأمة، لأن السجود لا يكون إلا لله وحده سبحانه وتعالى. وأما إن كان غير حقيقي واحتمل المعاني المجازية سابقة الذكر فإن المراد يتضح والمطلوب يكون معلوماً. فيجب ملاحظة هذه الفروق بين الإسلام وغيره، رعاية للخصوصية، والتزاماً

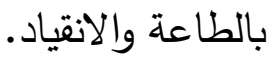

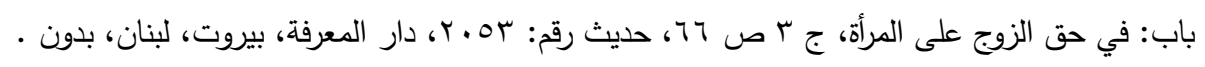

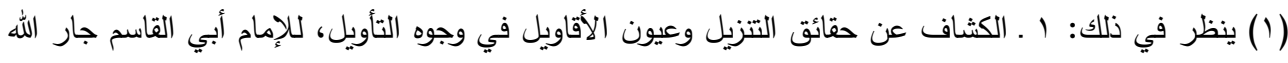

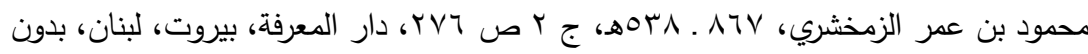

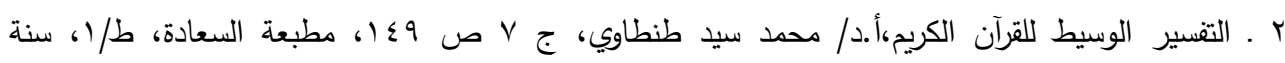

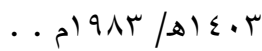

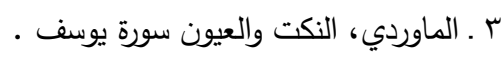


لغة الجسد بين الإسلام والدراسات التنموية البشرية وأثرها على المدعو

المبحث السابع

\section{الإثــــــارة}

أكد علماء التتمية البشرية وخبراء فنون الاتصال على ضرورة استخدام الإشارة

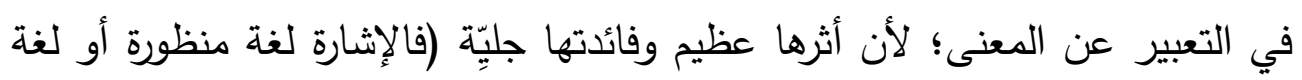
متحركة مفهومة، فإذا اقترنت الإثارة باللغة في موضعها الملائم أثرت تأثيراً عظيماً،

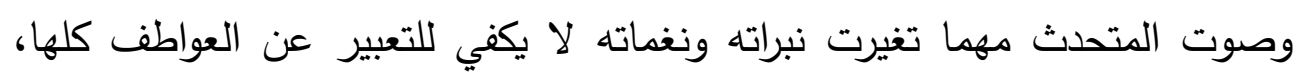

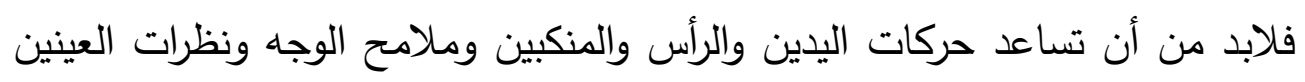

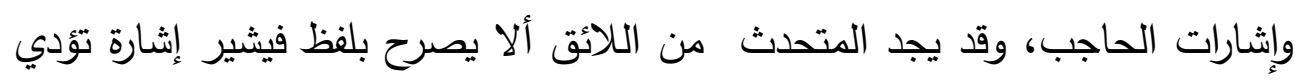

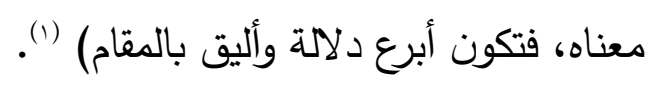

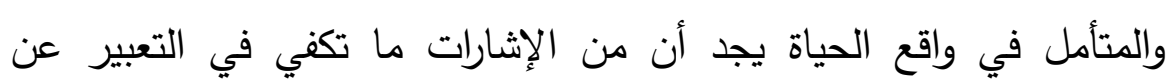

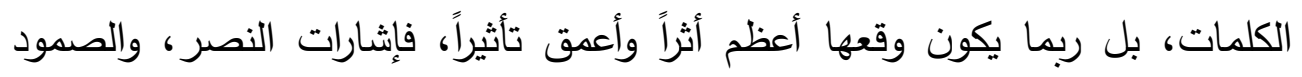

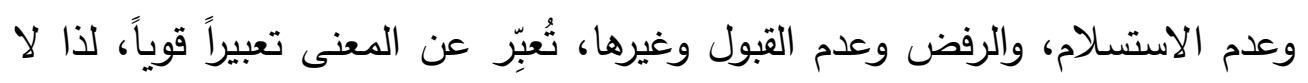

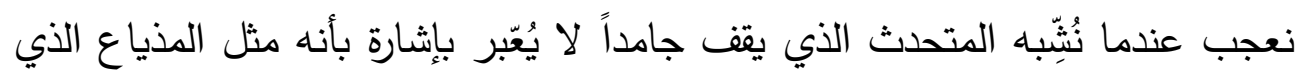
يتكلم. نعج.

والناظر في سِيَر الخطب والمتحدثين يجدهم يستخدمون الإشارة أحسن

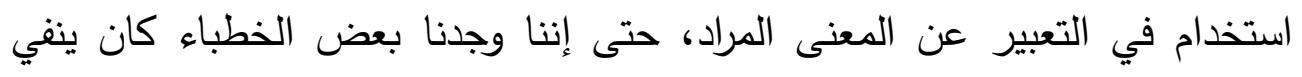
تأثير الإثارة في التعبير، لكنه اضطر إليها واستخدمها، لأن مقام التأثير يحتاجها. (ذكر الجاحظ أن أبا شِمْر كان إذا ناقش لم يحرك يديه ولا منكبيه، ولم يقلب

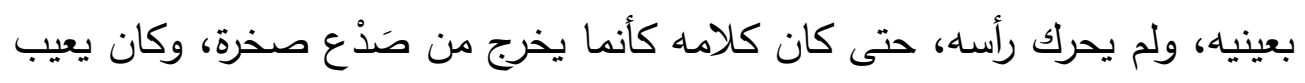
صاحب الإشارة بافتقاره إليها وعجزه عن بلوغ غايته، ويقول: ليس من المنطق أن 
لغة الجسد بين الإسلام والدراسات التنموية البشرية وأثرها على المدعو

تستعين عليه بغيره، ولكنه اضطر في مجادلة بينه وبين إبراهيم بن يسار النظام إلى إلى

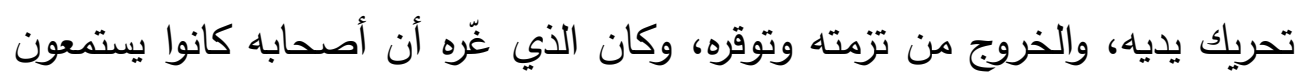

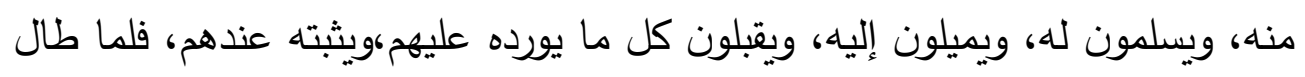

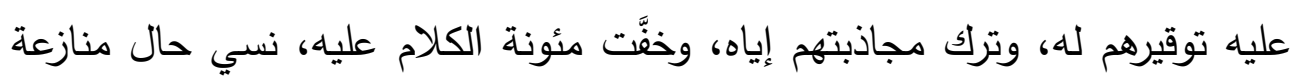

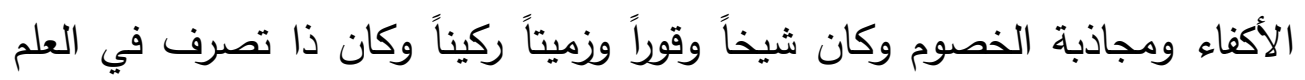

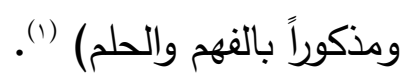

هذا وقد ذكر العلماء بعض الضوابط في الإثارة حتى تُوتي ثمارها بإذن الله

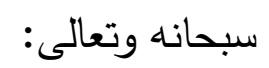

( ) يجب أن يراعي المتحدث أن الإكثار من الإثارة باليد . بغير سبب . خَطَلَ، وصرف للسامع عن الانتباه. r ـ يجب أن يضع المتحدث الإشارة في مواضعها الملائمة لها المحتاجة

r ـ أن يجعلها موافقة للمعنى وسابقة لها، فيشير ثم ينطق، وإذا اجتمعت في الجملة صفتان جعل الإثارة للأخيرة، كما لو قال: الصهيونيون نعامٌ لن يقووا على فئى

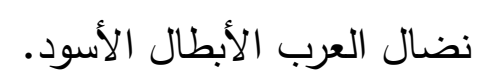

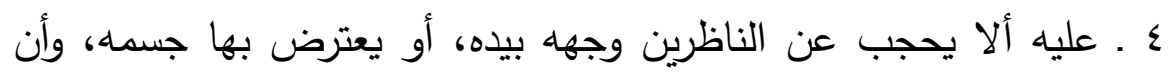

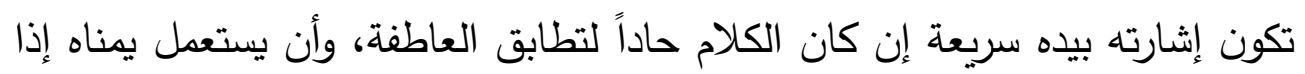
كانت رجله اليمنى إلى الأمام، والعكس. لبكس.

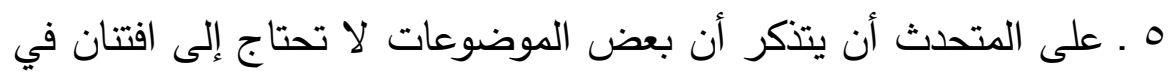

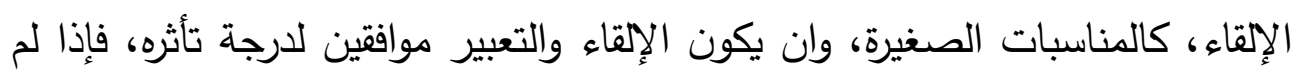

(1) البيان والتبيين، لأبي عثمان عمرو بن بحر الجاحظ، جا ص ام، دار الكتب العلمية، بدون . $-r \wedge r-$ 
لغة الجسد بين الإسلام والدراسات التنموية البشرية و أثرها على المدعو

يكن انفعاله قوياً فليتكلم كما يحس.

7 ـ تفادي الإثارة إلى مجموعة معينة طوال الخطبة وتوزيع النظرات على الجميع.

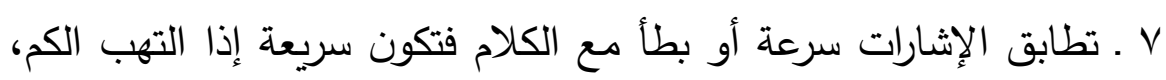

هادئة إذا هدأ) (1)

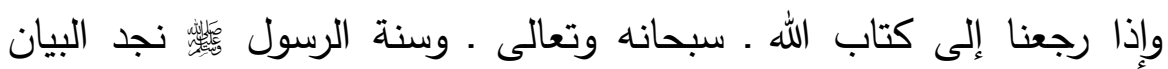
الثافي في أهمية استخدام الإثارة في التعبير والتوضيح.

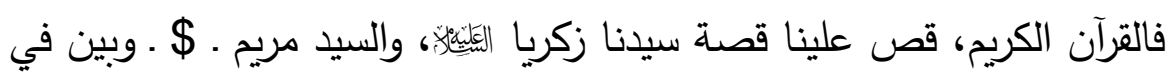

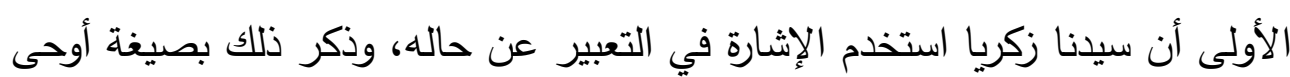

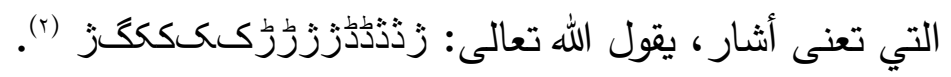

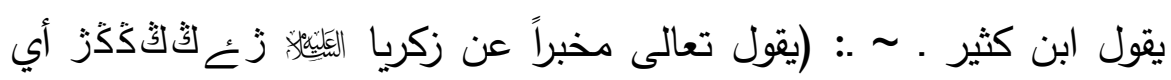

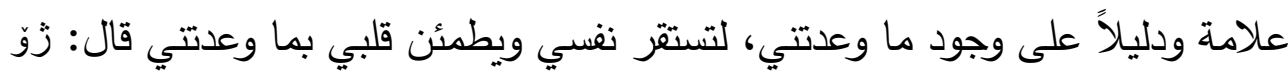

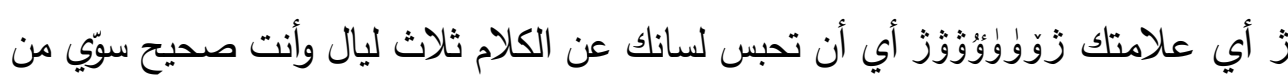
غير مرض ولا علة.

قال ابن زيد بن أسلم كان يقراً ويسبح ولا يستطيع أن يكلم قومه إلا إشارة زؤو

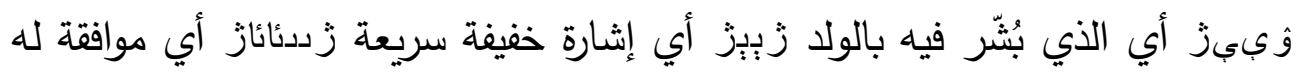
فيما أمر به في هذه الأيام الثلاثة زيادة على أعماله شكراً لله على ما أولاه.

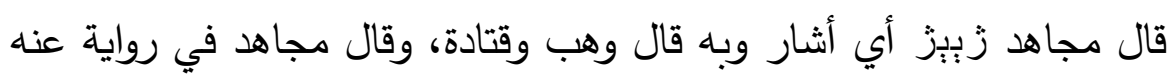
زُبنز أي كتب لهم في الأرض وكذا قال السدي) (r).

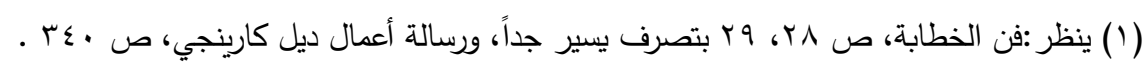

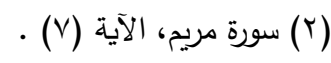

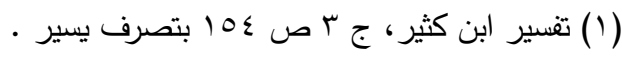


لغة الجسد بين الإسلام والدراسات التنموية البشرية وأثرها على المدعو

ولا يخفى علينا استخدام سيدنا زكريا للإشارة للتعبير عما يريده، سواء كان هذا بالإثارة المجردة، أو بالإثارة المفضية إلى الكتابة كما جاء في رواية مجاهد والسدي. وبيّن القرآن أهمية الإثارة في التعبير عن المعنى من خلال قصة السيدة مريخ

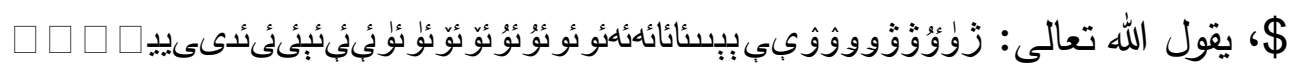

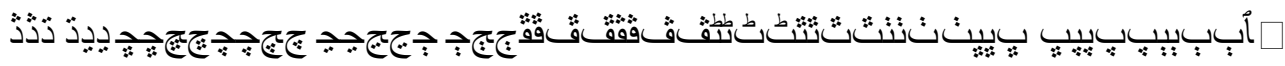

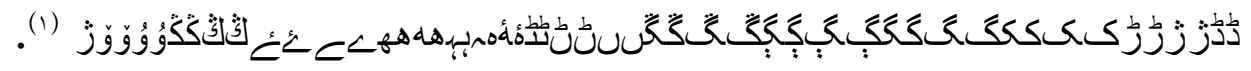
يقول ابن كثير . .: (... وقال ابن جرير عن قتادة قوله زُُّّز قال كانت

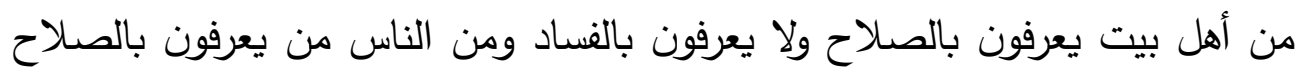

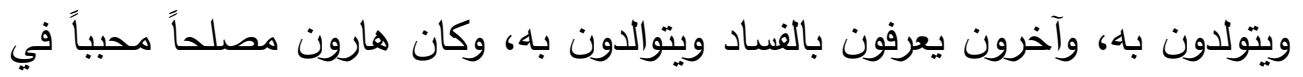

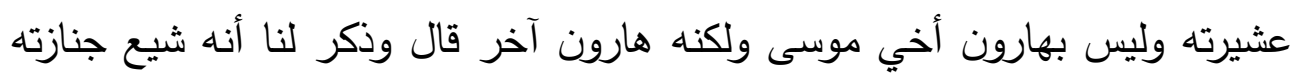

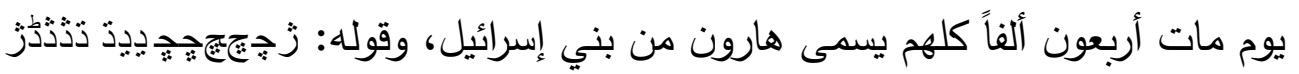

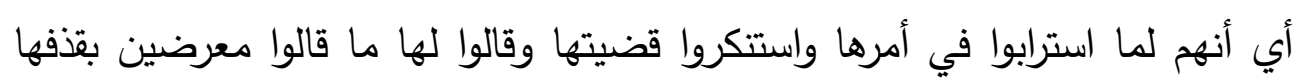

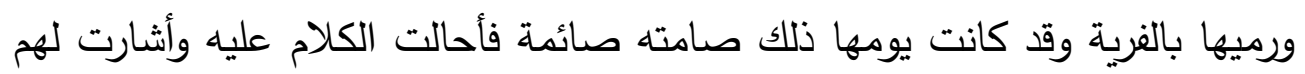

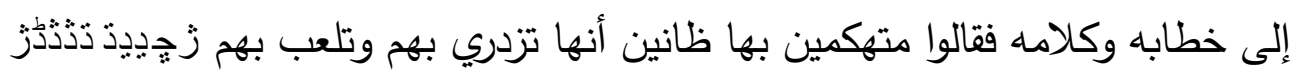

قال ميمون بن مهران زجيَّز قالت كلموه فقالوا على ما جاءت به من الداهية

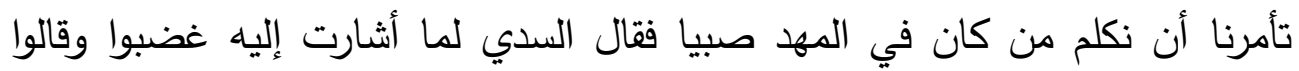

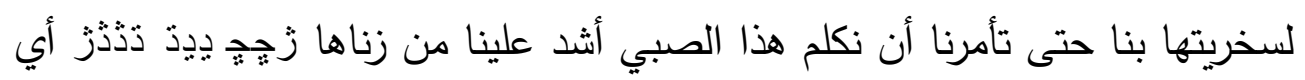

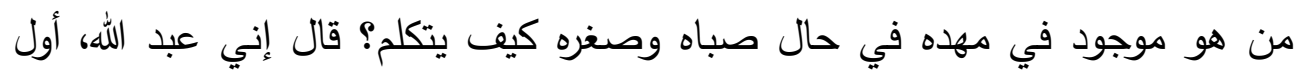

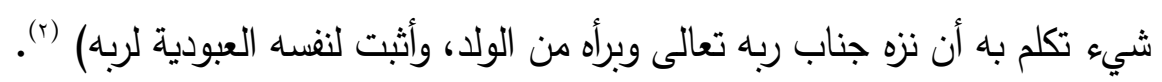

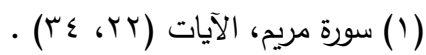

(r) تفسير القرآن العظيه، للحافظ أبي الفداء إسماعيل بن كثير القرشي الدمشقي،ج r ص ب rابrالمجلد 
لغة الجسد بين الإسلام والدراسات التنموية البشرية و أثرها على المدعو

وعند الرجوع إلى سنة سيد المرسلين

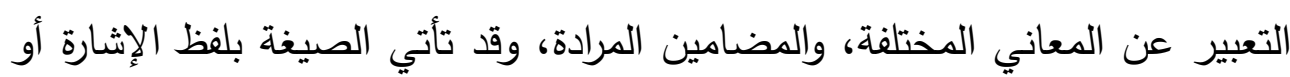

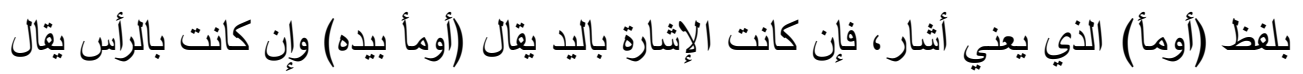

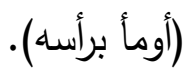

وعند التأمل في سنة الهادي البشير \$لمُ نجد أن الإشارة حملت المعاني المختلفة، وصوّرت المضامين المتعددة من الإجابة، والدعوة إلى الثبات في المكان،

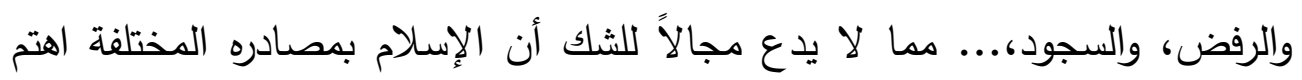
بالإثارة كأحد المؤثرات في نفسية المستمعين. وفيما يلي بعض الثواهد من سنة رسول الله

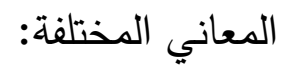
1 ـ ـ معنى الدعوة إلى الثبات في المكان وعدم التغير عنه.

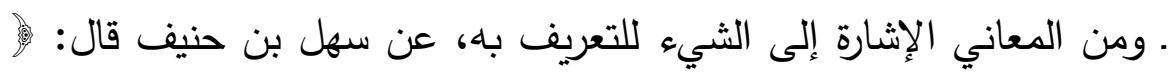

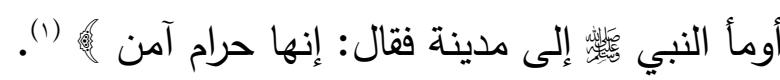
ـ وتحمل معنى السجود وهو المرفوض شرعاً ولا يكون إلا لله سبحانه وتعالى، حدثا أبو معاوية عن ابن سيرين أنه ذكر عنده عثمان بن عفان قال رجل: إنهم

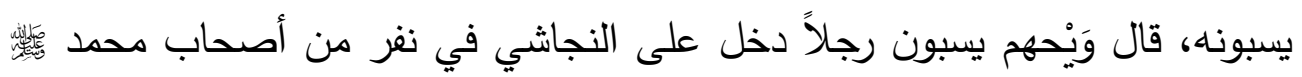

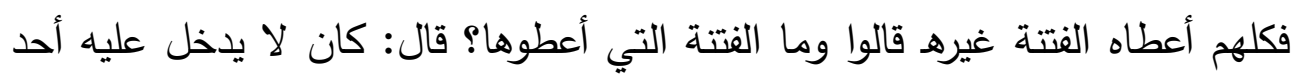

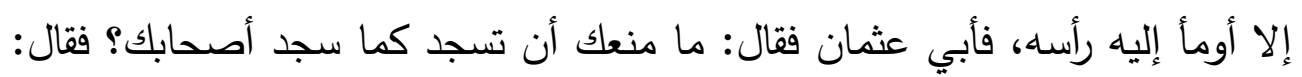

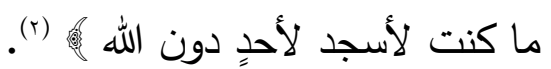

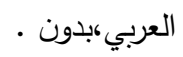

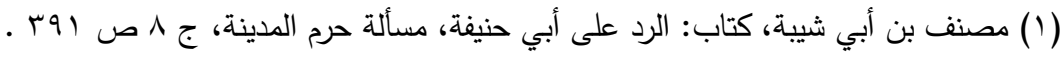

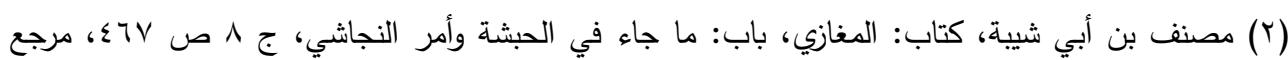


لغة الجسد بين الإسلام والدراسات التنموية البشرية و أثرها على المدعو

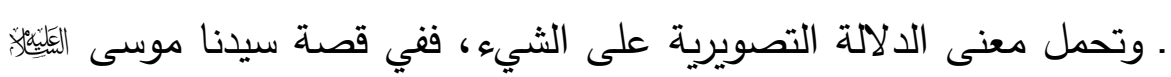

مع الخضر كما رواها البخاري مثل لنا الراوي ما حدث بين سيدنا موسى العيلئلة وسيدنا

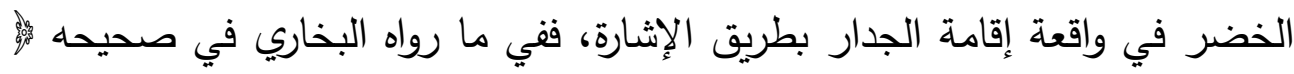
لقيا غلاماً فقتله، قال يعلى: قال سعيد وجد غلمانداً لئل يلعبون فأخذ غلاماً كافراً ظريفاً

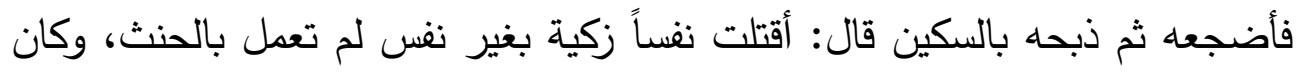

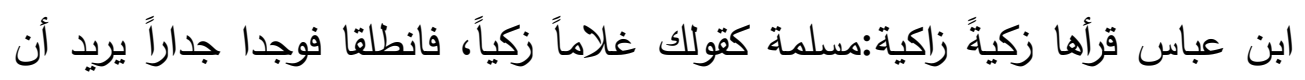

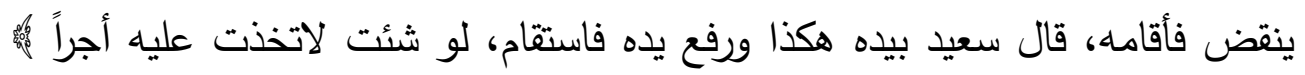

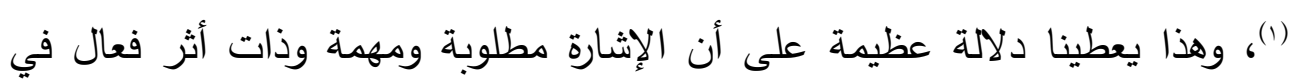

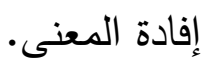

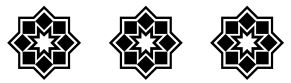


لغة الجسد بين الإسلام والدراسات التنموية البشرية و أثرها على المدعو

المبحث الثامـن

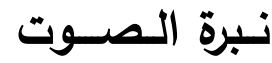

نبرة الصوت عليها عاملُ كبير في الإقتاع، لأن الصوت بنغماته المختلفة،

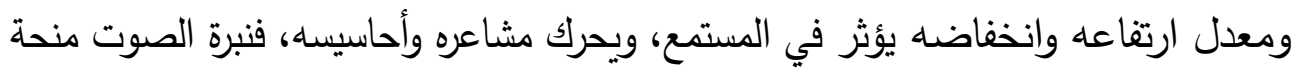

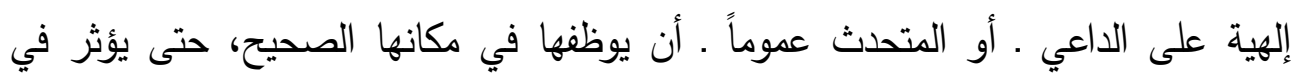
الستمعين، ويقوم بواجب شكر هذه النعمة التي وهبه الله إياها.

وعند الرجوع إلى الدراسات التتموية البشرية الحديثة نجدها تتفق مع هذا

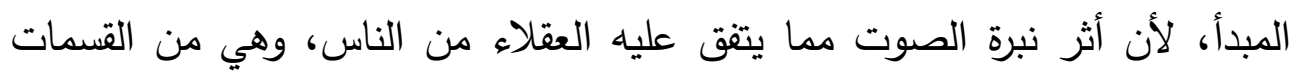

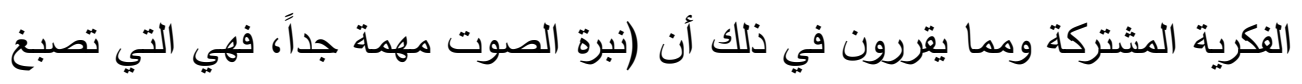
الكلمات بالصبغات المطلوبة، كالاهتمام واللامبالاة، والسخرية، والتهكم، أو الخطورة،

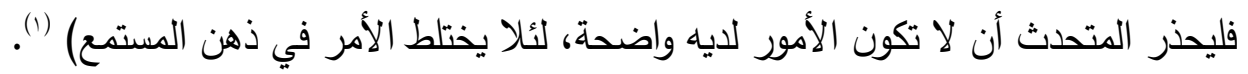
فعلماء التتمية البشرية يدعون إلى تتوع نبرة الصوت في الحالات المختلفة،

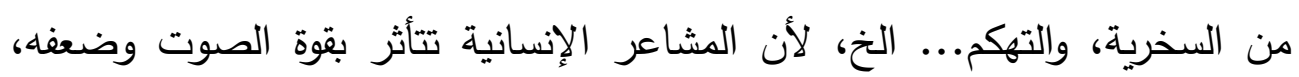
ورفعه وخفضاه، وتفخيمه، وترقيقه، وترعيده، وتطريبه ....

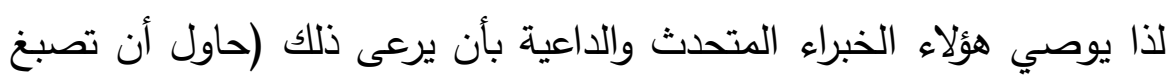

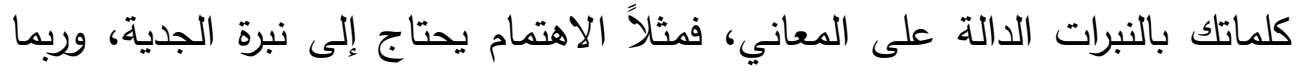

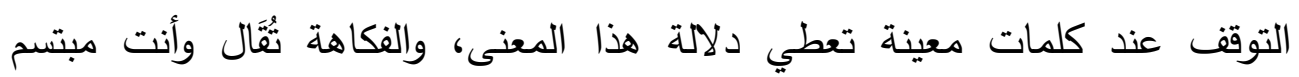
ضاحك، فلا يتصور أحدٌ يلقى بطرفة وهو عبوس مقضب الجبين، والأحاديث العلمية

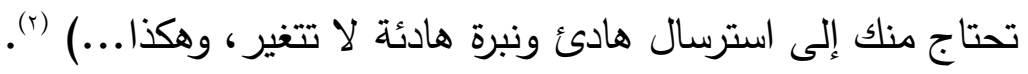

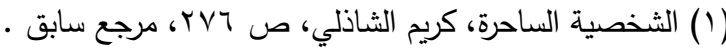

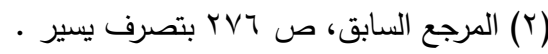


لغة الجسد بين الإسلام والدراسات التنموية البشرية و أثرها على المدعو

ونحن نحترم ونقّر هذا الكلام الطيب، ونزيد عليه أن الإسلام وضّحه وبيّنه واعتبر اتباعه وتنفيذه بنية صادقة طاعة لله ولرسوله لهإ: اللذين يدعوان العبد لابتكار أفضل الوسائل والأساليب واتباعها في هداية الناس إلى رب وبله العالمين. فمعلم البشرية كُّك كان يراعي الحال في كلام ونبرة صوته، ففي الأمور التي تستحق الهدوء والإقناع والتبسط يتكلم بنبرة هادئة لينّة يشوبها العطف والحنان

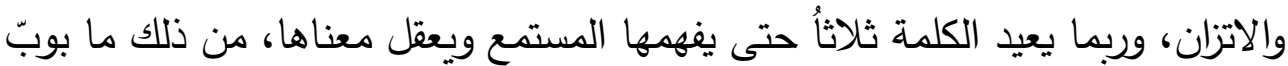
له الإمام البيهقي . . تحت عنوان: باب ما يستحب من تبيين الكلام وترتيله وترك داني (العجلة فيه) (1)

وجاء من سنة رسول الله كُ ما يؤكد ذلك؛ فعن عائشة ـ > ـ قالت: ( كان كلام رسول الله

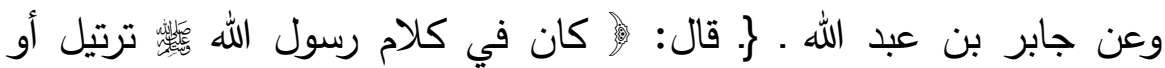
ترسيل (r)

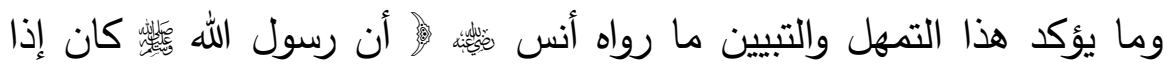

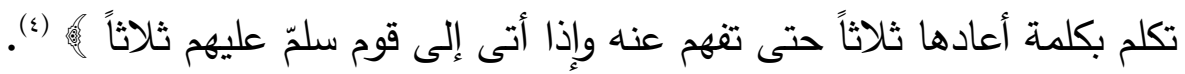

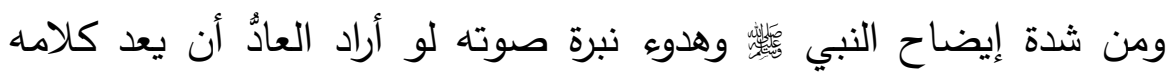

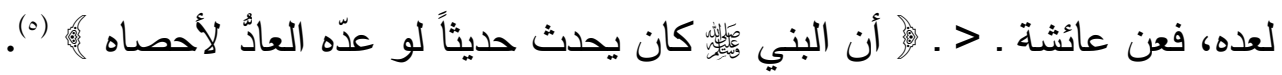

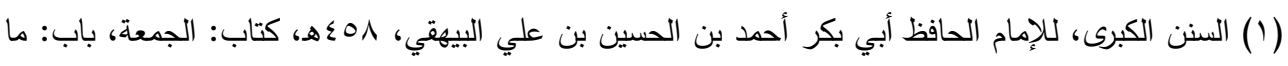

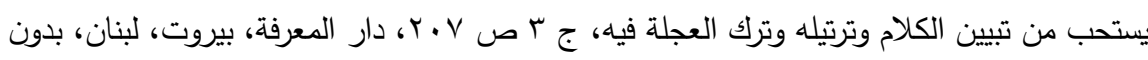

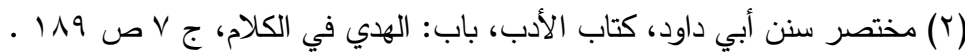

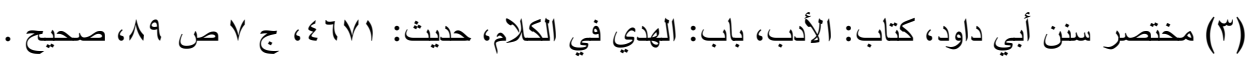

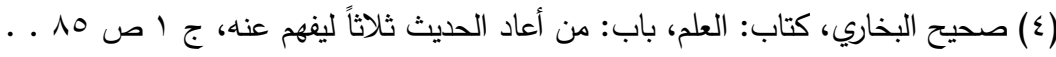

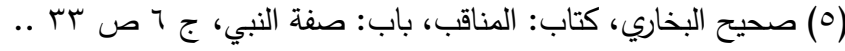

$$
\begin{aligned}
& -r \wedge q-
\end{aligned}
$$


لغة الجسد بين الإسلام والدراسات التنموية البشرية و أثرها على المدعو

وهذا التكرار من النبي

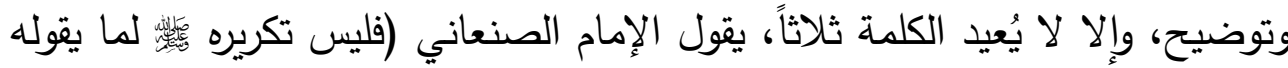

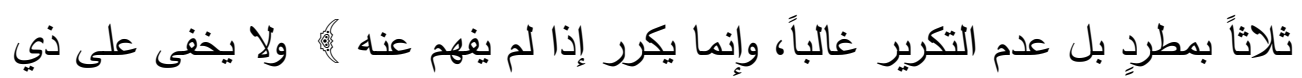
لبّ أن نبرة الصوت في مثل ذلك تكون هادئة مرتلة غير متعجلة ولا متشنجة.

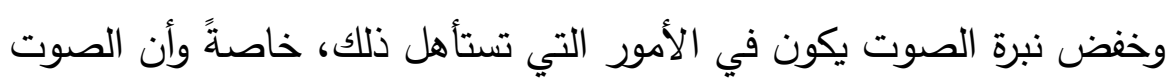

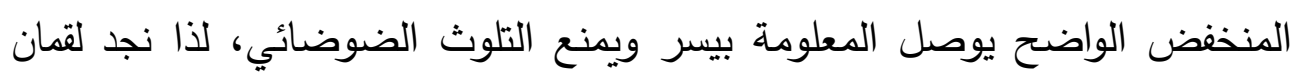

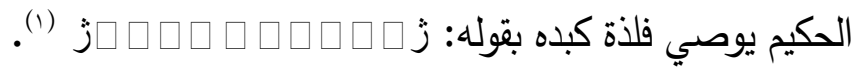

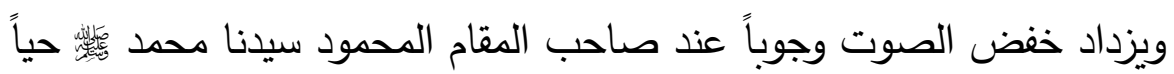

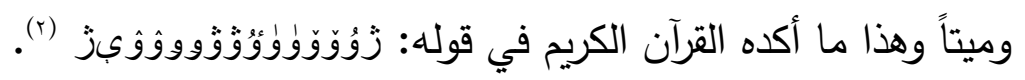

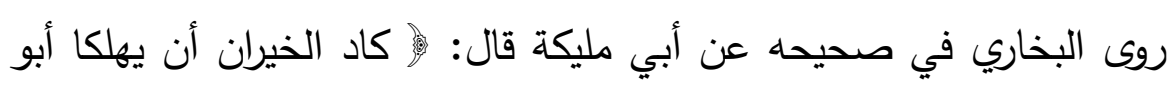

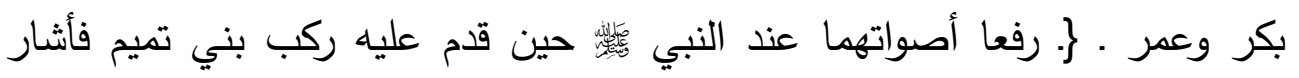

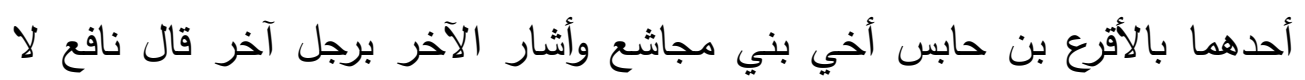

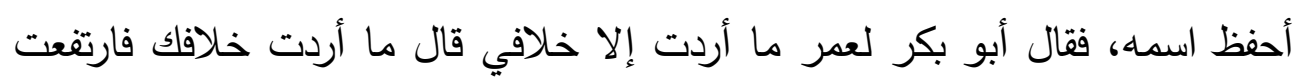

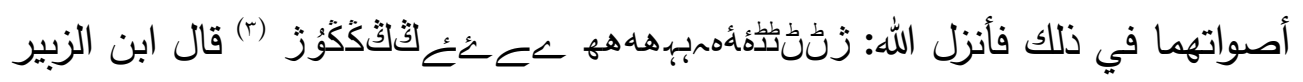

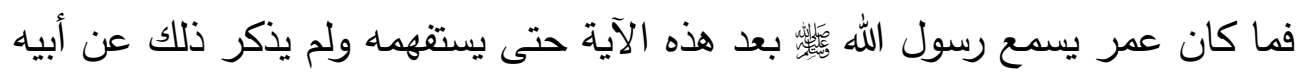

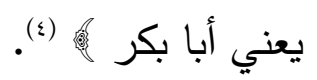

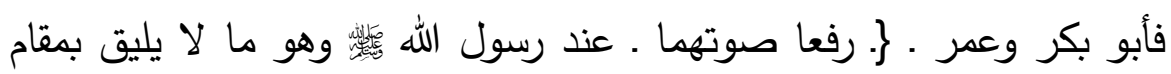

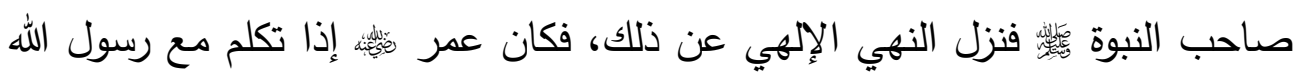


لغة الجسد بين الإسلام والدراسات التنموية البشرية وأثرها على المدعو

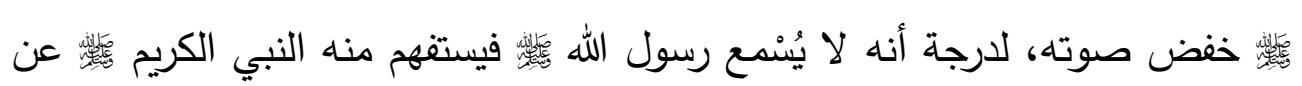

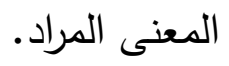

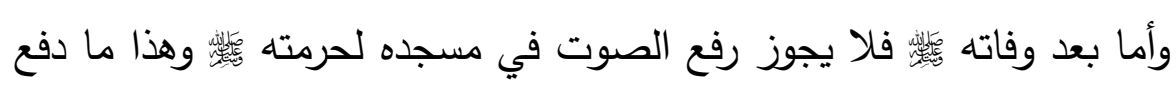

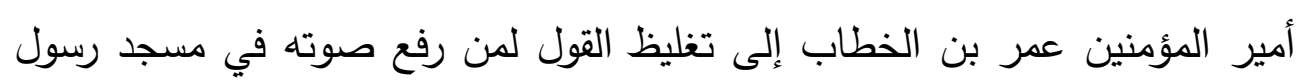
الله

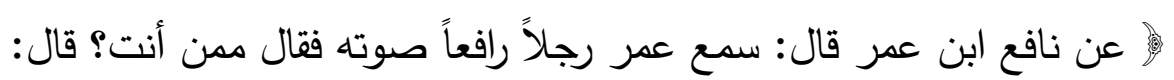

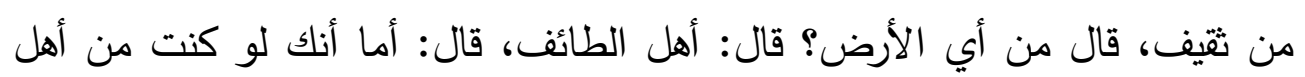

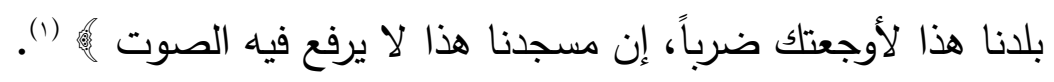
ومعلم البشرية ؤس يغيّر من نبرة صوته إلى الحدة والثدة والارتفاع إذا كان الأمر يستأهل ذلك، ويتطلب إيقاظ المشاعر الإنسانية والضرب على على أوتارها

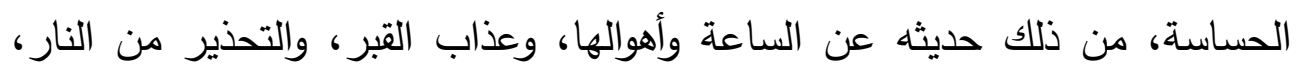

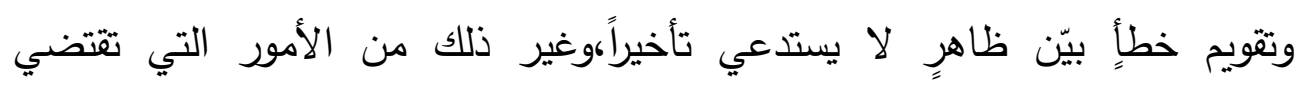

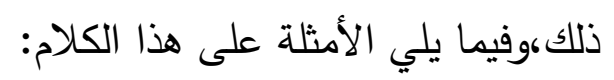

ا ـ الحديث عن الساعة وأهوالها: روى الإمام أحمد في مسنده عن جابر بن الهن

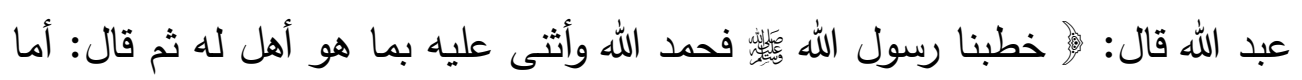

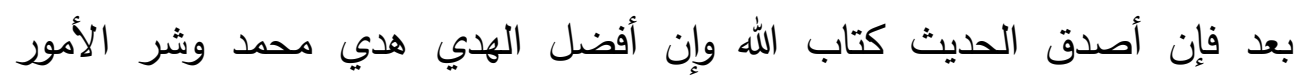

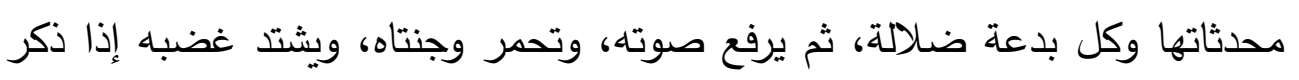

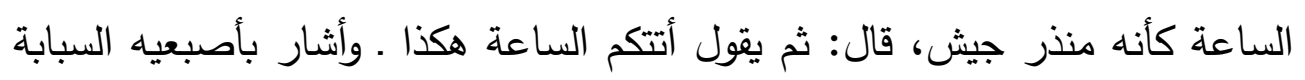

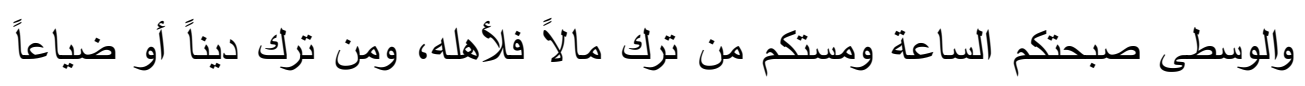

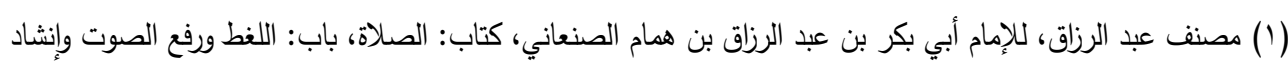

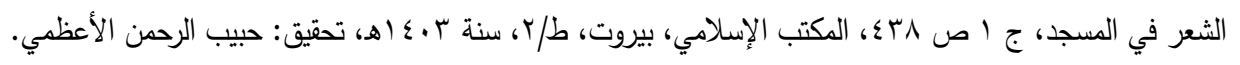


لغة الجسد بين الإسلام والدراسات التنموية البشرية و أثرها على المدعو

$$
\text { فإليّ وعليّ مان (1). }
$$

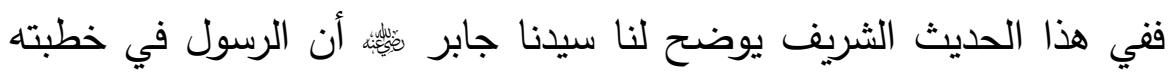
إذا ذكر الساعة يرفع صوته وتحمر وجنتاه، ويشتد غضبه كأنه ينذر جيشاً بالكامل، لخوفه عليه من قرب الساعة، ولكي تأخذ الموعظة بتلابيب قلوبهم. وهذا ما أكده الإمام البيهقي . . في باب رفع الصوت بالخطبة، حيث أكد أن النبي

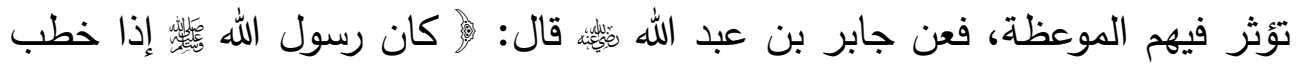
احمرت عيناه، وعلا صوته، واشتد غضبه حتى كأنه منذر جيش يقول صبحكم ومساكم ويقول بعثت أنا والساعة كهاتين ويفرق بين أصبعيه السبابة والوسطى ويقول: أما بعد فإن خير الحديث كتاب الله وخير الهدي هدي محمد، وشر الأمور محدثاتها

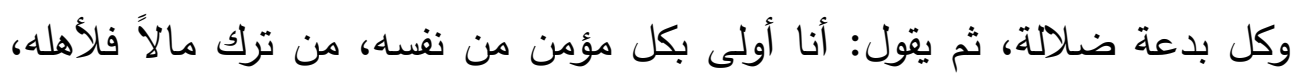

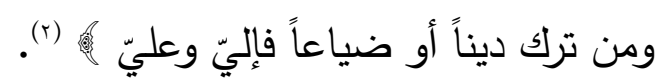
وعن عمران بن حصين أن رسول الله بل قال قال وهو في بعض أسفاره وقد

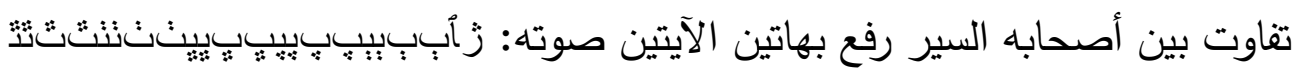

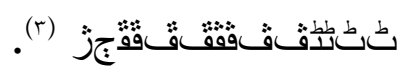

فالرحمة المهداة

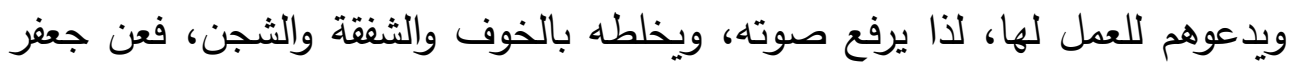

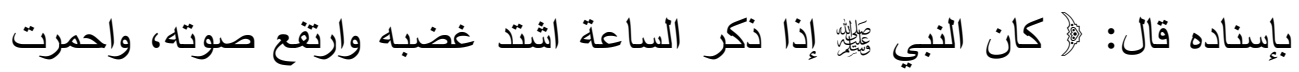

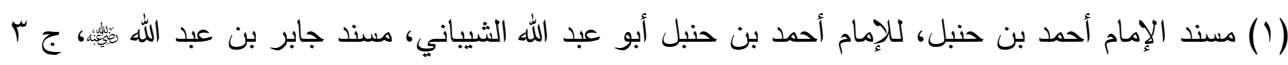

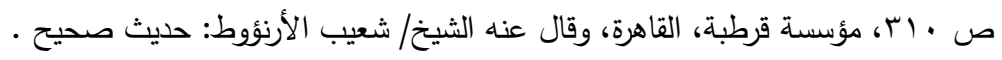

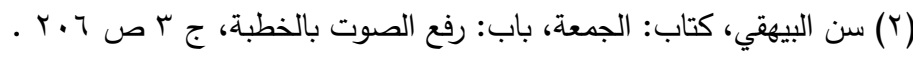

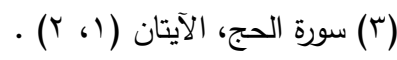


لغة الجسد بين الإسلام والدراسات التنموية البشرية و أثرها على المدعو

وجنتاه كأنه نذير جيش صبحكم ومساكم (1)

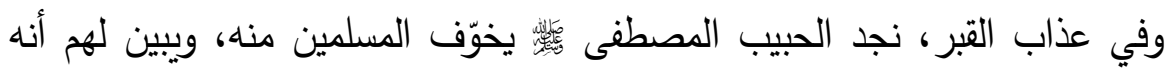
كقطع الليل المظلم، وأنه يستحق منهم التعوذ منه، وطلب الغوث من الله أن يقيهر عذابه، ويجدّوا للعمل لأول منزلٍ من منازل الدار الآخرة.

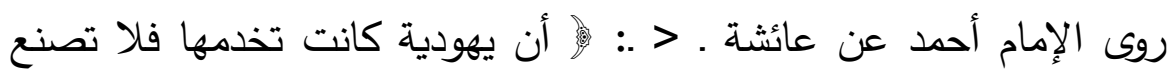

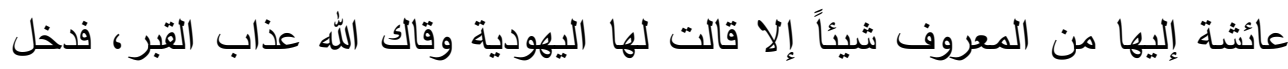
عليّ رسول الله

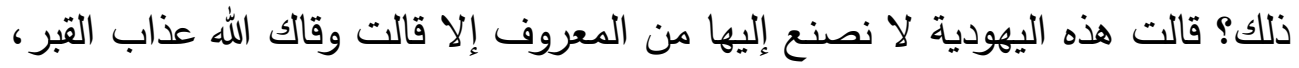

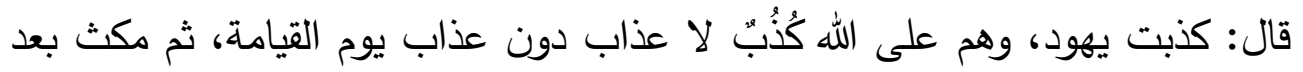

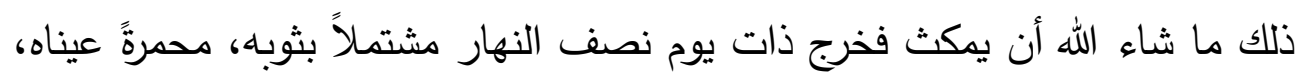

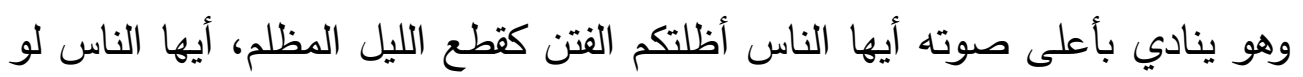

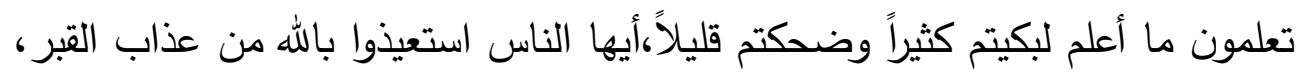

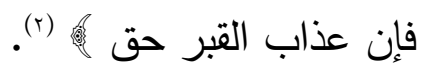

وفي الحديث عن النار، نجد نبرة النبي فئس تزداد حدةً للتخويف والإنذار، فعن

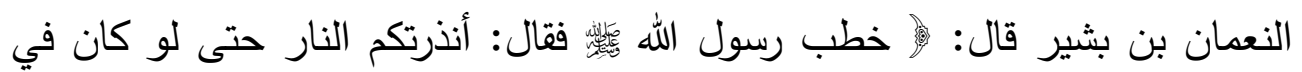
مقامي هذا لأسمع من في السوق حتى خرت خميصة كانت على عاتقه ) (r). فمن شدة الموعظة سقطت خميصة رسول الله على عنها، لأن الحديث فيه

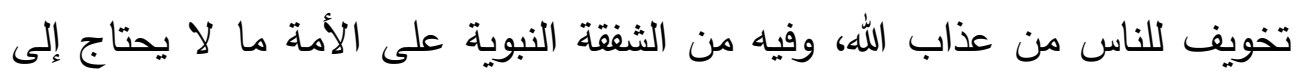
بيان، وهذا الموقف يستدعي رفع الصوت، وزيادة حدته، ليكون التأثير أبلغ.

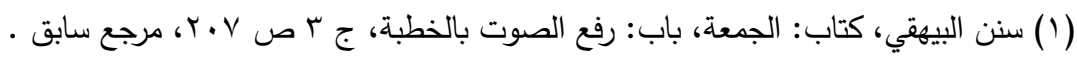

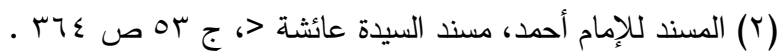

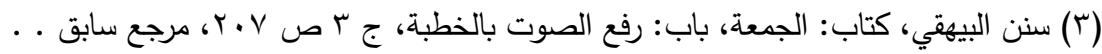

$$
\begin{aligned}
& -r q \mu-
\end{aligned}
$$


لغة الجسد بين الإسلام والدراسات التنموية البشرية و أثرها على المدعو

ومن أمثلة رفع نبرة الصوت في تقويم خطاًٍ بيّن لا يستدعي التأخير، ما رواه

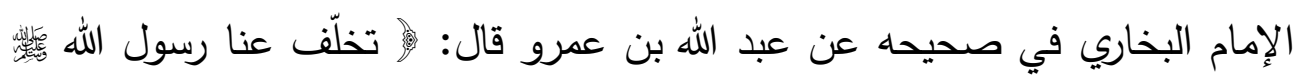
في سفرة سافرناها، فأدركنا وقد أرهقنا الصلاة، ونحن نتوضأ فجعلنا نمسح على على أرجلنا

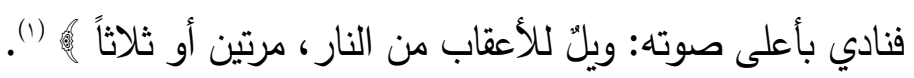

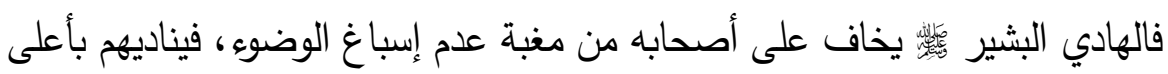

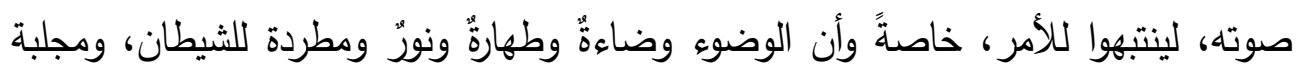

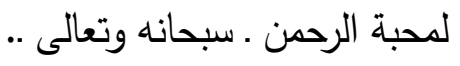

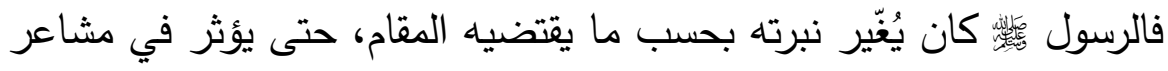

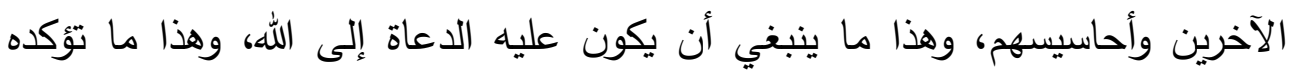

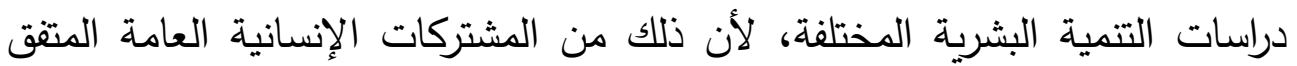
عليها.

ومن هنا يظهر خطأ بعض الدعاة والخطباء الذين يسيرون على وتيرة واحدة في الحديث فيشرد ذهن المستمع وينفر منه، ولا تتفاعل مشاعره مع ما يقوله، وهذاه لئل يعتبر جهل بفنون الدعوة إلى الله تعالى. وإليك أيها الداعي إلى الله بعض فنون استخدام الصوت حتى تؤثر في

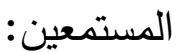

$$
\begin{aligned}
& \text { (1 ـ مطابقة الكلام والنبرة الصوتية للحديث (ترغيباً وترهيباً). } \\
& \text { r ـ التتوع في الصوت لا النمطية والاستمرار على أداءٍ واحد. } \\
& \text { r ـ موافقة الصوت للقلب. }
\end{aligned}
$$

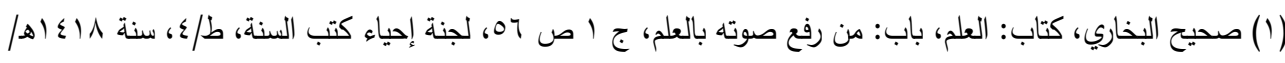


لغة الجسد بين الإسلام والدراسات التنموية البشرية وأثرها على المدعو

ع ـ الاعتناء بالأجهزة النقالة للصوت.

ه ـ الاعتدال في سرعة الصوت.

I ـ اجتتاب ما يضايق الحنجرة كأزرار الملابس.

V . الإعداد المسبق للصوت، كعدم الأكل أكثر من اللازم، أو شرب ماء بارد المدرد

جداً، وخلاف ذلك.

1 ـ التأني أثناء الكلام وعدم التسرع المذموم.

9 ـ تبيين الكلام وترتيله وترسيله.

• ا. الإقلال من النحنحة والكحة إلا لضرورة وتجنب عيوب النطق كالفأفأة والتأتأة

واللثغة وغيرها.

ويجب أن ننبه الدعاة إلى أن الاهتمام بنبرة الصوت أمرٌ درج عليه السابقون

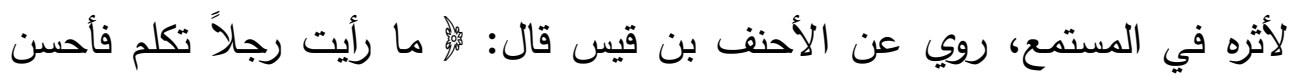
الوقوف عند مقاطع الكلام ولا عرف حدوده إلا عمرو بن العاص؛ كان إذا تكلم تقفد

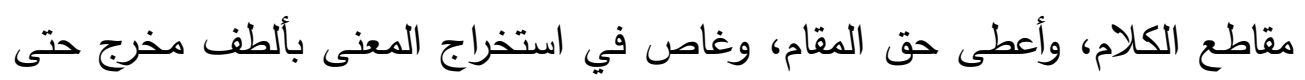

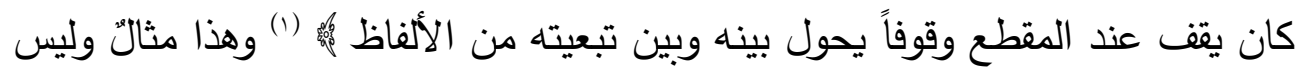
على سبيل الحصر . 
لغة الجسد بين الإسلام والدراسات التنموية البشرية و أثرها على المدعو

\section{الخاتمــة}

الحمد لله رب العالمين، والصلاة والسلام على أشرف الخلق والمرسلين سيدنا

$$
\text { محمد وعلى آله وصحبه وسلم.... وبعد؛؛؛ }
$$

بعد معايثة هذا البحث والخوض في أثبار أغواره وفقني الله لعدة نتائج

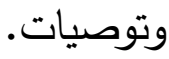

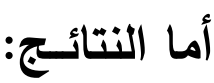

1 ـ ـ دراسة (لغة الجسد) أمرّ مهم جداً لوضع أيدي الدعاة على أحد المؤثرات المهمة التي

قد يفل البعض عنها.

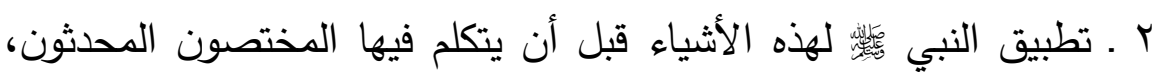

ليعطي دليلاً آخر على صدق النبي الكريم ـ صلوات ربي وسلامه عليه ..

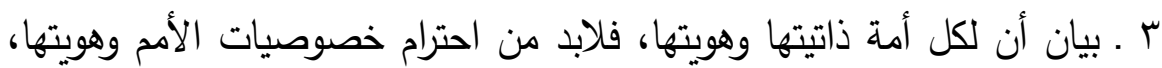

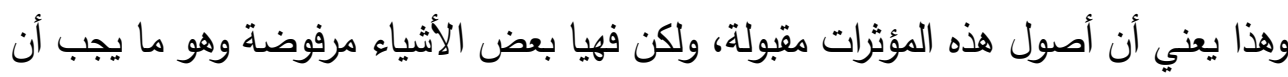

نعيه حتى تظهر شخصيتا وذاتيتا الرشيدة.

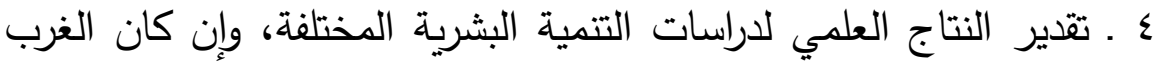

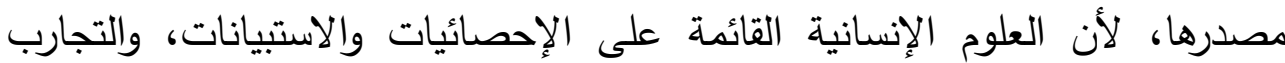

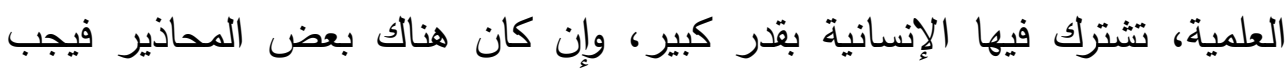

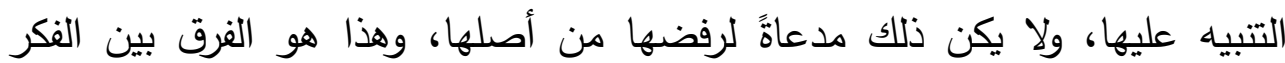
الوسطي والفكر المتثدد الذي لا يقبل الآخر .

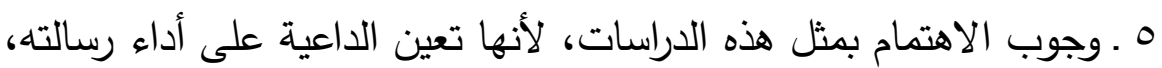

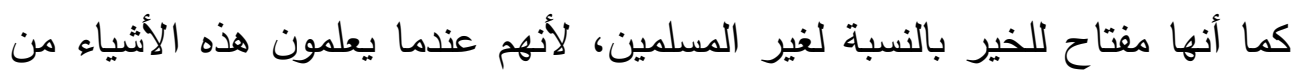

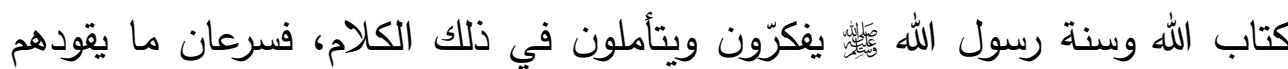

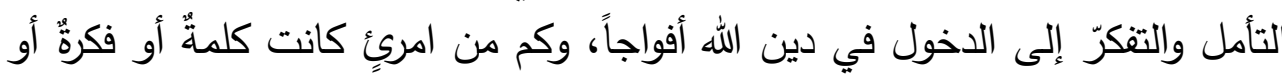

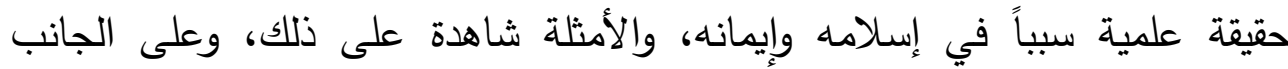


لغة الجسد بين الإسلام والدراسات التنموية البشرية و أثرها على المدعو

الآخر، إذا لم يسلم ويؤمن فإنه سيحترم ذلك الدين الذي يقدر الحقائق الإنسانية

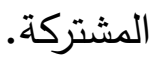

وأما التوصيات:

1 ـ فأوصي نفسي والباحثين بإتقان وفهم هذه الموضوعات وتطبيقها في حياتتا العملية، ولا تكون حبراً على ورق، أو مجرد دراسة نظرية لا تعدو إلى التطبيق.

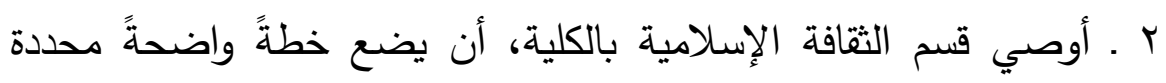

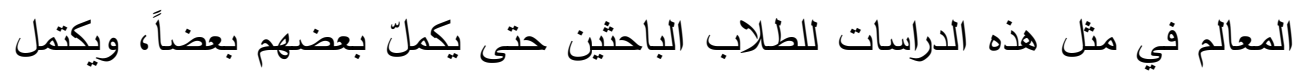
صرح البناء المعرفي ـ قدر الاستطاعة.

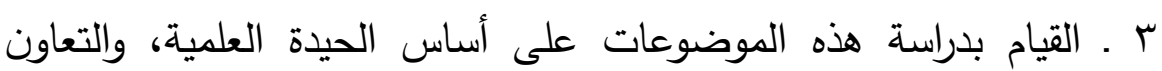

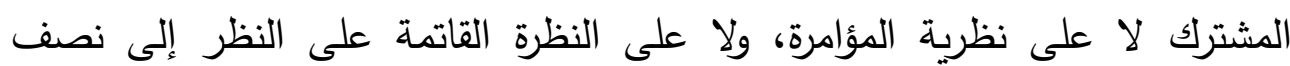

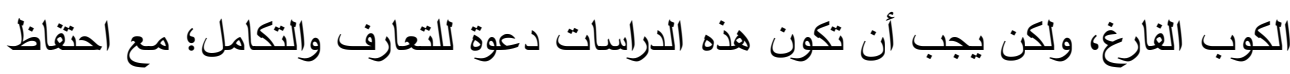
الأمم بخصوصياتها وهوياتها. وصلى الله وسلم وبارك على سيدنا محمد وعلى آله وصحبه وسلم ؛؛ د/ محمود رشاد محمد

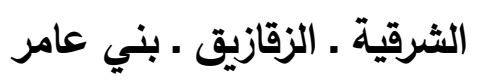


لغة الجسد بين الإسلام والدراسات التنموية البشرية و أثرها على المدعو

$$
\text { المصـادر والمراجـع }
$$

أولاً: القرآن الكريــم.

ثانياً: السنة النبويـة:

(1) سنن الترمذي، وهو الجامع الصحيح، مكتبة الرياض الحديثة، ط/ (، سنة

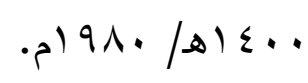

(Y) السنن الكبرى، للإمام الحافظ أبي بكر أحمد بن الحسين بن علي البيهقي،

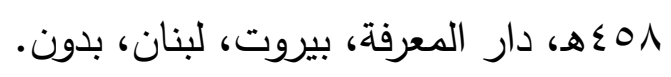

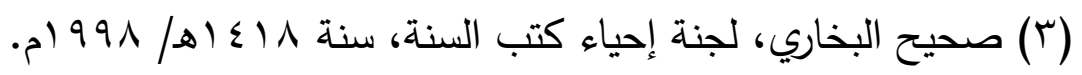

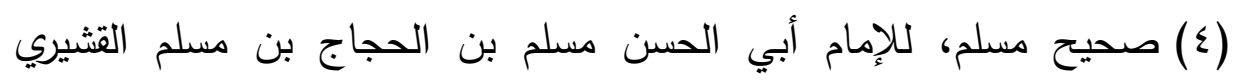

$$
\text { النيسابوري، دار الفكر ، بيروت، لبنان، بدون. }
$$

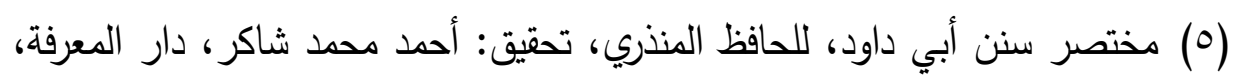

$$
\text { بيروت، لبنان، بدون. }
$$

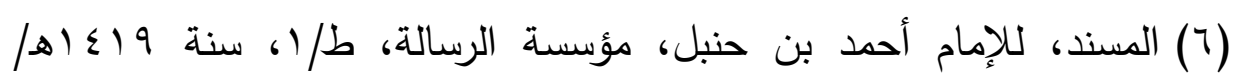

$$
\text { . } 1991
$$

(V)

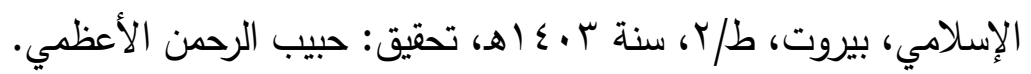

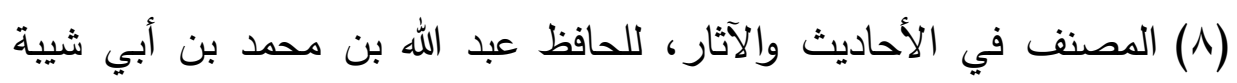

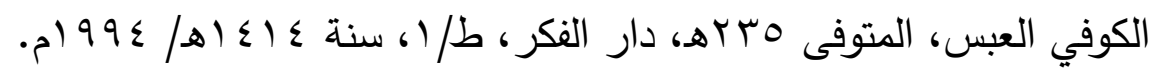

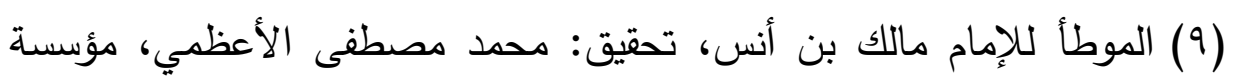

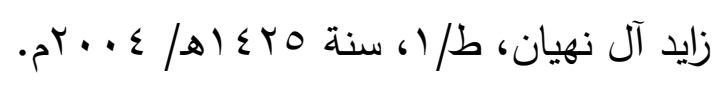

ثالثاً: شـروح الـقرآن: 
لغة الجسد بين الإسلام والدراسات التنموية البشرية و أثرها على المدعو

(1) تفسير الفخر الرازي، المشتهر بالتفسير الكبير ومفاتيح الغيب، للإمام محمد

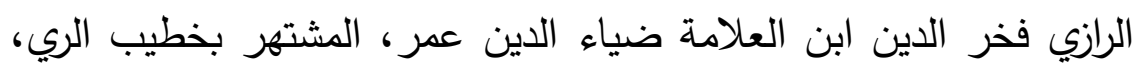

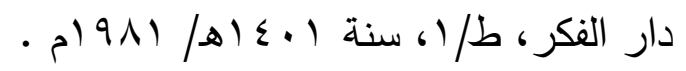

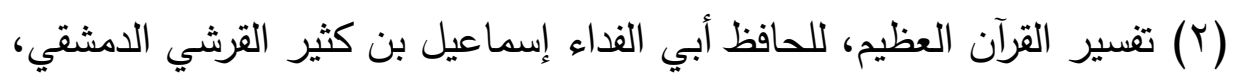

$$
\text { المجلد العربي،بدون. }
$$

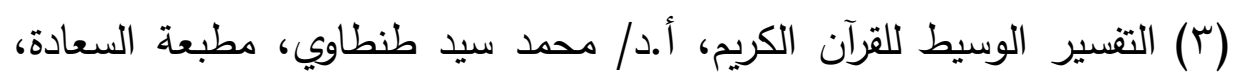

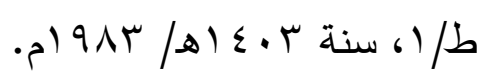

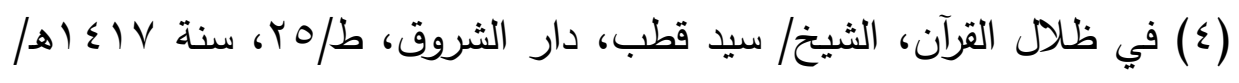

$$
\text { . } 1997
$$

(0) الكشاف عن حقائق التنزيل وعيون الأقاويل في وجوه التأويل، للإمام أبي

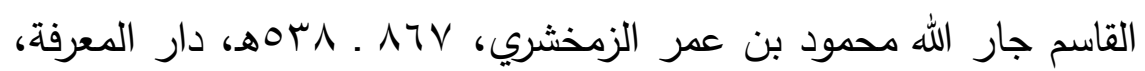

$$
\text { رابعاً: شروح السنــة }
$$$$
\text { (1) صحيح مسلم بشرح النووي، دار الكتب العلمية، بيروت، بدون. }
$$

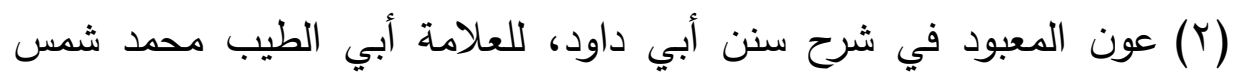

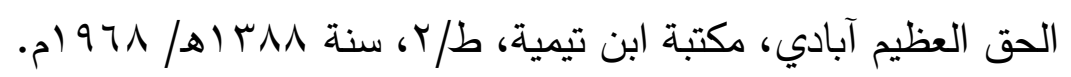


لغة الجسد بين الإسلام والدراسات التنموية البشرية و أثرها على المدعو

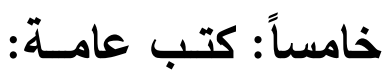

(1) أعمال كارنيجي المتعلقة بالثخصية الإيجابية، للباحث/ عادل هندي، كلية

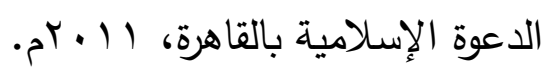

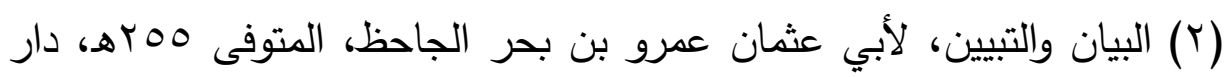
الكتب العلمية، بدون. - الكين.

(r) الخطابة علم وفن، د/ شرف الدين أحمد آدم، دار الحسين الإسلامية، ط/ با، سنة

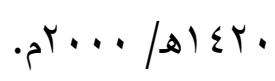

(§) الخطابة وإعداد الخطيب، إصدار وزارة الأوقاف المصرية، بدون.

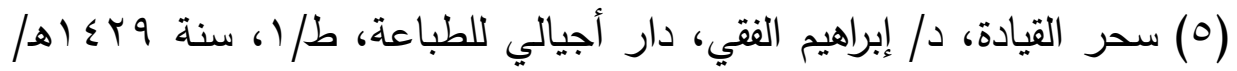

$$
\text { . . . } 19
$$

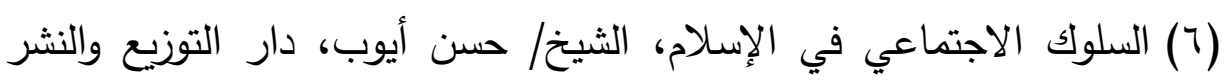

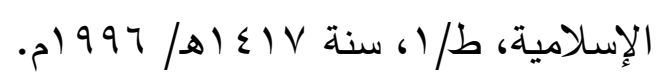

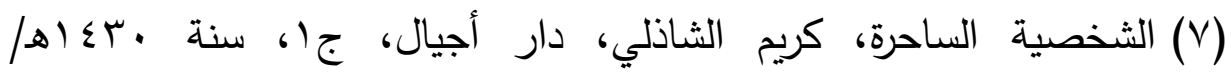

$$
\text { . } r \text { r. . } 9
$$

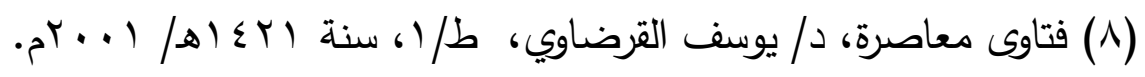

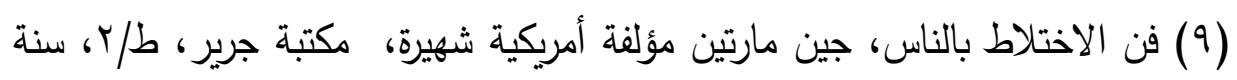

$$
\text { • ف }
$$

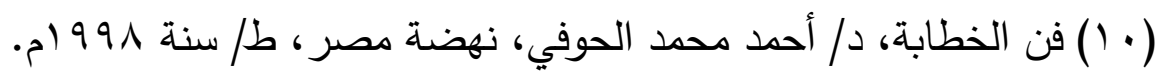

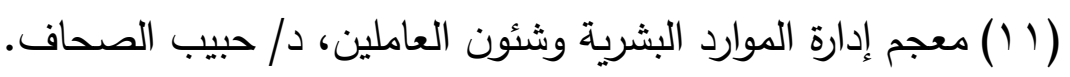


لغة الجسد بين الإسلام والدراسات التنموية البشرية و أثرها على المدعو

فهرس الموضوعــات

\begin{tabular}{|c|c|}
\hline 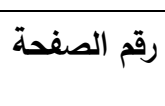 & الموضوع \\
\hline$r \leqslant 0$ & المقدمة ................................ \\
\hline$r \leqslant q$ & التمهيد ................................. \\
\hline rol & 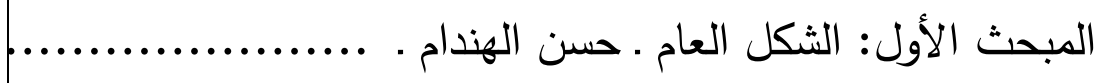 \\
\hline roo & 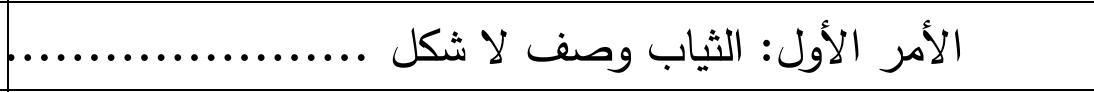 \\
\hline ros & 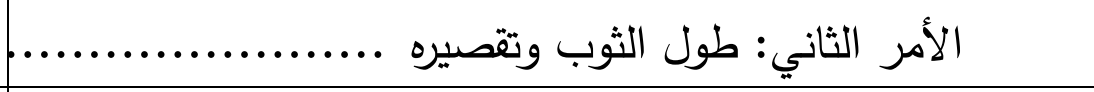 \\
\hline rT) & الأمر الثالث: تخصيص ثياب لمهنة معينة ................ \\
\hline 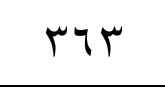 & المبحث الثاني: نظرات العين .......... \\
\hline$r v \cdot$ & المبحث الثالث: حركة الرأس ........... \\
\hline rVt & 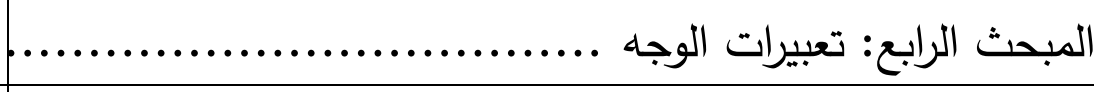 \\
\hline rAt & المبحث الخامس: الثغر البسام ( الابتسامة الجذابة) ............... \\
\hline r19 & المبحث السادس: الوقفة .............. \\
\hline rqs & 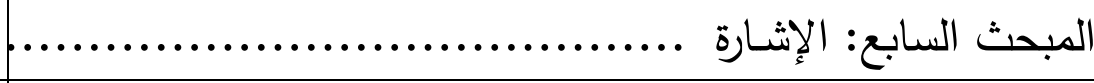 \\
\hline$\varepsilon+1$ & المبحث الثامن: نبرة الصوت ......... \\
\hline$\varepsilon \cdot 1$ & 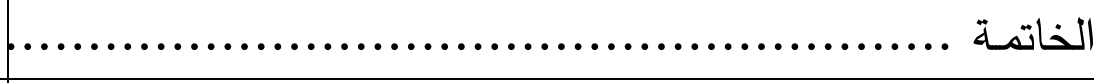 \\
\hline ¿ाr & 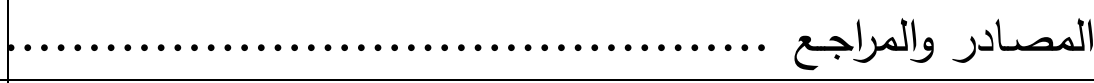 \\
\hline «10 & 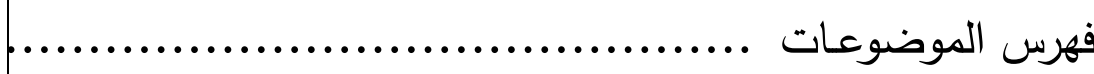 \\
\hline
\end{tabular}


$-\varepsilon \cdot r-$ 